Volume 112

Issue 1 Dickinson Law Review - Volume 112,

2007-2008

6-1-2007

\title{
Will the Post 9/11 World Be a Post-Tort World?
}

George W. Conk

Follow this and additional works at: https://ideas.dickinsonlaw.psu.edu/dlra

\section{Recommended Citation}

George W. Conk, Will the Post 9/11 World Be a Post-Tort World?, 112 Dick. L. ReV. 175 (2007).

Available at: https://ideas.dickinsonlaw.psu.edu/dlra/vol112/iss1/5

This Article is brought to you for free and open access by the Law Reviews at Dickinson Law IDEAS. It has been accepted for inclusion in Dickinson Law Review by an authorized editor of Dickinson Law IDEAS. For more information, please contact lja10@psu.edu. 


\section{Will the Post 9/11 World Be a Post-Tort World?}

\section{George W. Conk*}

\section{Table of Contents}

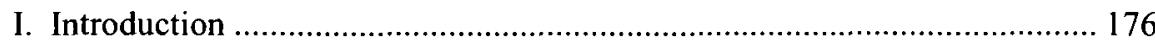

II. The Erosion and Persistence of Tort...................................................... 182

A. Legislative First Reaction-ATSSSA ................................................ 182

B. The Tort Alternative-Preserved .................................................... 188

C. But What Were the Realistic Prospects for Recovery in Tort Had There

Been no September 11 Fund? How Far Does Duty Extend? .............. 189

D. Will The 9/11 Victims Cases Go to Trial? ............................................... 191

III. Epidemic and Mass Tort Litigation at Ground Zero ............................ 198

A. Dust and Disease .......................................................................... 198

B. The Ground Zero Workers Respiratory Injury Tort Claims ..................... 202

C. Familiar Ground: New York Labor Law $\$ 241$ - Strict Liability for

Workers Doing Construction and Demolition Work.......................... 205

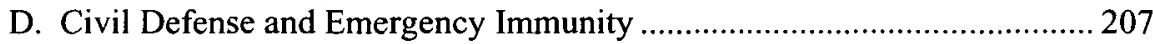

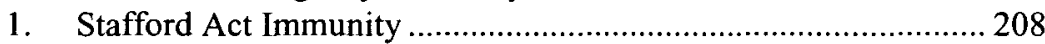

2. Defenses: Good Faith, Emergency and the SDEA ..................... 209

E. Aftermath of Judge Hellerstein's Decision to Allow the Ground Zero

Cases to Proceed: Special Masters-And an Expanded 9/11

Victims Fund? .............................................................................. 212

IV. The Second Wave_-Federal Immunity for Products .............................. 217

A. The Smallpox Emergency Personnel Protection Act ............................... 217

1. Liability Limitations and Compensation .................................... 218

* Adjunct Professor, Fordham Law School; Elected Member, American Law Institute; Member, ALI Consultative Group on the Restatement of Torts; Certified as a Civil Trial Attorney by the Supreme Court of New Jersey.

An earlier version on this paper was presented as the annual Raynes McCarty Distinguished Health Law Lecture, at the Union League, Philadelphia, and Widener Law School, October 11, 2006. Thanks are due to Raynes McCarty, P.C. and the Health Law Institute at Widener for their sponsorship, to John G. Culhane and Andrew Newman, Director and Associate Director of the Institute for the invitation, and to professors Jake Barnes, Jean Macchiaroli Eggen, and Anthony Sebok for reviewing an earlier draft.

Thanks are also owed to Denise A. Rubin, Esq., and to the Office of the Corporation Counsel, City of New York for providing me with briefs, transcripts, and other materials from the World Trade Center Disaster Site Litigation. 
2. The Impact of SEPPA on Tort Claims

221

B. The Public Readiness and Emergency Preparedness Act of 2005

C. Counterpoint to PREPA—S. 2291-The Responsible Public Readiness

and Emergency Preparedness Act

D. Whom Should We Compensate?

V. Historic Experience with Pandemic Flu Prophylaxis-The Swine Flu

Experience and the Federal Tort Claims Act

A. Swine Flu Vaccine Product Liability Claims

B. Hard Sell: The Federal Tort Claims Act-An Independent Basis for

Tort Liability of the United States Based on its Failure to Assure

Informed Consent.

C. Bad Blood in Britain: What Is a Citizen Entitled to Expect About

Drug, Vaccine and Biological Product Safety?

VI, Recap-A Regressive Trend

VII. Where Do We Go From Here? Civil Recourse and a Common Vision of Tort Law

\section{Introduction}

September 11, 2001 [9/11] changed everything, we are hyperbolically and tediously told. Beyond the lives of the dead, the injured, and their families, it created a general sense of emergency and alarm. 9/11 undermined our sense of insulation and of national security. It began a chain of reactions and overreactions.

The psychological, ${ }^{1}$ material, ${ }^{2}$ and political consequences of the attacks $^{3}$ have generated massive literature. Today we look at a small but important part of the story - the impact of $9 / 11$ on provisions for civil recourse by victims of harm. The security lapses were so patent that the airlines and aircraft makers were on Capitol Hill pleading for protection from negligence liability to victims on the ground within days of the catastrophic assaults on our financial center in New York and our military headquarters at the Pentagon. ${ }^{4}$ On November 19, 2001 Congress

1. Joel B. EISEN, The Trajectory of "Normal" after 9/11: Trauma, Recovery and Post-Traumatic Societal Adaptation, 14 FORDhAM ENVT'L L.J. 499 (2003) (discussing the complex and uncertain process of "post-traumatic societal adaptation").

2. GAO, RECENT ESTIMATES OF FISCAL IMPACT OF 2001 TERRORIST ATTACK ON NEW YORK, REPORT OF MARCH 30, 2005, GAO-05-269.

3. Mary L. Dudziak, ed., September 11 in History-A Watershed Moment? (Mary L. Dudziak ed.) (2003).

4. To preserve the continued viability of the United States air transportation system, and on the financial condition of the airline industry in the aftermath of the events which occurred on Tuesday, September 11, 2001: Hearing on H.R. 2891, Before the Committee on Transportation \& Infrastructure. (Regarding liability protection, the airlines are expected to propose that legislation be enacted to exempt the airlines' from liability for damage to persons and property on the ground. This proposal would not 
established the "September 11, 2001 Victims Compensation Fund," an elective remedy which required recipients to renounce any right of civil action for redress-except against the terrorists and their allies. It was the first of many restrictive measures embraced in Congress, with proponents citing $9 / 11$ as evidence of the need for immunities.

The short answer to the title question is: NO. Yet, tort law will continue to be eroded by attrition, by lopping off remedies - especially by limiting damages and expanding immunities - unless we are able to grab hold of the public's conscience and consciousness to bring home the point that liability in tort is not some form of punishment, erratically inflicted.

Rather tort law is a highly elaborated body of thought. It asks what constitutes socially unreasonable conduct and, by reasoned judgment, allocates liability, and assigns responsibility. Tort shares that public function with many institutions. But tort law is unique in that it is essentially private law. The parties are not the public, nor strangers to the controversy, but rather are the actors and victims themselves. As the system has evolved two key elements should be observed: tort law measures the conduct of all parties, allocating responsibility among them, and it gages conduct in context. What is socially required is determined, as we learn in the first semester of law school, by what constitutes reasonable care under the particular circumstances.

9/11 did not change everything. It affirmed much. The upsurge of public sympathy, the admiration for those who reported for duty as rescuers and lost their lives underlined the principle that individual recognition of the call of duty is the foundation of society. Underlying the law of torts is the principle of respect for the interests of others as equal to one's own. In the 1883 English case Heaven $v$. Pender ${ }^{5}$ a ship painter fell to the dock due to a faulty rope. Lord Brett expressed the concept of duty memorably:

whenever one person is by circumstances placed in such a position with regard to another that every one of ordinary sense who did think would at once recognize that if he did not use ordinary care and skill in his own conduct with regard to those circumstances he would

\footnotetext{
affect any existing rights of proper parties to bring claims against the airlines for all compensatory and punitive damages for the experiences and deaths of the airlines' passengers and crews), http://commdocs.house.gov/committees/Trans/hpw107-45.000/ hpw107-45_0f.htm, (last visited June 11, 2007). It is noteworthy that Hollis L. Harris, testified on behalf of the National Air Carriers Association that airlines carried adequate insurance for the loss of passengers, crew and planes. Their concerns centered on potential liability for persons and property on the ground.

5. Heaven v. Pender, Trading as West India Graving Dock Company, 11 Q.B.D. 503 (1883).
} 
cause danger of injury to the person or property of the other, a duty arises to use ordinary care and skill to avoid such danger. . . ${ }^{6}$

We look today at how that cloudless September day's terrible losses have played out in legal responses to $9 / 11$. Tort and compensation issues immediately rose to prominence. The early stages of the story are familiar. Shock and an outpouring of public sympathy and a desire to help those who suffered in the catastrophe brought a huge wave of charitable giving. Eleven days after the catastrophe came the first legislative response - the Air Transportation Safety and System Stabilization Act, (ATSSSA), which was quickly amended to add Title IV which creates the September 11 th Victim Compensation Fund of 2001. The Act created the Victims Compensation Fund for those who died or were injured that day at the disaster sites in New York, the Pentagon, and Pennsylvania and it brought liability protections for those whose breaches of duty may have enabled the crimes that stunned the nation and the world. ${ }^{8}$

At the site of the attacks in New York enormous effort followedfirst in the nearly fruitless search for survivors, then for the recovery of remains of the dead, and finally in removal of the debris of the fallen towers. In the wake of the catastrophe came labor, dust, and disease. We are witnessing the unfolding of an epidemic of industrial disease that evokes the historical epidemics of silicosis, ${ }^{9}$ asbestosis, and cancer. The stories of such epidemics are familiar. We learned them from such physicians as Irving J. Selikoff to whom we can still hope a Nobel prize in medicine will be posthumously awarded for his work in bringing an end to the heedless use of the miracle mineral-asbestos. ${ }^{10}$

Today we are learning of the epidemic of industrial illness at Ground Zero from Dr. Selikoff's successor at Mt. Sinai School of Medicine in New York. Dr. Philip Landrigan informed us in 2002 that the attack on the World Trade Center on September 11, 2001 was not only the worst assault on the American homeland in the 225-year history of the United States:

It was also the most massive acute environmental disaster that ever

6. $I d$.

7. Air Transportation Safety and System Stabilization Act, P.L. 107-42, 49 U.S.C. $\S$ A. 40101 (2006).

8. The point is to evoke the landmark article by Prof. Robert L. Rabin, Enabling Torts, 49 DePAUl L. REV. 435 (1999).

9. David Rosner and Gerald Markowitz, Deadly Dust: Silicosis and the POLITICS OF INDUSTRIAL DISEASE (1991).

10. Biological Effects of Asbestos, 132 annals of the New York ACAdemy of SCIENCES (Irving J. Selikoff, J. Churg, eds.) (1964); IRving J. SElikoff AND DOUGLAS K. LEE, ASBESTOS \& DisEASE (1978). 
has befallen New York City. The destruction of the twin towers released thousands of tons of toxic materials into the air of lower Manhattan-asbestos, particulate matter, lead, soot, PCBs, and dioxins. Workers and children were the groups at greatest risk of exposure. The threat to human health was compounded in the months after September 11 by the bioterrorist attacks involving anthrax.

Those two attacks-that of the suicide hijackers and the unknown authors of the criminal distribution of powdered anthrax through the mail-set the stage for the legislative responses that followed:

* the September 11 Victims Compensation Fund replaced tort liability claims for immediate victims of the catastrophe. The ATSSSA $\S 408$ limited to available insurance the liability of the airlines and the owners and operators of the airports through whose security measures the conspirators passed without difficulty, and the manufacturers of the aircraft the cockpits of which were so easily commandeered. ${ }^{12}$

* establishment of the World Trade Center Captive Insurance Company. It provides $\$ 1$ billion aggregate defense and excess liability insurance to the City of New York and its contractors. ${ }^{13}$ The City took control of the WTC site and hired over 100 companies to do the work of rescue, recovery, and debris removal. The City and its contractors are defending respiratory disease cases brought by thousands of policemen, firemen, and laborers who labored at Ground Zero.

* the smallpox vaccination campaign and the liability limitations and modest compensation scheme of the Smallpox Emergency Personnel Protection Act of $2003^{14}$

* the adoption of the government contractor defense for suppliers of "qualified anti-terrorism technology" to the newly created

11. Philip J. Landrigan, Lessons Learned: Worker Health and Safety Since September 11, 2001, 42 AMERICAN J. IND. MED. 530-31 (2002).

12. The 9/11 Commission Report, Final Report of the National Commission on Terrorist Attacks Upon the United States (2004), Chapter 1 "We Have Some Planes"; 49 U.S.C. $\S$ A. 40101.

13. 111 Stat. 517; WTC Captive Insurance Company, Inc., Liability Insurance Policy (Occurrence Basis) (on file with author); 49 U.S.C. 40101 (capping liability of City of New York at $\$ 350$ million or its insurance coverage, whichever is greater).

14. P.L. 108-20, $\S 2,117$ Stat. 638 ; codified at 42 U.S.C. $\S 239$, et seq. (2002); for a critical review of the campaign see INSTITUTE OF MEDICINE, COMMITTEE ON SMALLPOX Vaccination Program implementation, The Smallpox Vaccination ProgramPUblic HeALTH IN AN AGE OF TERrorism (2005). 
Department of Homeland Security in the SAFETY Act of $2004^{15}$

* the BioShield Act of 2004, which established a "strategic national stockpile" of "drugs, vaccines and other biological products, medical devices, and other supplies" for use in the event of bioterrorist attack or public health emergency. ${ }^{16}$

* the Public Readiness and Emergency Preparedness Act of 2005 (PREPA), which declares "targeted liability protections for pandemic and epidemic products and security countermeasures." PREPA abolishes tort liability except for cases of willful misconduct for the producers and providers of products which are declared by the Secretary of Health and Human Services to be potentially useful in emergency and are used in a period of declared emergency for the purposes described in the protective "declaration." Though it echoes the BioShield act, and describes its purposes as "targeted" liability measures for pandemics and epidemics, it is not limited to materials purchased for the "strategic stockpile" but rather extends its protections to any designated product and any administrator in any declared emergency. Its compensation provisions track those of the Smallpox Act. ${ }^{17}$

* S. 2291 , a bill introduced in the $109^{\text {th }}$ by the (then) Democratic Senate minority's leadership to repeal the PREPA. It would create a defense for a narrow class of medical products for which use is permitted without completing the usual regulatory vetting, due to their importance in a threatened emergency.

This article first discusses the ATSSSA. We review the strengths and weaknesses of the tort claims of those who were injured and died on 9/11. The greatest concern of the airline and aircraft industry was liability for persons and property on the ground, as was made clear in the Congressional hearings held eight days after the attack. Though there was fleeting reference to the allegedly wide variation in state common law provisions, the real concern was that the air carriers, reeling from the suspension of civil aviation and people's fear of flying, were not adequately insured for the losses on the ground. Such contingent liabilities were perceived as an obstacle to capital markets. ${ }^{18}$

15. Support Anti-terrorism by Fostering Effective Technologies Act, 2003, 6 U.S.C. 441, et seq. (2006).

16. 42 U.S.C. $\S 247(d)-(6)(b)(2006)$.

17. Public Readiness and Emergency Preparedness Act of 2005, P.L. 109-148, Div C, § 2, 119 Stat. 2818 (codified at 42 U.S.C. $\S 247 d-6 d$, et seq).

18. See September 19, 2001 hearings on H.R 2891, House Committee on Transportation and Infrastructure, supra note 4. 
The September 11 Fund was a pressure-release valve designed in significant part to relieve the distress of the air transportation industry. Without the Fund, the uncertainties, delays, and costs of the tort litigation against those whose inadequate security measures facilitated the crimes, and the unpalatability of making airlines, aircraft manufacturers, and airport operators bear the brunt of the cost of the tragedy might well have led to dismissal of the $9 / 11$ claims on grounds of lack of duty to the ground victims or unforeseeability as occurred in the cases of the Oklahoma City and the 1993 World Trade Center bombings. But leaving the ground victims without remedy would have been equally unpalatable, given the palpable sense of national unity and loss. Congressional action sooner or later was a likelihood. In the actual event, almost all ground victims accepted the 9/11 Fund awards. Those who did not elect to accept 9/11 Fund awards are so few that the available insurance appears to be adequate to satisfy any jury verdicts in favor of plaintiffs. Had all the ground victims joined in law suits with the passengers and others the available insurance and assets of the airline industry defendants might have been grossly insufficient had all the victims been left no other recourse. Such ruin is not threatened by the actions of those who spurned the Fund.

The opt-out claims have now been targeted for settlement by the trial judge. Judge Alvin K. Hellerstein has now scheduled six bellwether damages trials beginning September 2007. These trials will proceed while liability discovery continues. The cases are intended to set benchmark verdict values for victims of the $9 / 11$ attacks. ${ }^{19}$

Next reviewed are the WTC respiratory injury occupational disease tort claims, their necessity, and justice. We examine their vulnerability in light of the immunity and lack of duty defenses raised. The Ground Zero claims demonstrate the importance and vigor of the tort remedy. The other post 9/11 liability-limiting legislative measures are also

19. Order scheduling damages trials, $21 \mathrm{MC} 97$ (AKH), (S.D.N.Y. July 2, 2007) (This unusual procedure could produce low verdicts if, as trial lawyers' folklore predicts, larger verdicts follow demonstration of a defendant's fault. But according to a newspaper account at this essay went to press, other rulings such as allowing evidence of cockpit voice recordings on Flight 93 on which passengers struggled to the death with the hijackers, knowing of their intentions - impelled settlements. As of September 18 all but 21 cases had settled - for undisclosed amounts. It appears that all the ground victims have settled. All of the remaining open cases were claims by persons aboard the planes - whose claims were always the strongest - as analyzed above. See Amona Hartocollis, Settlements Do Not Deter 9/11 Plaintiffs Seeking Trial, NYTIMES.COM, September 19, 2007). 
discussed. They provide broad protection for many classes of actors and sellers, including administrators and producers of vaccines.

A survey of the historic experience with the Swine Flu vaccine campaign of 1976 shows the centrality of familiar tort liability principles of responsibility. In the Swine Flu vaccination campaign the federal government stood in the shoes of vaccine manufacturers. The United States admitted strict liability in tort for some vaccine complications (such as confirmed paralytic Guillain Barre Syndrome), and fought other claims. $^{20}$ Under the Federal Tort Claims Act the United States defended its own "hard sell" of the Swine Flu vaccine. But liability was imposed on the United States for the Centers for Disease Control's failure to adequately inform citizens of vaccine risks. ${ }^{21}$

The British Hepatitis C-contaminated blood cases are discussed as an instructive exemplar of government agency liability. There the National Blood Authority was held accountable as collector and distributor of blood products for its tardy implementation of an effective test for viral contamination of donated blood. ${ }^{22}$

The essay concludes with a call for a defense and revitalization of tort-embracing the vision of tort as civil recourse crafted by my Fordham colleague Benjamin Zipursky and his frequent collaborator John Goldberg of Vanderbilt.

\section{The Erosion and Persistence of Tort}

\section{A. Legislative First Reaction-ATSSA}

The first legislative reaction was the Air Transportation Safety and System Stabilization Act. ${ }^{23}$ The "September 11 th Victim Compensation Fund of 2001"24 was a legislative expression of the enormous outpouring of shock over the appalling attack and national sympathy for the victims of the suicide attackers. Potential tort action defendants had immediately sought to avoid liability for negligent operation of the security systems evaded by the hijackers, for defects in the design of the readily overcome cockpits, and for negligence in the management of the World Trade Center where evacuation plans and routes proved deeply flawed. ${ }^{25}$

20. See infra Section IV.A.

21. See infra Section IV.B.

22. See infra Section IV.B.

23. The Air Transportation Safety and System Stabilization Act is codified at 49

U.S.C. $\$ 40101$, et seq. (2006) [hereinafter ATSSSA].

24. 49 U.S.C. 40101 , section 401 , et seq. of the ATSSSA.

25. Robert L. Rabin, The Quest for Fairness in Compensating Victims of September 11, 49 Cleveland STATE L. Rev. 573-86 (2001); the claims ultimately brought are described by Judge Hellerstein in In Re September $11^{\text {th }}$ Litigation, $280 \mathrm{~F}$. Supp. 2d 
The ATSSSA was unique. It paired a financially unlimited hybrid no-fault social insurance fund with tort liability limitation measures: the United States would compensate the immediate victims of the attack ${ }^{26}$ on an individualized basis--in exchange for giving up the right to make tort claims (except against the attackers). ${ }^{27}$ And the Act limited the liability of the airlines, manufacturers, and airport operators.

Though driven by sympathy and the desire for quick closure for the families of the victims and the surviving injured victims themselves the Fund (itself without a budgetary limit) had limits common to the conventional tort reform agenda: ${ }^{28}$ collateral sources are credited against the claims, non-economic loss was capped at $\$ 250,000$ and $\$ 100,000$ additional provided for death claims. There was no cap on the aggregate payout. $\$ 7$ billion was paid in toto to 2,880 claimants whose family members died in the crashes or building collapses and to 2,680 persons who suffered physical injury at the Pentagon and the World Trade Center site. $^{29}$

A tort-like narrow definition of physical injury was adopted by the Special Master, Kenneth R. Feinberg, who enjoyed a unique status as master of an autonomous federal administrative agency. ${ }^{30}$ Only claims for bodily injury were recognized by Feinberg's office-and only for those claimants who were treated within 72 hours of injury or rescue. Thus those who suffered post-traumatic stress disorder without physical injury or whose physical conditions manifested ${ }^{31}$ later were excluded under the Final Rule. ${ }^{32}$

279, 288 (S.D.N.Y. 2003).

26. ATSSSA $\S 403$ afforded compensation "to any individual (or relatives of a deceased individual) who was physically injured or killed as a result of the terroristrelated aircraft crashes of September 11, 2001."

27. The Act provided for individualized, not categorical, damages for physical injury and death. Elements included medical expenses, wage loss, "non-economic losses" including "hedonic damages," and such damages as were permitted under state law (lex loci delicti) for wrongful death. See 49 U.S.C. $\$ 40101$, et seq.

28. Thomas F. Burke, Lawyers, Lawsuits, and Legal Rights-The Battle OVER LITIGATION IN AMERICAN SOCIETY (2002) (describing four basic forms of antilitigation efforts: discouragement, management, replacement, and resistance, and identifying workers compensation as the most significant of all anti-litigation reforms and the September 11 Fund as the latest replacement reform).

29. Final Report of the Special Master, September 11 Victim Compensation Fund of 2001 [hereinafter Final Report].

30. Matthew Diller, Tort and Social Welfare Principles in the Victim Compensation Fund, 53 DePaul L. REv. 719, 738 (2003) (victim compensation fund is a "marriage of tort and social welfare principles" which "grafts a system of private law remedies onto a program rooted in public law").

31. See, e.g. Metro North v. Buckley, 521 U.S. 424 (1997) (Common law experience teaches that fear of future cancer due to extensive inhalation of asbestos without symptomatic or objective physical injury is not a cognizable injury under FELA).

32. Final Rule, September 11 Victim Compensation Fund of 2001, 28 C.F.R. $\S 104$ 
No fixed non-economic loss awards were set for the physical injury claims, but awards in excess of $\$ 250,000$ were by administrative fiat reserved for "situations where a victim ultimately died after surviving for days, weeks or even months after the tragedy." 33

The Act provided for non-economic losses. ${ }^{34}$ Feinberg derived the minimum presumptive award of $\$ 250,000$ for each death from the statutory federal benefits paid to the families of soldiers, police, and firefighters who die in the line of duty. ${ }^{35}$ The Initial Final Rule guaranteed an additional $\$ 50,000$ for each dependent. ${ }^{36}$ In order to accomplish some leveling of awards Feinberg set and then adjusted categories of presumed economic and non-economic loss, doubling the initial proposed presumptive non-economic loss to $\$ 100,000$ for the spouse and each dependent, in addition to the presumed $\$ 250,000$ noneconomic loss for each death. Though this was not a cap the Special Master thought consistency important and required special circumstances be shown to depart from the norm. ${ }^{37}$

The Special Master too saw the Fund principally as a response by the nation to the trauma of the loss. But its tort-like provision for compensation for each individual claim was contentious. Death claims accounted for $\$ 5.99$ billion of the $\$ 7$ billion total claims paid. $43.5 \%$ of that went to claimants whose deceased victims earned under $\$ 100,000$. $30 \%$ went to families who had incomes in excess of $\$ 200,000 .^{38}$ The awards highlighted the distribution of wealth and income in our society and led to recriminations by some who asked why they whose husband or father, son, or daughter "died a hero" should receive a lesser award than a stockbroker's family. The top presumed economic loss was set at the $98^{\text {th }}$ percentile of household income $(\$ 231,000)$, which actually significantly lowered many awards. ${ }^{39}$ But the presumed awards were not true caps-each claimant was afforded the opportunity to be heard on

(2002) [hereinafter Final Rule].

33. Final Report supra note 29 , at 9.

34. ATSSSA $\S 402$ (9) defined non-economic broadly to include pain and suffering, disfigurement, impairment, mental anguish, loss of society and consortium, hedonic damages, injury to reputation and "all other nonpecuniary losses of any kind or nature."

35. Final Report, supra note 29, at 40.

36. Statement of the Special Master, September 11 th Victim Compensation Fund of 2001, 67 Fed. Reg. 11233 (March 13, 2002), 28 C.F.R. $\$ 104$ (2002).

37. 28 C.F.R. § 104.44 (2002) (The presumed non-economic losses for decedents shall be $\$ 250,000$ plus an additional $\$ 100,000$ for the spouse and each dependent of the deceased victim. Such presumed losses include a noneconomic component of replacement services loss).

38. Final Report, supra note 29, at 52-56, 96 (the latter number referencing Table 2, Distribution by Income).

39. Final Report, supra note 9, at 7-9. 
whether there should be a deviation from the presumed norm. ${ }^{40}$

The choices of the Special Master were understandable and prudent. But they were nonetheless controversial because there was no clear principle by which awards were determined, as George Priest ${ }^{41}$ and John Culhane have argued. ${ }^{42}$ The quest was not for full compensation tailored

40. 28 C.F.R. $\S 104.33$ (2002) (Hearings shall be before the Special Master or his designee. The objective of hearings shall be to permit the claimant to present information or evidence that the claimant believes is necessary to a full understanding of the claim. The claimant may request that the Special Master or his designee review any evidence relevant to the determination of the award, including without limitation: Factors and variables used in calculating economic loss; the identity of the victim's spouse and dependents; the financial needs of the claimant; facts affecting noneconomic loss; and any factual or legal arguments that the claimant contends should affect the award.).

41. George L. Priest, The Problematic Structure of the September 11th Victim Compensation Fund, 53 DePAul L. Rev. 527 (2003) ("Awards under tort law are constrained by the principle of awarding exactly the right amount. Recoveries under private market insurance are constrained by the principle that a beneficiary receives only what he or she has paid for. Benefits under government insurance or government welfare programs are constrained by general governmental budgetary limits. In contrast, there is no constraint on awards under the September 11 th Fund. Its budget is unlimited, and its definitional principles vague. It is, therefore, not surprising that many victim families have argued for larger awards. Finally, there is a second difference between awards under our society's four compensation systems and awards under the Fund that is worthy of notice. Our society's four compensation mechanisms are-in some formdemocratically defined. The common law derives from time immemorial; adjustments to it-say, by the enactment of survivor's and wrongful death statutes-have been made by democratically elected legislatures. Private market insurance is not democratic in a political sense, but it derives from citizen choices and bears the legitimacy of any allocation of resources determined under conditions of competition.").

42. John G. Culhane, What Does Justice Require for the Victims of Katrina and September 11? 10 DePaUl J. Health Care L. 177-79 (2007) (Although this impulse (to compensate) is understandable and perhaps even politically necessary, we should not settle for the results of such a "practical" approach. In earlier works, I have argued for separating the harms caused by social risks - those borne by everyone in a society, such as terrorism and contagious diseases-from harms resulting from what might broadly be called wrongful conduct... Such separation is necessary because justice imposes different requirements on compensation in the two cases. Inasmuch as social risks are those shared by all, compensating those who suffer harm from them is constrained by the requirements of distributive justice, which mandates that the needs and resources of the entire society be taken into account. On the other hand, when injury is caused by a private actor's fault-based conduct, the person harmed can call upon the full resources of the culpable party for compensation. A particularly dramatic example of what can happen when this division is insufficiently respected is the September 11 Victim Compensation Fund. Driven by the need to do something for those whose family members were killed by the tragic events of that day, Congress compensated those afflicted by the terrorist attacks almost as fully as though it was compensating tort victims. Payouts to aggrieved families went as high as $\$ 7$ million, and the overall cost to taxpayers-because the "fund" was such in name only-was just over $\$ 7$ billion. Singling out this class of victims for tort-like compensation served no principle of distributional fairness. Hurricane Katrina and its aftermath stand in stark contrast. Although the hurricane itself was not a preventable event, the devastation of New Orleans could have been averted had government on all levels not failed miserably in a host of ways: construction and maintenance of the levee system; 9 planning for evacuation; and 
to the individual case, nor to charge the full cost of the harm to the Fund in lieu of the absent defendant tortfeasor (as a tort award traditionally does under the common law rules of damages which ignore collateral sources). Rather there was a sense of rough equity, informed by tort and by legislative reference points (e.g. the use of the Public Service Officers Benefit as a marker for non-economic loss, and the $\$ 250,000$ statutory cap on non-economic loss in the National Childhood Vaccine Injury Compensation Program). ${ }^{43}$

The Act stipulated that awards for non-economic and for economic losses were subject to collateral source offsets. In fact total awards were reduced $\$ 2,915,027,850$ or $29 \%$ by collateral sources. ${ }^{44}$ This too led to dissatisfactions: some complained that the collateral source offsets mandated by the Act penalized those whose thrift benefited their families. 45 The Act defined collateral sources to mean "all" sources, including "including life insurance, pension funds, death benefit programs, and payments by Federal, State, or local governments related to the terrorist-related aircraft crashes of September 11, 2001."46 And there was the divisive issue of whether charitable donations were to be treated as collateral sources and deducted from proven losses (they were not). ${ }^{47}$

But consistent with the generous motivation he saw in the legislation, and using the unique administrative discretion he possessed, ${ }^{48}$ Feinberg, in the final rule took a generous approach to the collateral source deductions from demonstrable loss. All did not mean all. The Special Master excluded life insurance proceeds that were distributed to persons other than the beneficiaries of the Fund; used his discretion to adjust the amount of offsets to exclude premiums or assets that were

communication and rapid-response efforts once evacuation became necessary. Yet the federal government has come up with no compensation system on the order of the Victim Compensation Fund, even though the federal government's fault is clear and perhaps even conceded in this case.).

43. National Childhood Vaccine Injury Act of 1986, P.L. 99-660 42 U.S.C. $\S 300$ (aa)-10, et seq. (2002).

44. Final Report, supra note 29 , at 9.

45. Id. at 10-13.

46. ATSSSA § $402(6)$.

47. See Final Report of Special Master, supra note 29.

48. Diller, supra note 30 , at 767 (Feinberg's conduct highlights the central weakness of the Fund as an administrative mechanism-its operation rests on the personal choices of a single individual, with little means of accountability or oversight. As Feinberg has construed his grant of authority, there are few governing legal standards, no real requirement that claims be treated alike, no obligation to provide reasoned explanations, no limits on the amount that may be spent, and no means of judicial review. It is difficult to conclude that the Fund constitutes a responsible administrative mechanism for dispensing billions in public funds however wise and solomonic Feinberg's judgments may be.). 
accumulated by the victim through self-contributions paid into a life insurance program to build up a tax-deferred cash value; and reduced the amount of the offset for a pension to take account of self-contributions to that plan over the decedent's lifetime. ${ }^{49}$ In addition, the final rule provided that tax benefits received from the federal government as a result of the enactment of the Victims of Terrorism Tax Relief Act of 2001 would not be treated as collateral source compensation. ${ }^{50}$

In the end, the average award was $\$ 1,000,000$-and that was completed far faster than tort litigation would have delivered that result. ${ }^{51}$ And far more cheaply because it was not only a non-adversarial process but the bulk of the lawyers who handled the claims did so without fee through the Trial Lawyers Care program. ${ }^{52}$ Even those who handled the case for a fee took reduced fees which were examined carefully by courts. $^{53}$ And, it bears noting, the Special Master and his law firm worked 19,000 hours without fee. ${ }^{54}$

Because filing of a fund claim constituted waiver of the right to sue the airlines, aircraft manufacturers, or airport operators and sponsors, ${ }^{55}$ the September 11 Fund was discussed, especially at the time of passage, as a way of saving the airlines, manufacturers, and airport operators from crushing liability arising from inadequate cockpit security design and poor airport screening. But such problems could have been addressed by liability caps, or by limiting claims to existing insurance policy limits. It seems likely then that the driving force behind the fund was our tidal wave of sympathy, the desire to see victims' and their families' needs met with dispatch, rather than be subjected to the delays and

49. 28 C.F.R. $\$ 104.47$ (2002).

50. Final Rule, Statement by the Special Master, 67 Fed. Reg 11233, 11241 (March 13, 2002) ("The Victims of Terrorism Tax Relief Act of 2001 [P.L. 107-134] provides income and estate tax relief to the families of victims of terrorism. ... [I]t waives the income tax liability of a victim who died in one of the attacks for both the year of the attack and the previous year, and ensures that a minimum benefit of $\$ 10,000$ is provided to the family of each victim ... that relief will not be treated as collateral source compensation for purposes of determining awards from the Fund.").

51. The final deadline for submission of claims was December 23, 2003. Claims were processed quickly and the Final Report of the Special Master issued in November 2004.

52. See The association of Trial LAwyers of AMERICA, Thousands of Heroes-The Rest of Us COULd ONLy Help, REPORT to CONGRess (2004) available at http://www.atla.org/homepage/TLC.aspx (describing the work of ATLA's Trial Lawyers Care project and 1,100 attorneys' pro bono work on behalf of 1,700 families).

53. See, e.g. Estate of Gomez, 785 N.Y.S.2d 866 (2004) (The Bronx County Surrogate carefully scrutinized fee applications and required submission of detailed affidavits of service of contingent fees ranging from zero to $10 \%$.).

54. Final Report, supra note 29, at 114 .

55. ATSSSA $\S 405(\mathrm{c})(3)(\mathrm{B})(\mathrm{I})$. 
uncertainties of litigation, as Professor Robert Rabin has suggested. ${ }^{56}$

\section{B. The Tort Alternative-Preserved}

If Congress had not created the September 11 Fund and the families of the victims were dependent on pending tort litigation, and the aviation defendants and their insurers were bearing the full burden of litigation and satisfaction of any judgments public sentiment would have put enormous pressure on the litigants and the court. It is not possible to say how the courts would have responded under the klieg lights that would have been on every aspect of the cases. But ordinary experience tells us that systems break under great pressure.

The compensatory purpose of the September 11 Fund seems to have been well served. But compared to what? It appears on the surface that United and American airlines, the aircraft manufacturer Boeing, and the airport security companies and operators have saved $\$ 6$ billion. Perhaps more-given that one can readily imagine huge pain and suffering awards-especially for those at or above the points of impact of the jets, where many jumped to their deaths to escape the inferno.

Congress preserved an optional tort remedy. It created an exclusive federal tort cause of action for all damages claims arising from the September 11 hijackings with the substantive law (including choices of law) drawn from the law of New York or other crash locations (except to the extent "inconsistent with or preempted" by federal law), limited recoveries to insurance available, ${ }^{57}$ and set venue in the United States District Court for the Southern District of New York. ${ }^{58}$ Seventy who declined to make claims to the Fund and ten businesses have filed suit there. The actions are pending before Judge Alvin K. Hellerstein, who has taken on the monumental job of managing the September 11 litigation. Cases involving claims arising out of, resulting from, or

56. Rabin, Cleveland STATE, supra 25, at 576 (There is no reason to think that members of Congress, who endorsed the Fund with acclaim just two weeks after the event, at the high tide of emotional response to September 11, were immune to these sentiments. In short, the Fund was created under singular circumstances. Rather than reflecting a political trade-off designed to quell workplace unrest (black lung, workers' compensation), or to provide liability assurances to an industry (vaccine, PriceAnderson), the Fund was conceived at least in part as a grant of largess to the survivors of those who had unwittingly served as surrogates, stand-ins, for the rest of the American people.).

57. The liability of New York City was limited to available insurance or $\$ 350,000,000$, whichever is greater. Through the Captive Insurance Company there is $\$ 1,000,000$ available to the City and its contractors, which coverage is above the Lloyds' coverage for the Ground Zero workers' claims. See Captive Insurance Policy, infra note 122.

58. ATSSSA $\S 408(\mathrm{~b})$. 
relating to the terrorist-related aircraft crashes of September 11, 2001 and naming as defendants an airline, an airport security company, and/or The Port Authority of New York and New Jersey have been consolidated for discovery and other pre-trial proceedings before Judge Hellerstein. They include: (i) In re September 11 Litigation, 21 MC 97 (AKH), claims brought by passengers and ground victims of the September 11 attacks; (ii) In re September 11 Litigation, $21 \mathrm{MC} 101$ (AKH), claims brought by property owners whose property was damaged as a result of the September 11 attacks; (iii) In re World Trade Center Disaster Site Litigation, $21 \mathrm{MC} 100$ (AKH), claims brought by those who came to the World Trade Center disaster site to assist with the debris removal effort following the September 11 attacks; (iv) In re World Trade Center Disaster Site Litigation, 21 MC 102 (AKH), claims brought by those who assisted with the debris removal effort at sites other than the WTC site following the September 11 attacks.

\section{What Were the Realistic Prospects for Recovery in Tort Had There Been No September 11 Fund? How Far Does Duty Extend?}

Would the 9/11 plaintiffs have met the same fate as the claims of victims of the 1995 Oklahoma City bombing who sued the manufacturers of the fertilizers weaponized by Timothy McVeigh? The question is particularly acute for the ground victims-because their victimization was a more remote contingency than was the death of a passenger on a hijacked airplane. The Oklahoma City victims and families, like the Port Authority as landowner in the 1993 World Trade Center bombing cases, brought product liability cases against the manufacturers of the ammonium nitrate used in the truck bombs. The plaintiffs alleged a design defect in the "explosive grade" fertilizer used by McVeigh. The Oklahoma claims were dismissed as a matter of law by the $10^{\text {th }}$ Circuit in Gaines v. ICI, as the court held that the plaintiffs could not establish proximate cause. ${ }^{59}$ In doing this, the Court of Appeals relied on the Restatement of Torts, 2d. Its black letter rule declares the criminal act of a third person to be a superseding cause unless the defendant had reason to foresee the criminal act:

The act of a third person in committing an intentional tort or crime is a superseding cause of harm to another resulting therefrom, although the actor's negligent conduct created a situation which afforded an opportunity to the third person to commit such a tort or crime, unless the actor at the time of his negligent conduct realized or should have realized the likelihood that such a situation might be created, and

59. Gaines v. ICI, 160 F.3d 613 (10th Cir. 1998). 
that a third person might avail himself of the opportunity to commit such a tort or crime. ${ }^{60}$

The $10^{\text {th }}$ Circuit Court of Appeals noted particularly Comment $b$. of $\S 448$, which discusses:

situations which are commonly recognized as affording temptations to which a recognizable percentage of humanity is likely to yield. So too, there are situations which create temptations to which no considerable percentage of ordinary mankind is likely to yield but which, if they are created at a place where persons of peculiarly vicious type are likely to be, should be recognized as likely to lead to the commission of fairly definite types of crime. ${ }^{61}$

But the precursors pointed to by plaintiffs as signals of foreseeable risk-the bombing of the Army Mathematics Research Center in Madison, Wisconsin by an anti-war extremist in 1970, and the attacks by the IRA and other guerillas in the U.K. and Europe-were found by the Court of Appeals to be too remote from "the test of common experience" to be a proximate cause. ${ }^{62}$ The $10^{\text {th }}$ Circuit treated the victims in the Alfred P. Murrah Federal Building like Mrs. Bolton who unfortunately stepped outside her house at the moment a slugger at the cricket pitch across the lane launched a rare long ball, injuring her seriously. Mrs. Bolton was the blameless victim of an event so unlikely to cause injury that no liability was found by the House of Lords in the tort law classic Bolton v. Stone. ${ }^{63}$ The Oklahoma City case was barred, said the Court of Appeals, by the Restatement of Torts, 2d, $\S 302 \mathrm{~B}$, which states "Even where there is a recognizable possibility of the intentional interference, the possibility may be so slight, or there may be so slight a risk of foreseeable harm to another as a result of the interference, that a reasonable man in the position of the actor would disregard it."64

A similar conclusion, more conventionally and securely grounded in the concept of duty, was reached 10 months later by the Third Circuit in an action by the Port Authority of New York \& New Jersey against the manufacturers of the ingredients in the 1993 truck bombing of the World Trade Center. Like the Oklahoma City defendants, the defendant manufacturers sued by the Port Authority, the Port Authority moved under F.R.C.P. 12(b)(6) to dismiss for failure to state a cause of action. In Port Authority v. Arcadian, the court accepted arguendo the allegations in the complaint--that ammonium nitrate prills could be

60. RESTATEMENT (SECOND) OF TORTS $\S 448$ (1977). (Emph. added)

61. Gaines v. ICI, 160 F.3d at 620-21.

62. Id. at 620 .

63. Bolton v. Stone, [1951] A.C. 850.

64. Restatement (SECOND) OF TORTS § 302B, cmt. D (1977). 
rendered non-detonable, and that European manufacturers were required by law to render their ammonium nitrate products non-detonable. The American manufacturers' failure to do so was alleged to render their products defective. $^{65}$

The U.S. Court of Appeals in Philadelphia, finding no significant differences between the law of New York and that of New Jersey-the locale of the rental of the truck and the assembly of the bomb-held that the fertilizer manufacturer had "no duty to prevent a criminal misuse of their products which is entirely foreign to the purpose for which the product was intended." Even if the misuse of the product was foreseeable it was not an "objectively foreseeable" alteration and no duty arose on the part of the manufacturer, according to the majority. ${ }^{66}$

But Circuit Judge Hoeveler, while concurring, declared in a separate opinion

I am, however, constrained to offer an observation which may bear the fruit of protection from further similar disasters. The precedential value of our decision, as well as that of the Tenth Circuit in GainesTabb v. ICI Explosives, USA, Inc., 160 F.3d 613 (10th Cir. 1998), rests largely on a slender and temporal reed: lack of foreseeability of the intervening criminal act. Whether experience and failure to use available safeguards will, in time, create new legal duties on the part of the manufacturer remains to be seen. We live in a society in which the disgruntled more and more resort to violence. Appellees' products, so easily convertible to dangerous qualities, need not-with proper treatment - become a part of that violence. ${ }^{67}$

So far that slender and temporal reed has not barred the actions of those who declined the opportunity to take the ATSSSA's $\S 405$ no-fault benefits, but rather elected the tort option.

\section{Will the 9/11 Victims Cases Go to Trial?}

The few (about seventy) who declined to make claims from the victims' compensation fund have sought relief in a traditional tort remedy with trial by jury. Their complaints alleged that United and American airlines, airport security companies, and airport operators failed to fulfill their security responsibilities. The Port Authority is

65. Port Auth. v. Arcadian, 189 F.3d 305 (3rd Cir. 1999).

66. Id. at 314-15.

67. Id. at 321 (emphasis added). It is not clear that plaintiffs' (and Judge Hoeveler) were correct regarding the technology. A later report by the National Academy of Sciences found substantial doubt about the technology to render ammonium nitrate nondetonable. National Research Council, Containing the Threat from Illegal BOMBING (1998). 
alleged to have negligently constructed, designed, and managed the buildings, and to have failed, even after the 1993 truck bombing, to provide safe evacuation routes and plans. Boeing, the manufacturer of the commandeered aircraft is alleged to have defectively designed the cockpit doors because they were not designed to prevent forced entry. ${ }^{68}$

Judge Hellerstein rejected the aviation defendants' F.R.C.P. 12(b)(6) motions to dismiss for failure to state a cause of action. ${ }^{69}$ His comprehensive opinion rejected the aviation defendants' argument that they owed no duty to the ground victims and others because it was "beyond the scope of any foreseeable duty owed.",

But subsequent developments in the law of duty in New York cast doubt on whether Hellerstein's prediction that New York law extending duty to the ground victims and passengers will withstand appeal if the cases are not settled. ATSSSA $\S 408$ makes New York law the substantive law of the WTC tort claims. ${ }^{71}$ Judge Hellerstein, quoting the 1987 New York Court of Appeals decision in D'Amico v. Christie, ${ }^{72}$ correctly notes that New York has been "cautious in extending liability to defendants for their failure to control the conduct of others "even where as a practical matter [the] defendant can exercise such control.",73 Such an attitude by the New York high court may yet doom the claims of the ground victims.

This conservative stance on the imposition of a duty is vigorously embraced again by the New York Court of Appeals in the 2005 case Holdampf v. Port Authority. ${ }^{74}$ The New York high court's decision contrasts with the thinking of the New Jersey Supreme Court in the 2005 case Olivo v. Exxon. ${ }^{75}$ In each case a worker's wife developed the lethal asbestos-related cancer mesothelioma from laundering her husband's asbestos dust-laden work clothing. The New Jersey Supreme Court allowed the claim. It noted that as early as 1916 industrial hygienists had warned of the dangers of bringing asbestos contaminants home in work

68. In Re World Trade Center Litigation, 280 F. Supp. 2d 279, 289 (S.D.N.Y. 2003).

69. Id. (Among the plaintiffs are ten businesses that sustained property damage. Hellerstein also rejected the Port Authority's motion to dismiss.). Plaintiffs alleged that fire suppression and escape systems at the World Trade Center were negligently designed and operated. Id. at 302-06.

70. Id. at $290-94$.

71. 49 U.S.C. $\S 40101$ (2002).

72. D'Amico v. Christie, 71 N.Y.2d 76 (N.Y. 1987) (stating that employer did not owe duty to victim of intoxicated employee who had been ordered to leave premises and then drove car while intoxicated).

73. Id.

74. Holdampf v. AC\&S and Port Auth., 5 N.Y.3d 486 (2005) (citing Hamilton v. Beretta, 96 N.Y.2d $222(2001))$.

75. Olivo v. Owens-Illinois, Inc., 186 N.J. 394 (N.J. 2006). 
clothing. The Jersey justices declared "the duty we recognize in these circumstances is focused on the particularized foreseeability of harm to plaintiff's wife, who ordinarily would perform typical household chores that would include laundering the work clothes worn by her husband." ${ }^{, 76}$

But the New York high court, citing Palsgraf v. LIRR Co., ${ }^{77}$ declared foreseeability to be relevant only if it found a duty of care was owed. The New York court found none, overturned the decisions below and dismissec the case. ${ }^{78}$ The Port Authority, whether as employer or land owner, had no duty because it had no special relationship with its employee's wife. ${ }^{79}$ The court feared creating "limitless liability to an indeterminate class of persons conceivably injured" by imposing a duty on employers for negligent acts toward such a person as the spouse of an employee. $^{80}$ Citing its refusal to impose liability on gun sellers for criminal acts by remote gun owners the New York high court emphasized that "any extension of the scope of duty must be tailored to reflect accurately the extent that its social benefits outweigh its costs."

If the federal court of Appeals in New York faced the question on appeal from Judge Hellerstein's courtroom, the circuit judges might well decide that New York would conclude that the costs outweighed the social benefits of imposing a duty on the airlines and aircraft manufacturers to control the actions of the terrorists. If no September 11 Fund had been established there are significant doubts that the tort claims would have survived appeal and doubt that settlements (or awards paid) would even have equaled what the Special Master doled out.

The September 11 Fund paid out $\$ 7$ billion in three years. ${ }^{82}$ The rough guess liability insurance exposure for the seventy $9 / 11$ plaintiffsbased on average payouts of $\$ 2-4$ million per claim in commercial aviation accidents - is estimated to be $\$ 3.5$ billion for United and American Airlines and $\$ 4$ billion for other aviation defendants, according to a Rand Institute report. ${ }^{83}$ If Congress had not enacted the ATSSSA bankruptcy filings might have limited the litigation to the proceeds of the available insurance, which may well have created pressures on Congress to then enact something like the September 11 fund. It takes little imagination to look back to the future to say that national sentiment for

\footnotetext{
76. Id. 404 .

77. Palsgraf v. LIRR Co., 162 N.E. 99 (N.Y. 1928).

78. See Holdampf, 5 N.Y.3d at 498.

79. See id.

80. Id. at 493 .

81. Id.

82. Final Report, supra note 29, at 1.

83. Lloyd Dixon and Rachel Kaganoff Stern, The Rand Institute for civil Justice, Compensation for Losses from the 9/11 Attacks, Rand Institute for Civil Justice 59-60
} (2004). 
the bereaved families of the $9 / 11$ victims would have been impatient with the glacial pace of litigation. Of course charitable outpouring was great, but such sentiment also invites action by elected officials. And the claims of these particular widows and orphans, languishing in litigation, the stuff of tabloid headlines and evening news profiles and laments, would certainly have invited action by elected representatives. In the actual event, Congress did place limits on the claims of $9 / 11$ victims. ATSSSA $\S 408$ limited recovery to insurance in place on September 11 , 2001 "for all claims, whether for compensatory or punitive damages or for contribution or indemnity, arising from the terrorist-related aircraft crashes of September 11, 2001, against an air carrier, aircraft manufacturer, airport sponsor, or person [with a property interest in the World Trade Center]." 84

The relative handful of 9/11 Fund opt-out cases are now headed to trial and jury verdict-as did the 1993 World Trade Center Bombing cases against the Port Authority which came to trial in $2005 .^{85}$ The New York Supreme Court allowed the lawsuits by those who in 1993 suffered physical and economic injury to proceed against the Port Authority. The Port Authority of New York and New Jersey as landlord did not have governmental immunity under the act creating the bi-state agency. ${ }^{86}$ Relying on New York precedent, Justice Stanley L. Sklar ruled that "[w]here ambient crime has infiltrated a landlord's premises, or where the landlord is otherwise on notice of a serious risk of such infiltration, the landlord's duty to protect arises." The trial judge found "[t]he predicted scenario, eerily accurate, in the Port Authority's (pre-1993 bombing) security reports, of a vehicle bomb in the garage, and the evidence of bomb threats in the complex, [is] sufficiently similar in nature to the [1993 truck] bombing to raise a triable issue as to foreseeability." The Appellate Division affirmed on the opinion below and the cases headed to a jury. ${ }^{87}$

The Port Authority's claim that such an attack was so remote as to be unforeseeable was rejected because it was burdened by the spurned

84. See 49 U.S.C. §A. 40101 (2006)

85. World Trade Ctr. Bombing Litig. Steering Comm. v. Port Auth., 2004 N.Y. App. Div. LEXIS 14720 (N.Y. App. Div. 2004).

86. The legislatures of New York and New Jersey enacted statutes with identical provisions pursuant to which the Port Authority waived its sovereign immunity to tort claims. See N.J.S.A. §§ 32:1-162; N.Y. McKinney's Unconsolidated Laws § 71061, et seq. (McKinney 2007) (providing "Although the Port Authority is engaged in the performance of governmental functions, the said two States consent to liability on the part of the Port Authority in such suits, actions or proceedings for tortious acts committed by it and its agents to the same extent as though it were a private corporation.").

87. In re World Trade Center Bombing Litig., 776 N.Y.S. 2d 713, 735 (NY County Sup. Ct. 2004), aff'd in In re World Trade Ctr. Bombing Litig. Steering Comm. v. The Port Auth. of N.Y. \& N.J., 784 N.Y.S.2d 869 (N.Y. App. Div. 2004). 
study of the Port Authority's own Office of Special Projects (OSP) which traveled to London to study how the police there dealt with terrorism by the IRA and others. The OSP reported to Port Authority management what would become the refrain in the opening argument of the plaintiffs trial attorney, David Dean, a trial lawyer from central casting: the authorities at Scotland Yard told Port Authority officials in August 1984 that they were "appalled to hear we had transient parking directly underneath the towers." 88

At trial in October 2005 the plaintiffs prevailed. The New York County jury by a 6-0 vote found that the Port Authority "was negligent by not maintaining the World Trade Center's parking garage in a reasonably safe condition on February 26, 1993." Apportioning liability "between defendant Port Authority and the bombers" the jury 6-0 attributed $68 \%$ to the Port Authority and $32 \%$ to "The Bombers." But on the final question-whether the Port Authority acted with "reckless disregard"- the jury reported an "impasse," with two in favor of the finding and four opposed. The most remarkable finding is the attribution of only $32 \%$ of the fault to "The Bombers." 89 This vote demonstrates the normative appeal of the enabling tort. As David Dean said to the jury in his opening argument "it was a terrorist's dream. Scotland Yard was appalled. $" 90$

Thanks to the work of government agents, such as John O'Neill, the FBI operative, and Richard Clarke, the National Security Council adviser, the government intelligence system was "blinking red" in the summer of 2001. But there does not appear to be a "Bin Laden determined to attack U.S." memo, or an OSP Scotland Yard alarum smoking gun pointing at the airlines, at Boeing, or at the airport operators. ${ }^{91}$

Nonetheless when the $9 / 11$ tort cases against the aviation defendants reach trial there will be a mound of evidence, echoing the $9 / 11$ Commission Report, that passenger pre-screening, checkpoint screening, and onboard security were "seriously flawed." And there will be grim accounts showing that despite the "warning" of 1993, the World Trade Center evacuation plans, protocols, training, and instruction were grossly inadequate, and that the narrow stairways, radio failures, and

88. Id. at 719 .

89. In the Matter of World Trade Center Bombing Litigation, Index No. 600000/94 (jury interrogatory sheet on file with author).

90. Interview with David Dean, Esq., Senior Trial Attorney, Sullivan Papain Block McGrath \& Cannavo, P.C., in New York City (January 2006).

91. The National COMmission on TerRoRist ATtacks Upon the United States, THE 9/11 COMMISSION REPORT 259 (2005). 
communication problems at the towers cost many lives. ${ }^{92}$

When trial is reached much of the political pressure discussed above will not be present. All qualifying 9/11 victims-except the few plaintiffs-have accepted the compensation offered by the September 11 Victims Compensation Fund. ${ }^{93}$ The ATSSSA's limitation of liability to insurance in place on $9 / 11$ relieves the court (and jury if they learn of it-this being the age of Google, after all) of the prospect of helping to drive airlines and aircraft manufacturers into financial ruin. In such a circumstance it will be easier to focus on the fault of the airlines, of the security personnel, and of Boeing. Because of the aggregate damages limits and the compensation of Fund claimants, pressure to reject the imposition of tort liability by the retributive principle will be less compelling. No great disproportion between wrong and harm will be posed by the imposition of liability on the insured defendant manufacturers, airlines, airports, and landlord.

We are accustomed to thinking of retribution as a limiting principle in criminal law-let the punishment fit the crime. ${ }^{94}$ But the principle also has vitality in the civil liability setting for non-intentional torts. This issue is given to the jury for comprehension within the proximate cause determination, that there must be a "reasonably close causal connection between the conduct and the resulting injury" between the breach and the harm, as Prosser put it in his famous summary of the elements of the tort of negligence. ${ }^{95}$ Similarly in New York, a jury is told that the wrong

92. See id. at 83 .

93. John G. Culhane, Torts, Compensation, and Two Kinds of Justice, 55 RUTGERS L. REV. 1027 (2005) (The plan itself is better described as social insurance scheme, rather than a tort-replacement plan. Because the government, not the actors, was the payor but not the wrongdoers' insurer the provision of roughly full compensation for economic losses is not a corrective justice measure [restoring the status quo ante]. The scheme, which replicated the existing inequitable distribution of wealth, is unjustified on distributive justice grounds. A scheme which provided equal benefits to each victim or the survivors would have met distributive justice concerns.).

94. The limitation reaches back to the Magna Carta, as the California Supreme Court's recent discussion of punitive damages reminded us. The Charter Magna Carta limited civil sanction, providing that a wrongdoer may be "amerced... saving his wainnage" - that is, saving the means which permit him to carry on husbandry, including his "wain"- - his wagon and other tools and means. See Adams v. Murakami, 813 P.2d 1348, 1352-53 (Cal. App. 1991) ("A freeman shall only be amerced for a small offence according to the measure of that offence. And for a great offence he shall be amerced according to the magnitude of the offence, saving his contentment; and a merchant, in the same way, saving his merchandize. And a villain, in the same way, if he fall under our mercy, shall be amerced saving his wainnage." (quoting Magna Carta (1215))). Consideration of the defendant's financial condition is relevant to ensure that the amount of punitive damages is sufficient to punish and deter, but not so great as to cause financial ruin. See, e.g. Herman v. Sunshine Chem. Specialties, Inc., 627 A.2d 1081, 1087 (N.J. 1993).

95. William L. Prosser, Prosser on Torts, $§ 35$ (2d ed. 1955). 
must be a "substantial factor," one that reasonable persons would regard as a cause and not a "slight or trivial" factor. ${ }^{96}$

The requirement of a reasonable relationship between fault and the burden of making good the harm inflicted is also expressed in the concept of intervening cause. In New York the jury is instructed, "If you find that a reasonably prudent person would not have foreseen an act of the kind committed by (the attackers) as a probable consequence of the defendant's negligence, then the defendant is not responsible for the plaintiff's injuries and plaintiff may not recover."97 The 9/11 plaintiffs have the 1993 truck bombing to point to as indicator of risk of terrorist attack on the WTC in particular. The defense of intervening cause seems unlikely to be the basis for a ruling as a matter of law because the "slender and temporal reed" of which Judge Hoeveler spoke concerns the foreseeability of attack which negates the "intervening cause" defense. The jury verdict in the 1993 WTC bombing case shows that the obstacle can be overcome by plaintiffs.

Where, as here, there is insurance available to cover the cost and to limit the weight of the burden shifted, New York courts (and therefore the Southern District applying New York law) may be less inclined to use the concept of duty to avoid liability for the claims of those on the ground on 9/11 and would likely allow the tort claims to proceed. The legislated aggregate cap on damages at insurance coverage limits is a sum-certain surrogate for the limits imposed by the retributive principle of justice. Although the availability of insurance is considered potentially prejudicial to the defendants, and its existence is routinely not disclosed to the jury, the availability of insurance coverage is a routine consideration for the court in determining duty, e.g. whether to impose strict liability, particularly in "strict" product liability cases. ${ }^{98}$

The 9/11 ground victims and passengers tort actions, brought by those who have foregone the opportunity for no-fault compensation presents the opportunity for the civic judgments to be made that underlie the appeal and importance of the law of torts: first, assessment of whether the actors (both the aviation defendants and the managers of the WTC) took sufficient account of the interests of others-those in the planes and those on the ground-in their conduct; and second, requiring

96. N.Y. Pattern Jury Instr., Civil 2:70.

97. N.Y. Pattern Jury Instr., Civil 2:72.

98. For example, note "insurance availability," the 7th and final item in the list of risk-utility factors cataloged by Dean John Wade to guide courts determinations of whether to impose "strict liability in tort" in product liability cases. John W. Wade, On the Nature of Strict Tort Liability for Products, 44 Miss. L.J. 825, 837-38 (1973) (Although the "risk utility" factors are commonly the core of jury instructions on product defect, their original formulation by Wade was commended to courts as factors for consideration on whether to impose strict liability in tort on product sellers.). 
them to bear the costs that their wrongful conduct imposed on others (within legislated limits which function as limits imposed by the retributive principle).

As a sympathizer with the impulse to compensate fully and quickly the victims and the families of the victims of September 11, 2001, I will not engage in the substantial debate about whether it can or should be replicated (though both seem doubtful). The Fund's awards for pain and suffering, and the legislative commitment to approximately full repair of economic loss (collateral sources excepted) created ambiguity about whether it was providing social insurance or liability insurance. The Fund and the Special Master, by some alchemy of transference, came to stand for the tortfeasors. The struggles with claimants which the Special Master has described in his Final Report suggest that the proposed awards were viewed by many of the aggrieved not as the nation's extraordinary response to tragedy, but rather as the kind of metaphor of judgment of wrongdoing and repair of loss that tort verdicts symbolize.

It may be nonetheless that despite, or because of, its doctrinal impurity, the ATSSSA's combination of no-fault social insurance compensation with an optional and limited tort remedy will prove itself to have been a very judicious choice-one which will bring closure, compensation and social, moral tort judgment under tragic circumstances.

III. Epidemic and Mass Tort Litigation at Ground Zero

\section{A. Dust and Disease}

In the days following the attacks, officials were eager to reassure the public and to hasten a return to normalcy. An early concern was the hazard presented by the smoldering ruins of the World Trade Center. Environmental testing began quickly but no one had ever tested a toxic mix such as the pulverized towers presented. Hasty assurances were offered-most notoriously by the Environmental Protection Agency (EPA) Administrator Christine Todd Whitman. The former Governor of New Jersey made statements so broadly reassuring that United States District Judge Deborah Batts concluded that Whitman did not establish the defense of qualified immunity because

(n)o reasonable person would have thought that telling thousands of people that it was safe to return to Lower Manhattan, while knowing that such return could pose long-term health risks and other dire 
consequences, was conduct sanctioned by our laws. ${ }^{99}$

There was much to regret. A report by the Office of the Inspector General of the EPA (OIG) ${ }^{100}$ concludes that

EPA's early public statements following the collapse of the WTC towers reassured the public regarding the safety of the air outside the Ground Zero area. However, when EPA made a September 18 announcement that the air was "safe" to breathe, it did not have sufficient data and analyses to make such a blanket statement. ${ }^{101}$

The OIG recounts that EPA failed to "assert its opinion and judgment on matters that impact human health and the environment."102 White House Council on Economic Quality vetting of EPA press releases had led to ill-considered down-playing of health risks by the EPA. For example one draft EPA press release said

Recent samples of dust gathered by OSHA ... show higher levels of asbestos. Seven debris and dust samples taken Thursday (September 13) showed levels of asbestos ranging from 2.1 percent to 3.3 percent. EPA views a 1 percent level of asbestos as the definition for asbestos-containing material. ${ }^{103}$

But after White House vetting, the statement became:

The new samples confirm previous reports that ambient air quality meets OSHA standards and consequently is not a cause for public concern. New OSHA data also indicates that indoor air quality in downtown buildings will meet standards... EPA continue(s) to believe that there is no significant health risk to the general public.... Debris samples... outside buildings on cars and other surfaces contained small percentages of asbestors (sic), ranging from 2.1 to 3.3 -slightly above the 1 percent trigger for defining asbestos material. ${ }^{104}$

Under the principal direction of New York City's Department of Design and Construction and its subcontractors, ${ }^{105}$ thousands of workers

99. Benzman v. Whitman, 2006 U.S. Dist. LEXIS 40 (S.D.N.Y. 2006).

100. EnVironmental Protection Agency, OfFice of the Inspector General, Evaluation Report: EPA's Response to the World Trade Center Collapse: Challenges, Successes, and AREas for Improvement, Report No. 2003-P-00012, August 21, 2003 [hereinafter OIG Report].

101. Id. at i.

102. Id. at 7 .

103. OIG Report at 16.

104. Press Release, Report of the Office of the Inspector General of the EPA Instruction on September 16 (Sept., 16, 2001), cited in OIG Report.

105. In re World Trade Center Disaster Site Litigation, S.D.N.Y., 21 MC 100 (AKH), Plaintiffs' statement of undisputed material facts, at paragraphs 1-4, April 7, 2006. 
labored for months in deadly dust without adequate respiratory protection. Equipment was available-OSHA reported giving out 130,000 half-face, cartridge respirators, the EPA gave out 22,000 and the International Union of Operating Engineers provided 11,000. ${ }^{106}$ But delay and enforcement shortcomings were substantial. ${ }^{107}$ There was little effort to properly fit the masks, to educate workers regarding the risks, to overcome the considerable misinformation that had been put forth, or to enforce the equipment's use by the workers on what came to be called "the pile," the long smoldering ruins of the towers. ${ }^{108}$

Even among the heavy equipment operators, a disciplined, skilled, and highly paid cadre with a strong union, only $50 \%$ were observed to be using respirators in the October 2-16, 2001 observation period. Fit tests were not offered widely on-site until 36 days after the disaster, a formal safety and health plan was not issued until 48 days after the event, and the first formal onsite safety training occurred 77 days after the collapse. ${ }^{109}$

The conditions for immigrant day laborers were predictably grim. They had been given little protective equipment. Even less safety and health information was given to day laborers than the highly unionized workers on "the pile" received. Few had health insurance. The World Trade Center Day Labor Monitoring Project examined 418 building clean-up workers from January 15 through February 28, 2002. Nearly all workers reported health problems that began while working near the WTC site. ${ }^{110}$

106. BRUCE E. LIPPY, Safety and Health of Heavy Equipment Operators at Ground Zero, 42 AmERICAN Journal of Industrial MEDiCINE 539, 540 (2002). Lippy, an industrial hygienist, is Director of Research and Special Projects at the National Hazmat Program of the International Union of Operating Engineers.

107. Plaintiffs' statement of undisputed material facts, at paragraphs 81-84 (Though the City and contractors had 25,000 Tyvek protective suits they were not provided to workers at Ground Zero, in marked contrast to the Fresh Kills landfill were availability and compliance levels were high. Most workers did not receive respirator fit testing at the WTC site, and that which was done did not meet OSHA standards.).

108. Plaintiffs' statement, paragraphs 68-79 (City's environmental health and safety plan was neither enforced nor properly disseminated to workers at the WTC site); Paul A. Lioy and Michael Gochfeld, Lessons Learned on Environmental, Occupational, and Residential Exposures from the World Trade Center Attacks, 42 AM. J. OF INDUSTRIAL MEDICINE 560 (2002) (In a natural or security emergency, response situation workers must be protected against one or more substances. Merely making respirators available does not assure their use. However, to implement such a program research needs to be conducted on the design of a respirator to ensure that emergency responders use respiratory protection, and use it in the correct manner. Many of the non-air pack respirators are heavy and not easily worn over the nose and mouth during complex task operations.).

109. Lippy, supra note 106, at figure 2.

110. Ekaterina Malievskaya, et al., Assessing the Health of Immigrant Workers Near Ground Zero: Preliminary Results of the World Trade Center Day Laborer Medical 
By October 2002 significant health consequences for the Ground Zero workers were reported. The American Journal of Industrial Medicine devoted an issue to the health problems of the thousands of Ground Zero workers. The journal reported that "the result will almost certainly be unnecessary disease and death." 111 Public health surveillance is a series of snapshots. The moving picture appears only after many shots have been taken, edited, arranged, and shown in sequence. In April 2002, a medical surveillance program was established at the Irving J. Selikoff Center for Occupational and Environmental Medicine, Mount Sinai Medical Center, New York City. ${ }^{112}$ In September 2006 the Mt. Sinai program issued a five year assessment. The results were dramatic. Sixty-nine percent of 9,442 responders examined between July 2002 and April 2004 reported new or worsened respiratory symptoms that occurred while performing WTC work, and symptoms persisted to the time of examination in $59 \% .{ }^{113}$

At five years, the legacy of World Trade Center Dust is complex, uncertain, and contentious. Granulomatous pulmonary disease and airway hyperreactivity are reported among New York City Fire Department rescue workers. The City's chief medical examiner has for the first time linked a death to the dust. Dr. Charles S. Hirsch wrote that "accumulating evidence" links "WTC dust" to "sarcoidosis or an inflammatory reaction indistinguishable from sarcoidosis." Felicia Dunn-Jones, a 42 year old lawyer, was engulfed as she ran from her

Monitoring Project, 42 AM. J. OF INDUSTRIAL MED. 548-49 (2002).

111. See Landrigan, supra note 11.

112. See National Institute for Occupational Safety and Health, World Trade Center Response, http://www.cdc.gov/niosh/topics/wtc/.

113. Robin Herbert, et al., The World Trade Center Disaster and the Health of Workers: Five-Year Assessment of a Unique Medical Screening Program, 114 ENVTL. HEALTH PERSPECT. 1853, 1853-58 (2006), available at http://dx.doi.org/ (Approximately 40,000 rescue and recovery workers were exposed to caustic dust and toxic pollutants following the September 11, 2001 attacks on the World Trade Center (WTC). These workers included traditional first responders such as firefighters and police and a diverse population of construction, utility, and public sector workers.) Id at 1854. The WTC Worker and Volunteer Medical Screening Program was established to characterize WTCrelated health effects. This multi-center clinical program provides free standardized examinations to responders. Examinations include medical, mental health, and exposure assessment questionnaires, physical examination, spirometry, and chest $\mathrm{x}$-ray. Sixty-nine percent of 9,442 responders examined between July 2002 and April 2004 reported new or worsened respiratory symptoms while performing WTC work. Symptoms persisted to the time of examination in $59 \%$. Among those who had been asymptomatic before $9 / 11$, $61 \%$ developed respiratory symptoms while performing WTC work. Twenty-eight percent had abnormal spirometry. FVC was low in $21 \%$ of our population. Obstruction was present in $5 \%$. Among non-smokers, $27 \%$ had abnormal spirometry vs. $13 \%$ in the general U.S. population. Prevalence of low FVC among nonsmokers was five-fold greater than in the U.S. population ( $20 \%$ vs. $4 \%$ ). Respiratory symptoms and spirometry abnormalities were significantly associated with early arrival at the site.). 
office a block from the trade center. She died on February 10, 2002, diagnosed with sarcoidosis. Hirsch concluded "whether or not she had sarcoidosis prior to $9 / 11 / 01$ it is likely, with certainty beyond a reasonable doubt, that exposure to W.T.C. dust was harmful to her." $\mathrm{He}$ ruled the dust "was contributory to her death." 114

Samet, Geyh and Utell report that some conclusions can be drawn. First, the toxic mix and exposure levels are uncertain. Some responders present in the days and hours after the disaster "have persistent respiratory abnormalities consistent with inhaled particles and gases." Any associated risk of respiratory and other cancers "will not be known for decades." The respiratory health of the general population "may have been affected." Determination of "actual causal contribution of the dust to future risk of disease" will require "decades of commitment" to public health surveillance and monitoring, especially of responders. But "even the full suite of research efforts in progress may never provide the evidence needed" to answer all the questions that will be raised about the long term health effects of the events of September 11. ${ }^{115}$

\section{B. The Ground Zero Workers Respiratory Injury Tort Claims}

Over three thousand Ground Zero workers have now filed claims for respiratory illness, alleging exposure to and inhalation of "noxious fumes, toxic substances, particulates and caustic substances." " Their pleas have prompted governmental responses. The City of New York established the World Trade Center Health Registry to follow the workers and trace their health. ${ }^{117}$ The New York Legislature has made adjustments in the workers compensation statute of limitations for any injuries that manifest themselves after the normal two year statute has expired. ${ }^{118}$ There have been adjustments in the New York State pension

114. Anthony DePalma, For the First Time, the City Connects a New York links a Death to 9/11 Dust, N.Y. TIMES, May 24, 2007, at B1.

115. Jonathan M. Samet, Alison S. Geyh, \& Mark Utell, The Legacy of World Trade Center Dust, 356 NEw ENG. J. MED. 2233, 2233-36 (2007).

116. World Trade Center Disaster Site Respiratory cases, U.S. District Court, S.D.N.Y., consolidated on the docket as $21 \mathrm{MC} 100$; checkoff complaint, etc.

117. The City of New York's WTC Health Registry describes itself as "a comprehensive and confidential health survey of those most directly exposed to the events of 9/11/01. It will give health professionals a clear picture of the health consequences of $9 / 11 / 01$. Those who enrolled answered a 30-minute telephone survey about where they were on $9 / 11 / 01$ and when reported, were asked to report the status of their health. This will allow health professionals to compare the health of those most exposed to the events of $9 / 11 / 01$ with the health of the general population." See http://www.nyc.gov/html/doh/html/wtc/index.html.

118. N.Y. WORKERS' COMPENSATION LAW $\S 163$ (McKinney 2006) S.8348, passed August 14, 2006 (Creating a new Article 8-A of the workers compensation law: "World Trade Center Rescue, Recovery, and Clean-Up Operations ... \& 163 Notice shall be 
laws to allow recognition of WTC respiratory illnesses. ${ }^{119}$

Workers find themselves fighting for workers compensation benefits, ${ }^{120}$ as well as pressing the traditional tort litigation now pending in the federal court before Judge Hellerstein. For those who have represented industrial workers in asbestos and other occupational disease claims it is deja vu. But there are differences, principally the exclusive federal jurisdiction, coverage limits, and the defense that the State Disaster Emergency Act (SDEA) confers immunity on the City of New York as the master general contractor in control of the site and that the immunity extends to its construction managers and subcontractors. ${ }^{121}$ Those claims are covered by the WTC Captive Insurance Company's $\$ 1$ billion excess liability policy. ${ }^{122}$

The exclusive federal cause of action has been found to extend to the thousands of workers who have alleged injury during their work at

given to the employer, or in the case of a volunteer, to the [Workers Compensation] Board, within two years after the disablement of the participant or after the participant knew or should have known that the qualifying condition was causally related to his or her participation in world trade center rescue, recovery and clean-up operations, whichever is the later date.").

119. N.Y. RETIRE. \& SOC. SEC. LAW $\S 63$ (Consol. 2007) (establishing conditions for accidental disability for state employees - setting a presumptive causal link between WTC work in excess of 40 hours and "qualifying impairments," such as upper respiratory, gastrointestinal tract, contact burns and dermatitis, and psychological impairments).

120. Sewell Chan, City Workers' 9/11 Claims Meet Obstacles, N.Y. TIMES, May 22, 2006 , at Bl ("Workers going through this process are being fought tooth and nail, while justice and humanity call for providing them with the medical treatment that they need," said Joel A. Shufro, executive director of the New York Committee for Occupational Safety and Health, a union-backed nonprofit educational organization that has often criticized the city's handling of compensation claims. Dr. Robin Herbert, an occupational-medicine specialist and incoming director of the World Trade Center Health Effects Treatment Program at Mount Sinai Medical Center, said the workers' compensation program was one of the most common sources of complaint among her patients. "There's no question that our patients who have physical and mental health consequences of the World Trade Center disaster have had their psychological distress worsened by the difficult interactions with the workers' compensation system," she said.). See also, Press Release, Office of the Governor, New York State (Aug. 14, 2006) ("The Governor ... announced a comprehensive plan to ensure that $9 / 11$ rescue workers receive prompt access to the benefits and health care they rightfully deserve under the State's workers compensation system. The plan creates additional flexibility to provide coverage for health care while claims are being litigated by the insurer, ensures access to medical procedures that require pre-approval in a more time-sensitive manner, and calls upon insurers to exercise options available to them under current law to provide workers compensation benefits to claimants before their cases have been fully resolved.").

121. See, e.g. Defendants Reply Memorandum on federal immunity, May 12, 2006, and Defendants's Reply Brief on State Statutory and Common Law Immunity, May 12, 2006 .

122. See Policy of World Trade Center Captive Insurance Company, Inc., $\S 2$ Coverage, $\S 4$, Limits of Liability. 
the site of the destroyed towers. ${ }^{123}$ ATSSSA $\S 408$ limited the liability of the City of New York "the greater of the city's insurance coverage or $\$ 350,000,000$ " for all claims "arising from the terrorist related aircraft crashes of September 11, 2001. ${ }^{124}$ Congress funded the WTC Captive Insurance Company, Inc., which provides $\$ 1,000,000,000$ aggregate limit excess liability insurance to the City and its contractors for personal injury claims arising post collapse from "debris removal" from the World Trade Center site. ${ }^{125}$

The Ground Zero respiratory claims have been consolidated for discovery and are managed by Judge Hellerstein. ${ }^{126}$ The cases present a familiar array of "mass tort" problems such as have been seen in asbestos litigation. ${ }^{127}$ The claims are numerous, feature hard-fought, all-out, well-

123. See generally McNally v. Port Auth. of N.Y. \& N.J., 414 F.3d 352 (2d Cir. 2005).

124. ATSSSA $\S 408(a)(3)$.

125. See Captive policy, supra note 122.

126. $21 \mathrm{MC} 100(\mathrm{AKH})$, Southern District of New York.

127. See, e.g., H.R. 1360, The Fair Asbestos Injury Resolution Act of 2005, H.R. 1360,109 th Cong. $\S$ Section 2 (2005):

(a) Findings - Congress finds the following:

(1) A great number of Americans have been exposed to forms of asbestos that can have devastating health effects.

(2) Various injuries can be caused by exposure to some forms of asbestos, including pleural disease and some forms of cancer.

(3) The injuries caused by asbestos can have latency periods of up to 40 years, and even limited exposure to some forms of asbestos may result in injury in some cases.

(4) Asbestos litigation has had a significant detrimental effect on the country's economy, driving companies into bankruptcy, diverting resources from those who are truly sick, and endangering jobs and pensions.

(5) The scope of the asbestos litigation crisis cuts across every State and virtually every industry.

(6) The United States Supreme Court has recognized that Congress must act to create a more rational asbestos claims system. In 1991, a Judicial Conference Ad Hoc Committee on Asbestos Litigation, appointed by Chief Justice William Rehnquist, found that the 'ultimate solution should be legislation recognizing the national proportions of the problem ... and creating a national asbestos dispute resolution scheme... . The Court found in 1997 in Amchem Products Inc. v. Windsor, 521 U.S. 591, 595 (1997), that ' $[\mathrm{t}]$ he argument is sensibly made that a nationwide administrative claims processing regime would provide the most secure, fair, and efficient means of compensating victims of asbestos exposure.' In 1999, the Court in Ortiz v. Fibreboard Corp., 527 U.S. 819, 821 (1999), found that the "elephantine mass of asbestos cases ... defies customary judicial administration and calls for national legislation.' That finding was again recognized in 2003 by the Court in Norfolk \& Western Railway Co. v. Ayers, 123 S.Ct. 1210 (2003).

(7) This crisis, and its significant effect on the health and welfare of the people of the United States, on interstate and foreign commerce, and on the bankruptcy system, compels Congress to exercise its power to regulate 
funded defense, threats of bankruptcy, unique non-replicable toxic exposures, delayed manifestation of disease, evolving scientific data, uncertainties regarding causal relationship, pressing needs for medical treatment, contested workers compensation claims, contributory negligence defenses, prospects of having to divide a limited fund when not all claims are yet known and not all diseases have yet manifested themselves, and, of course, expense for plaintiffs attorneys and delay for the plaintiffs. ${ }^{128}$ In such cases, calls for caps on recovery, limitation of claims, Special Masters and special Alternative Dispute Resolution methods are common.

\section{Familiar Ground: New York Labor Law \$ 241-Strict Liability for Workers Doing Construction and Demolition Work}

Tort law retains its vitality in the Ground Zero respiratory cases because Congress, in the ATSSSA, treated the exclusive federal remedy like a diversity action, incorporating the substantive law of New York except to the extent it is preempted by federal law. So the action proceeds in a familiar way, like a diversity case removed to federal court in which the federal court is the forum but the substantive law is typically that of the state where the cause of action arose. ${ }^{129}$

Article 10 of New York's Labor Law establishes a statutory cause of action for construction, repair, and demolition work. Its most protective provision, $\S 241(6)$ has often been described as establishing strict liability. $\S 241$, entitled "Construction, excavation and demolition work," provides:

interstate commerce and create this legislative solution in the form of a national asbestos injury claims resolution program to supersede all existing methods to compensate those injured by asbestos, except as specified in this Act.

(b) Purpose-The purpose of this Act is to-

(1) create a privately funded, publicly administered fund to provide the necessary resources for a fair and efficient system to resolve asbestos injury claims that will provide compensation for legitimate present and future claimants of asbestos exposure as provided in this Act;

(2) provide compensation to those present and future victims based on the severity of their injuries, while establishing a system flexible enough to accommodate individuals whose conditions worsens;

(3) relieve the Federal and State courts of the burden of the asbestos litigation and;

(4) increase economic stability by resolving the asbestos litigation crisis that has bankrupted companies with asbestos liability, diverted resources from the truly sick, and endangered jobs and pensions.

128. See JeAn Macchiaroli EgGen, Toxic Torts at Ground Zero, 39 ARIz. ST. L.J. 383 (2007) (providing a comprehensive survey of the range of legal and factual issues presented by claims of workers and residents of lower Manhattan).

129. 28 U.S.C. $\S 1332(2002)$. 
All contractors and owners and their agents, except owners of one and two-family dwellings who contract for but do not direct or control the work, when constructing or demolishing buildings or doing any excavating in connection therewith, shall comply with the following requirements:

6. All areas in which construction, excavation or demolition work is being performed shall be so constructed, shored, equipped, guarded, arranged, operated and conducted as to provide reasonable and adequate protection and safety to the persons employed therein or lawfully frequenting such places. The commissioner may make rules to carry into effect the provisions of this subdivision, and the owners and contractors and their agents for such work ... shall comply therewith. ${ }^{130}$

The statute has long been understood to impose liability on owners for injuries arising from unsafe conditions even if they did not know of the hazard, ${ }^{131}$ and even if they exercised no control over the work. ${ }^{132}$ In Rizzuto v. Wenger Contracting Co. ${ }^{133}$ the Court of Appeals held that the plaintiff need not show the existence of a specific provision of the industrial safety code in order to make out a cause of action under $\S 241$ of New York's Labor Law.

Plaintiffs' lawyers in the Ground Zero cases are on familiar ground. Tort retains its familiar rhythms, boundaries, and purpose. Without it the workers would be limited to the $\$ 400 /$ week maximum benefit provided by New York workers compensation law. ${ }^{134}$ But they also must work to

130. N.Y. CLS LABOR LAW $§ 241$ (Consol. 2007).

131. See generally Allen v. Cloutier Constr. Corp, 376 N.E.2d 1276 (N.Y. 1978) (A married couple contracted for the construction of a one family dwelling on land owned by them. An employee of a plumbing subcontractor was killed in a trench cave-in during construction of the house. The couple was held to be subject to strict liability under subdivision 6 of section 241 because of non-compliance with safety rules promulgated by the Board of Standards and Appeals. The couple's argument that they had no direction or control over the work was held without effect in light of the statute's clear imposition of strict liability on owners). The statute was later amended to exclude two family home owners who did not retain control.

132. See generally Haimes v. N.Y. Tel. Comp., 385 N.E.2d 601 (N.Y. 1978) (Defendant argued against strict liability where a self-employed independent painting contractor fell to his death while painting a cornice on a building owned by defendant who exercised no direction or control over the decedent's work. The Court expanded and reinforced the rationale in Allen that owners, regardless of their status, and regardless of their lack of direction and control, are strictly liable, in this case under section 240.).

133. See generally Rizzuto v. Wenger Contracting Co., 693 N.E.2d 1068 (N.Y. 1998).

134. On March 13, 2007 the Governor of New York signed Chapter 6 of the Laws of 2007 [A.6163/S.3322] raising the maximum weekly rate for total disability to $\$ 500 /$ week from $\$ 400 /$ week for accidents occurring after July 1, 2007. Death benefits are capped at $\$ 750 /$ week, an increase from \$600/week. See Workers' Compensation Board, Change in Workers' Compensation Benefit Rates, (2007), http://www.wcb.state.ny.us/content/main/ 
establish that their conditions are causally related to their WTC work in order to get workers compensation benefits. In the tort actions they will find the familiar hurdles of cause in fact, proximate cause and contributory negligence waiting, though where it can be shown that the employer, contractor, or owner did not provide any safety devices, the defense of comparative negligence is unavailable. ${ }^{135}$ And there are those most familiar burdens of the well-defended case, delay and expense.

\section{Civil Defense and Emergency Immunity}

The Ground Zero workers filed their complaints in New York State Supreme Court. The City, its contractors, and the Port Authority of New York and New Jersey removed the state tort actions to federal court, citing ATSSSA $\S$ 408(b). However, Judge Hellerstein remanded the actions to the state trial court as not arising from September 11, except to the extent that they asserted injuries incurred before the emergency ended on September 29, 2001 with the official declaration that the search for survivors had ended. ${ }^{136}$ The defendants appealed from the remand order. It was reversed, with the suggestion by Judge Kearse for the Second Circuit in McNally v. Port Authority ${ }^{137}$ that the September 29 cutoff date for exclusive federal jurisdiction was unpersuasive. The actions remained venued in the Southern District of New York before Judge Hellerstein.

The City, its contractors, and the Port Authority moved to dismiss the complaints based on immunity grounds. The defendants say they are immune under the federal Stafford Act, which, tracking the Federal Tort Claims Act, ${ }^{138}$ provides immunity for discretionary acts. ${ }^{139}$ They also rely on a civil defense measure, New York's State Defense Emergency Act (SDEA).

SubjectNos/sn046_183.htm (last accessed Aug. 8, 2007).

135. See generally Zimmer v. Chemung County Performing Arts, 482 N.E.2d 898 (N.Y. 1985).

136. See Hickey v. City of New York (In re World Trade Ctr. Disaster Site Litig.), 270 F. Supp. 2d 357, 380 (S.D.N.Y., 2003) (The last survivor was found on September 12.).

137. McNally v. Port Auth., 414 F.3d 352 (2d Cir. 2005).

138. 28 U.S.C. $\$ 2674$ (2002).

139. 42 U.S.C. $\$ 5121$, et seq (2002). The liability provision in $\$ 5148$ recites the familiar discretionary/ministerial function defense. See Federal Tort Claims Act 28 U.S.C. 2674-2680:

The Federal Government shall not be liable for any claim based upon the exercise or performance of or the failure to exercise or perform a discretionary function or duty on the part of a Federal agency or an employee of the Federal Government in carrying out the provisions of this Act. 


\section{Stafford Act Immunity}

The City, its contractors, and construction managers argued that "[o]ur nation's devastating experiences with the September $11^{\text {th }}$ attacks and the more recent hurricane Katrina recovery have poignantly illustrated the need for federal agencies to be able seamlessly and productively co-ordinate their efforts with their state and local counterparts as well as with responding private contractors."140 The defendants assert that the Stafford Act, $\S 5148$, provides such protection. The City and its contractors, who began work first under the supervision of the City's Emergency Management Office ${ }^{141}$ and the Department of Design and Construction, which hired all the contractors and had control of the site, were said to be entitled to "derivative (Stafford Act) federal immunity for any claims brought by plaintiffs alleging that the negligent, faulty, fraudulent, or non-performance of those activities" in which a "federal agency had explicitly assumed the lead role."142

But the defense rhetoric, which has superficial appeal, must confront the plain language of $\S 5148$, which limits immunity to discretionary functions. Under New York Labor Law $\S 240$, it is not a discretionary function but rather is actionable to fail to provide workers with adequate safety equipment, accurate information for preservation of their health, and to violate safety codes such as those adopted by the U.S. Department of Labor in OSHA and the State of New York. Failure to implement safety codes is not a discretionary judgment, but rather an operational decision. $^{143}$ The basic principles of the Federal Tort Claims

140. Defendants' Memorandum in Support of Motion for Summary Judgment Based on Federal Immunity.

141. Its command center in WTC 7 was destroyed when the tower collapsed. The building, the Con-Ed substation underneath and the huge store of diesel fuel were major sources of contaminants. Property damage claims of design defect were rejected. Aegis Ins. Servs. v. Port Auth., 2006 U.S. Dist. LEXIS 749 (S.D.N.Y. 2006).

142. Defendants' Memorandum in Support of motion for summary judgment based on federal immunity, at p. 2.

143. Daly v. Port Auth. of N.Y. \& N.J., at 721 (stating:

(P)laintiffs base their claims on defendants' alleged failure to perform nondiscretionary duties, i.e., the mandatory, nondelegable requirements of Labor Law $\S 240(1)$ and $\S 241(6)$ and the Industrial Code. (Compare DiFlorio $v$ Worden, 303 A.D.2d 924, 755 N.Y.S.2d 679 [4th Dept 2003] [no evidence of fixed, clearly defined duty].). If, in the circumstances presented, Labor Law $\S 240(1)$ and $\S 241(6)$ were applicable, . . . the City would have been no more free to violate them than it would have been free to violate the Prevailing Wage Law (Labor Law $\$ 220$ ), had it been applicable. Neither the City nor any other entity has discretion to violate an applicable statute. Executive Law $\S 25(5)$ HN24 does not automatically exempt a political subdivision from liability for every act that its employees or agents perform in the course of a large project, solely because the subdivision has discretion over how it organizes and executes that project. Rather, section $25(5)$ provides that a political subdivision 
Act are replicated by the Stafford Act. Judge Hellerstein gave little credence to the federal immunity argument during the two days of argument on the immunity motions June 22 and 26, 2006. ${ }^{144}$

\section{Defenses: Good Faith, Emergency and the SDEA}

Until memory was revived by the City and its contractors in their motions to dismiss, the Defense Emergency Act had been a dormant vestige of the Cold War years when we prepared for nuclear war with the USSR. But the SDEA remained on the books and it contains an immunity provision capable of broad construction:

the state, any political subdivision, municipal or volunteer agency, $* * *$ or any agency, member, agent or representative of any of them, or any individual, partnership, corporation, association, trustee, receiver or any of the agents thereof, in good faith carrying out, complying with or attempting to comply with any law, any rule, regulation or order duly promulgated or issued pursuant to this act, any federal law, $* * *$ or any order issued by federal or state military authorities, relating to civil defense, including but not limited to activities pursuant thereto, in preparation for anticipated attack, during attack, or following attack $* * *$ shall not be liable for any injury or death to persons or damage to property as the result thereof. $^{145}$

The immunity motions based on the State Defense Emergency Act are more formidable than those based on the Stafford Act. But the issue was ruled upon by the New York Supreme Court before the Second Circuit in McNally v. Port Authority ${ }^{146}$ directed in July 2005 that the respiratory cases proceed in federal court. In Daly v. Port Authority, New York Supreme Court Justice Michael Stallman rejected plaintiffs' argument that the Cold War civil defense act was obsolete and ineffective. He held that the police power of the state to protect the public health expressed in the maxim "salus populi suprema lex" immunized the State for negligent acts taken in the heat of emergency. Stallman ruled that the emergency ended on September 29, 2001 when the search for survivors was officially abandoned. ${ }^{147}$

The defense argued that preservation of the slurry wall, the search for human remains, and cleanup of Ground Zero until May 2002

\footnotetext{
"shall not be liable for any claim based upon ... the failure to exercise or perform a discretionary function or duty.).

144. See transcript of argument, passim. (on file with author).

145. N.Y. Unconsol. $\$ 9193$ (1) (emphasis added).

146. McNally v. Port Authority, 414 F.3d 352 (2d Cir. 2005).

147. Daly v. Port Auth., 793 N.Y.S. $2 d 712$ (N.Y. Sup. Ct., N.Y. County, 2005).
} 
constituted "civil defense" activities for which the defendant City and its contractors are immune. SDEA immunity, they argued, extends even to negligent acts, if the negligent parties acted with an honest purpose in good faith. Such an extension of the emergency period, Justice Stallman found, was unreasonable. ${ }^{148}$

Justice Stallman observed in Daly that the New York Court of Appeals had only once ruled on the scope of the SDEA's immunity provision. $^{149}$ In Abbott $v$. Page Airways, the high court had held that a helicopter operator, chartered by the state to fly over the scene of a prison rebellion, was not immune in a wrongful death action. The helicopter operator was engaging in its "normal business" and not in "civil defense activity under $\S 9193(1) . " 150$ In Abbott the high court evidenced a view that the statute should be narrowly construed to preserve the right to compensation. Stallman also noted that courts have consistently construed Labor Law $\S 240$ liberally in order to compensate construction and demolition workers for injuries on job sites with inherently hazardous work. ${ }^{151}$

Emergency does not relieve one of the duties of reasonable care. It is a circumstance to be considered by the jury or fact-finder in determining the reasonableness of conduct. ${ }^{152}$ Judge Hellerstein found this line of reasoning persuasive. Late in the two days of argument on the immunity motions he located in the statute the traditional use of the emergency concept in tort law. Judge Hellerstein observed:

Immunity from suit is a very important point because it means that something decided in haste should not be open to Monday morning post-event quarterbacking. The quarterback on the spot, the guy who makes the calls, the difficult calls, are to be given plenty of slack to be able to make those calls. And clearly, a government that acts for the welfare of all, and what's the Latin, Mr. Tyrrell ... Salus populi $^{153}$... to allow some of us to sue all of us for acts taken for the benefit of all is anomalous it's just wrong. . . . But when there is a call upon a certain class of people to work intensively for a long period of time, and to subject themselves to injuries which they claim were negligently caused, is a different situation, particularly when there's insurance monies to spread that out... When matters are

148. Id. at 721 .

149. Id. at 716 .

150. Abbott v. Page Airways, Inc., 23 N.Y.2d 502, 508 (N.Y. 1969).

151. Daly, 793 N.Y.S.2d at 716 (citing Wise v. 141 McDonald Avenue, 297 A.D. 2 d 515, 516 (N.Y. App. Div.1st Dept. 2002); Wilson v. City of New York, 89 F. 3d 32, 36 (2d Cir. 1996).

152. Daniel B. DoBbs, The Law of TORTS $\S \S 128-31$ (2000).

153. The Latin maxim is "salus populit suprema lex". The health of the people is the highest law. 
spread out over time, and insurance monies are gathered to help defray the expense, the burden of inequity may shift, and maybe protection is needed for the people who day after day risk their lives and their lungs in promoting the public weal. That's a difficult issue. $^{154}$

Judge Hellerstein has been loathe to make precipitous and early dispositive rulings. On October 16, 2006 he ruled as he had suggested he would. On the key issue in In re World Trade Ctr. Disaster Site Litigation, he held that the New York State Defense Emergency Act (SDEA) extends immunity, but not to all activities following an emergency. ${ }^{155}$ It limits immunity only to those activities that are, in themselves, "essential," or "immediately essential," and "emergency" in nature. ${ }^{156} \mathrm{He}$ thus construed the statute's text to limit immunity to activities that must be done immediately to resolve pressing needs, in order to enable society to prepare for an attack, and to begin to function following an attack. ${ }^{157}$ The respiratory claims will now proceed to discovery and trial.

Thousands of hours have already been spent in dozens of depositions and in obtaining and reviewing hundreds of thousands of documents to reconstruct the history of the ineffective safety and health command and control at the Ground Zero rescue, recovery, and debris removal operations. ${ }^{158}$ Many more days and weeks will be consumed as plaintiffs try to prove that the City and its contractors' claims of good faith conduct and emergency-dictated immunity claims are unwarranted and that the plaintiffs' diseases are reliably attributable to their exposures at the site of the World Trade Center.

154. Transcript of Proceedings before Alvin K. Hellerstein, D.J., In Re WTC Disaster Site Litigation, 21 MC 100, (S.D.N.Y.), June 26, 2006.

155. In re World Trade Ctr. Disaster Site Litig., 456 F. Supp. 2d 520, 553 (SDNY 2006).

156. Id. at $547-48$

157. Id. at 554 (footnote omitted) (stating:

The SDEA's immunity provision operates to ensure that fear of liability will not operate to dissuade government and private entities from responding to a disaster, even in the absence of otherwise mandated safety protocols and procedures. However, as the emergency condition fades, as the rights and obligations of persons and entities engaged in the response effort become regulated by contract, ... as procedures and protocols are implemented to protect against potential dangers, the need for immunity diminishes and the obligations and duties otherwise imposed once again must be protected.).

158. Transcript of Record at 140, In re World Trade Ctr. Disaster Site Litig., 21 MC 100 (S.D.N.Y. 2006). 


\title{
E. Aftermath of Judge Hellerstein's Decision to Allow the Ground Zero Cases to Proceed: Special Masters-and an Expanded 9/11 Victims Fund?
}

Judge Hellerstein's October 16, 2006 ruling, which denied the defense immunity motions without prejudice, demonstrated his intention to keep in his hands plenary power to move the parties to settle the cases. ${ }^{159}$ Hellerstein took further action quickly. On December 4, 2006 he retained jurisdiction of the non-respiratory claims. ${ }^{160} \mathrm{He}$ had in June 2006 ordered plaintiffs to "remove" all medical monitoring claims from their complaints. ${ }^{161}$ On December 12, 2006, using Federal Rule of Civil Procedure 53(a)(1)(C), he appointed as Special Masters two prominent academics, the Reporters for the American Law Institute's 1998 Products Liability Restatement. Hellerstein gave the professors a writ to work to structure the litigation with a view toward settlement:

\begin{abstract}
The Special Masters (James A. Henderson, Jr. and Aaron D. Twerski) will create intelligent and informative categories to enable cases to be considered efficiently and according to their particularized facts, ensuring that each case receives the individual treatment it deserves, while enabling the parties to value the claims and defenses, make appropriate motions, conduct relevant discovery, and organize trials. The purpose of the Special Masters' involvement is not to resolve disputed issues of fact or law, but to monitor compliance with court orders, and help organize the cases to facilitate their efficient and just progress. Without their help, neither plaintiffs nor defendants will be able to organize and present the facts and issues, delaying justice, and perhaps denying it entirely. ${ }^{162}$
\end{abstract}

The court's approach is well supported by accumulated judicial experience. An example is that of New Jersey. Most of the asbestos in orth America was processed there. Its refineries, shipyards, and smelting plants consumed enormous quantities of the mineral. A massive

159. World Trade Litig., 456 F. Supp. 2d 520 (S.D.N.Y. 2006).

160. In re World Trade Ctr. Disaster Site Litig., 467 F. Supp. 2d 367, 374 (SDNY 2006)

161. Judge Hellerstein noted in his order denying the partics objection to his appointment of Special Masters that "(b)y separate Summary Order of June 27, 2006, . . I ordered plaintiffs to remove those counts alleging claims for medical monitoring and fear of cancer in their master complaint." See In re World Trade Ctr. Disaster Site Litig., 456 _ F. Supp. 2d 520 _ (SDNY Oct. 17, 2006) (recounting procedural history of plaintiffs' complaints). Prayer for such relief may perhaps be considered as equitable remedies, if causes of action are otherwise proved and if the remedies are held to be appropriate and in accordance with the law. They do not constitute independent causes of action."

162. 2006 U.S. Dist. LEXIS 93639, 2-3 (S.D.N.Y. December 12, 2006). 
epidemic followed. The courts handled huge numbers of claims. Drawing on that experience the state Supreme Court's mass tort manual observes:

Mass torts often require complex fact finding during pretrial, in preparation for trial, or in aid of settlement. Referrals to a neutral may at times be helpful, either by relieving the judge of timeconsuming proceedings or by bringing special expertise to bear on specific issues in dispute. In addition to or in the absence of the fulltime court employed masters, the mass tort judge has discretion, with the approval of the Chief Justice, to appoint special masters... . Settlement activity in mass tort litigation tends to parallel pretrial and trial organization. Consolidated cases tend to generate settlementrelated information at the same time and follow a settlement timetable driven by pretrial and trial deadlines. In general, organization of cases along individual plaintiff lines can be expected to lead to individual settlements, and organization along aggregated lines can be expected to produce aggregated settlements. See The [Federal] Manual for Complex Litigation, Fourth Edition at 167 $182 .^{163}$

Hellerstein's orders spurred a new impulse to settle the cases, which are the object of enormous media attention in New York. Two days after the Special Masters' appointment September 11 Fund Administrator Feinberg weighed in on the issue. Writing in the New York Times, Feinberg lamented the "flood of litigation continues unabated in federal court in Manhattan." 164 He noted that because "none of these 6,000 people who have filed lawsuits received diagnoses of 9/11-related injuries until after the [September 11 Victims' Compensation F] und's filing deadline of Dec. 22, 2003, they were ineligible for compensation. So, reluctantly, they have turned to the courts."165

Suggesting that the September 11 Fund provides a "blueprint" for settlement, Feinberg proposed cobbling together a $\$ 1.5$ billion fund principally taken from the WTC Captive Insurance Company's \$1 billion excess liability coverage. "If you add financial contributions from those contractors and others involved in the litigation, and supplement that with funds from various city charities, a total of at least $\$ 1.5$ billion is available to settle the pending lawsuits-more than sufficient to pay all

163. New JeRsey MASS TORT (NON-ASBEstos) ResourCE BoOK, Administrative Office of the Courts (2005) at 10-11; see The Federal Judicial Center, The Manual for Complex Litigation at 167-82 (4 $4^{\text {th }}$ ed. 2004).

164. Kenneth R. Feinberg, Op-Ed, A Fair Deal for 9/1I's Injured, N.Y. TIMES, Dec. $14,2006, \mathrm{~A}$.

165. Id. 
eligible claims, as well as lawyers' fees and costs." "166

But Feinberg identified no principle, other than the desirability of "compensating victims in distress," for why any special measures should be undertaken. ${ }^{167}$ He states merely that "just as the 9/11 fund should be viewed as a unique public policy response to an unprecedented national calamity, so, too, would this settlement be considered a one-time solution to all remaining physical injury claims occurring at the World Trade Center." 168 But compensating victims in distress is a reason to settle every personal injury claim, regardless of fault, and to compensate every victim of a natural disaster. Suffering alone provides no reason for extraordinary governmental action beyond the $\$ 1$ billion committed to the Captive insurance Fund (which is being eroded by defense costs$\$ 50$ million to December 2006, of which $\$ 32$ million went to law firms). ${ }^{169}$

Every complication in these claims has been seen before. The uncertainty of diagnoses, the uncertainties of liability, the difficulties of proof of extent of exposure and of causal relationship of alleged harm and alleged wrong have been present in hundreds of thousands of asbestos cases processed in every jurisdiction in the country in the 30 years since Judge John Minor Wisdom and the United States Court of Appeals for the Fifth Circuit upheld the landmark product liability claim of asbestos-exposed Clarence Borel. ${ }^{170}$

Feinberg's proposal for a second fund which would be limited to the Captive Fund, and the available insurance was quickly seen to be inadequate. The New York Times reported on December 19, 2006 that " $(t)$ he roughly $\$ 40$ million that was set aside by the federal government to treat rescue workers, volunteers and firefighters who became ill after helping with the 9/11 cleanup and recovery will run out in months." Distribution of the $\$ 75$ million in federal dollars recently obtained had "begun in earnest" only in October 2006. Officials at the Mt. Sinai and Fire Department monitoring and treatment programs said that money could run out by "spring or summer" 2007. Federal officials were reported to project "total annual costs of \$256 million." 171

Area members of Congress objected. They said that Feinberg's proposal was premature because "(d)espite our repeated requests, we still

166. Id.

167. Id.

168. Id.

169. Susan Edelman, Federal Probe of $\$ 1 B$ 9/II Fund, N.Y. POST, December 3, 2006, B.

170. Borel v. Fibreboard Paper Prod. Corp, 493 F.2d 1076 (5th Cir. 1974).

171. Sewell Chan, Money to Treat 9/11 Workers Will Run Out, Officials Say, N.Y. TiMES, December 19, 2006, available at www.nytimes.com (last accessed December 29, 2006). 
have no estimate from the government of how much monitoring, treating and compensating the sick will cost. Doctors from Mount Sinai Medical Center have testified that this crisis will span decades, so compensation is likely to cost much more than the $\$ 1.5$ billion Mr. Feinberg identifies." And, the members of Congress noted,"(d)uring his excellent tenure managing the fund, Mr. Feinberg had unlimited access to money he needed to compensate those who lost loved ones and many others who were injured. A new fund either needs this type of flexibility or an agreed-upon estimate of the total costs based on an independent review." 172

Demonstrating the passion often observed regarding these issues, Representatives Carolyn Maloney (Queens), Vito Fossella (Staten Island), and Senator Robert Menendez (New Jersey) concluded:

Imposing a limit without accurate information about the prospective cost would be a disservice to the heroes who had the misfortune not only of getting sick but also getting sick after the congressionally imposed Victim Compensation Fund deadline. ${ }^{173}$

In February 2007 the World Trade Center Health Panel, a commission appointed by New York City Mayor Michael Bloomberg, reported on problems not only of the Ground Zero cleanup workers but also of area residents and workers. Costs for direct medical treatment and monitoring "could exceed $\$ 392$ million per year." The report addressing the Health Impacts of 9/11 was immediately embraced by the Mayor. It calls for a vigorous campaign to obtain federal funding for treatment, monitoring, and research regarding all those whose health may have been affected by the disaster. ${ }^{174}$

Prominent among the Panel's recommendations is a call for tort immunity for the City and its contractors:

Congress should reopen the Victim Compensation Fund (VCF), authorized by Congress in 2001 , so that victims can quickly get fair compensation without the need to prove liability. At the same time the fund is re-opened, Congress should eliminate the liability of the City and its contractors for claims arising out of the clean-up at the World Trade Center. Since the WTC Captive Insurance Company ("CIC") would no longer be needed, Congress could also liquidate

172. (Rep.) Carolyn B. Maloney, (Senator) Robert Menendez, (Rep.) Vito Fossella, 9/11 Health Lawsuits, Letter to the Editor, N.Y. TIMES, December 21, 2006 at A.

173. Id.

174. World Trade Center Health Panel, Addressing the Health Impacts of 9-11Report and Recommendations to Mayor Michael R. Bloomberg (February 13, 2007); Anthony DePalma, Bloomberg urges More Aid for Those Sickened After 9/11, N.Y. TIMES, February 14, 2007 at B3. 
the $\mathrm{CIC}$ and use its $\$ 1$ billion to help fund the reopened VCF. ${ }^{175}$

Claimants and their advocates will doubtless ask why liability should be capped at such modest sums as Feinberg suggests when the City itself is awash in cash. Fueled by real estate taxes and the financial markets boom, the City is building cash reserves and paying down debt. ${ }^{176}$ Others may grant that $9 / 11$ is properly seen as a national tragedy for which a special solidarity is warranted yet ask why the national government should shoulder the entire burden. Should not New York City and its contractors bear the burden if they mismanaged the clean-up, hedlessly exposing thousands to health hazards arising from work for which no lives were at risk save those of the workers?

It should further be noted that beyond compensation, the tort system provides two important benefits: first, its workings hold up to scrutiny the claims for justice of those who believe that they have been grievously wronged by the City and its contractors; and second, the litigation has driven the City and Congress to address the health needs of its citizens.

The complexity of the litigation has produced delays. Judge Hellerstein has now taken the step of severing liability and damages issues, perhaps uniquely scheduling bellwether damages trials while liability discovery continues. He explains his decision eloquently:

In a few months, six years will have passed since the terrorist attacks of September 11, 2001. Forty-one cases on behalf of forty-two victims remain pending in this Court in the $21 \mathrm{MC} 97$ track, and there are other many other cases in other consolidated tracks arising out of the events of September 11. Yet the resolution of these forty-one cases is not close at hand. The complexity of these cases and the additional procedures required by the sensitive nature of the discovery sought have slowed and complicated this litigation considerably... . Time heals, but time also works against us. Elderly parents who brought actions on behalf of their deceased children will not live forever. Grieving widows and friends waiting for these proceedings to bring them closure may wait too long. And the public, in measures both large and small, share the families' concerns. Many would like to see Plaintiffs' assertions tested in a trial and either found or rejected in a jury verdict. For such persons, long delays are a frustration and denial of the justice sought. Thus I

175. Id.

176. Sewell Chan, Mayor Projects Huge Surplus Fed by Boom in Real Estate, NEw YORK Times, January 26, 2007 (City projects $\$ 3.9$ billion surplus for fiscal year ending June 30, 2007; and $\$ 1.4$ billion surplus next year) available at http://www.nytimes.com/ 2007/04/26/nyregion/26budget.html?amp;ei $=5124 \&$ en $=9 \mathrm{~d} 7 \mathrm{db} 7610 \mathrm{e} 71301 \mathrm{~b} \& \mathrm{ex}=133524$ $0000 \&$ adxnnl=1 \&partner=permalink\&exprod=permalink\&adxnnlx =1 188417668 +F6yPK9MVtKsvy0UkmqkPQ (last accessed Aug, 27, 2007). 
scheduled damages trials. ${ }^{177}$

To this moment one can say that little of tort law has been eroded by 9/11. The September 11 Victim Compensation Fund allowed us to sidestep the special problem of attributing liability to the "enabling tortfeasors" for the criminal acts of the attackers and their victims on the ground. That was the biggest challenge to tort doctrine posed by the events of 9/11. In the case of the Ground Zero workers the law of torts has shown notable strength, providing a coherent approach to the problems. We look next at post $9 / 11$ legislative measures which have mounted a more direct assault on tort.

\section{The Second Wave-Federal Immunity for Products}

The September 11 attacks were soon followed by several criminal attacks in which anthrax was mailed to journalists and members of Congress. It prompted a wave of fear and several deaths. ${ }^{178}$ The synergy of anthrax and 9/11 spurred the fear that anything is possible and that the unimaginable is not only possible but may arrive not only from the clear blue sky but in the mail in plain envelopes. The 9/11 calamity and the anthrax attacks spurred a series of federal legislative measures which afforded liability protections to health care workers, drug, vaccine, and medical device manufacturers. It began with smallpox.

\section{A. The Smallpox Emergency Personnel Protection Act (SEPPA)}

Driven by the post-9/11 fear that the unthinkable was thinkable, the government pressed for and obtained a reversal of the 30 year-old policy of not vaccinating citizens against smallpox disease. In his 2003 State of the Union address the President evoked the then-fearsome image of Saddam Hussein with a stock of viruses at hand. ${ }^{179}$

177. Opinion Supporting Order to Sever Issues of Damages and Liability in Selected Cases, and to Schedule Trial of Issues of Damages, $21 \mathrm{MC} 97$ [AKH] (S.D. N.Y.) July 5, 2007.

178. See Federation of American Scientists, Anthrax Fact Sheet, http://www.fas.org/ biosecurity/resource/factsheets/anthrax.htm (last accessed June 12, 2007).

179. George W. Bush, The State of the Union, January 28, 2003 ("As we fight this war [against terrorism], we will remember where it began-here, in our own country. This government is taking unprecedented measures to protect our people and defend our homeland. We've ... begun inoculating troops and first responders against smallpox, and are deploying the nation's first early warning network of sensors to detect biological attack... Before September the 11 th, many in the world believed that Saddam Hussein could be contained. But chemical agents, lethal viruses, and shadowy terrorist networks are not easily contained. Imagine those 19 hijackers with other weapons and other plans - this time armed by Saddam Hussein. It would take one vial, one canister, one crate slipped into this country to bring a day of horror like none we have ever known. We will do everything in our power to make sure that that day never comes.... I ask 
The smallpox vaccination program of 2003 was unique in public health history. The disease has been eradicated. No one is known to be at risk of infection. But it is possible that scientific research stocks of the virus could be misappropriated, and the vaccination used as a weapon. The benefit of a prophylactic vaccination program therefore is unquantifiable. There could be no benefit. But that there was danger to some in vaccination with the live vaccinia virus vaccine was certain. Yet the government opted not for preparedness to vaccinate, but rather to begin large scale inoculation. ${ }^{180}$

The federal Centers for Disease Control (CDC) in December 2002 announced a program intended to recruit for voluntary smallpox vaccination in the first stage 500,000 health workers. But only 38,000 volunteered in the first 8 months of the program. The military required vaccination of 400,000 soldiers and sailors, and 50,000 civilian employees. $^{181}$ Few civilians volunteered and fortunately few were injured. Because they conducted scrupulous surveillance of military vaccinees the Defense Department medical teams identified previously unsuspected rare complications, such as myopericarditis, which were observed in significant numbers. Active surveillance made possible quick identification of the cardiac hazard and the promulgation of new clinical guidelines for excluding non-military volunteers at risk for such illnesses. $^{182}$ Compensation programs and studies of adverse health effects of a resumed smallpox vaccination program were intensely debated. A very spare program of compensation was enacted. ${ }^{183}$

\section{Liability Limitations and Compensation}

The basic SEPPA scheme is that the U.S. absorbs all liabilityexcept for misconduct in sale, distribution or administration. During the period of a judicially unreviewable administrative declaration by the

you tonight to add to our future security with a major research and production effort to guard our people against bioterrorism, called Project Bioshield. The budget I send you will propose almost $\$ 6$ billion to quickly make available effective vaccines and treatments against agents like anthrax, botulinum toxin, Ebola, and plague. We must assume that our enemies would use these diseases as weapons, and we must act before the dangers are upon us.").

180. Institute of Medicine, The Smallpox Vaccination Program: Public Health in an Age of Terrorism (2005).

181. Id.; see also George W. Conk, Reactions and Overreactions: Smallpox Vaccination, Complications, and Compensation, 14 FORDHAM ENVTL. L.J. 439 (2003).

182. Grabenstein, et al., U.S. Military Smallpox Vaccination Experience, J. AM. MED. Assoc. 288: $3278-3282$ (2003); Mary E. Wright \& Anthony S. Fauci, Smallpox Immunization in the 21st Century: The Old and the New, 289 JAMA 3306, 3308 (2003); Casey, et al., Adverse Events Associated With Smallpox Vaccination in the United States, January-October 2003, JAMA 294:2734-2743 (2005).

183. Conk, supra note 181 , at 440 . 
Secretary of Health and Human Services that there is a "possible" smallpox emergency, all state-law based personal injury tort claims arising out of manufacture, sale, distribution, or administration of a "covered countermeasure" [smallpox (variola) inoculation via the vaccinia virus] are preempted. The claims are replaced by an administrative remedy, which must be exhausted before an action under the Federal Tort Claims Act may be pursued against the United States. Administrative compensation is tied to scheduled injuries for which causal relationship is presumed (similar to the Childhood Vaccine Injury Compensation Program). ${ }^{184}$ Wage loss and medical benefits are secondary to all other benefits and collateral sources including workers compensation, and a death benefit is patterned on (but not duplicative of) the Public Service Officers Benefit program (a Department of Justice administered program). ${ }^{185}$

The Smallpox Emergency Personnel Protection Act of 2003, for liability purposes, deems any "covered person" to be an employee of the United States Public Health Service for whom the United States is vicariously liable, who acts during the period of a "declaration of an actual or potential bioterrorist incident or other actual or potential public health emergency." 186 A covered person is defined as any one who manufactures, distributes, or administers, or sponsors the administration of the smallpox vaccine. ${ }^{187}$ Except for misconduct, the United States assumes all liability for claims arising from smallpox vaccine manufacture, sale and administration. The exclusive remedy by a vaccine or other injured person against such a "covered person" by an injured person is an administrative claim which may be followed by a tort action against the United States under the Federal Tort Claims Act. ${ }^{188}$

That remedy requires exhaustion of an administrative remedy considerably thinner than the National Childhood Vaccine Injury Compensation Program (NCVICP), ${ }^{189}$ which Congress used only as a partial model. SEPPA claims are not administrative matters presented in the U.S. Court of Claims. As in the NCVICP, claims under SEPPA are

184. See National Childhood Vaccine Injury Act of 1986, 42 U.S.C. $\S \S 300$ (aa)-1 through 34 (2002) (Claims under the National Vaccine Injury compensation program are administered by the Office of Special Masters, United States Court of Federal Claims.).

185. 42 U.S.C. $\$ 3796$, et seq (2006) (administered by the Department of Justice, the PSOB provides benefits to public service officers injured in the line of duty). See Bureau of Justice Assistance, http://www.ojp.usdoj.gov/BJA/grant/psob/psob_main.html (last accessed June 12, 2007). See Conk, supra note 181 (recounting the history of the vaccination campaign and the structure of the Smallpox Emergency Act).

186. 42 U.S.C. $\S 233$ (2002) (actions against commissioned officers or employees of the United States Public Health Service).

187. 42 U.S.C. $\$ 233(\mathrm{p})(7)(B)$.

188. Federal Tort Claims Act, 28 U.S.C. $\S 1346$ (b) (2002).

189. 42 U.S.C. $\S \S 300$ aa to aa-34 (1984). 
presumed related if the condition is listed in a table of recognized injuries and if it appears within the recognized time-frame after exposure. ${ }^{190}$ But SEPPA's compensatory plan is more limited than those under the Childhood Vaccine program. SEPPA makes no provision for pain and suffering. That is unlike the NCVIP, which provides for non-economic damages of up to $\$ 250,000 .{ }^{191}$ SEPPA narrowly defines medical benefits as those prescribed by a physician. SEPPA does not cover other necessary services available under the Childhood vaccine program, such as vocational rehabilitation, residential and custodial care to enable a victim to continue living at home. ${ }^{192}$ SEPPA benefits are secondary to all other coverage. ${ }^{193}$ NCVICP provides for attorney's fees to successful claimants. ${ }^{194}$ SEPPA has no such provision.

SEPPA wage loss benefits are secondary to workers compensation. They are capped at $662 / 3 \%$ of "loss of employment income," or $75 \%$ if the claimant has "one or more dependents." There is a $\$ 50,000$ annual limit per year, capped by the amount payable under the Public Safety Officers Benefit Program, ${ }^{195}$ except in the case of permanent and total disability. Wage loss benefits under the Act cease at age 65. ${ }^{196}$ A death benefit is provided, tracking that of the PSOB program, which is adjusted yearly. Any payments for lost income are deducted from the death

190. See Smallpox Vaccine Injury Compensation Program, HeALTH ResouRCES AND SERVICES ADMINISTRATION, http://www.hrsa.gov/smallpoxinjury/table.htm (last accessed October 28, 2006).

191. 42 U.S.C. $\S 300 \mathrm{aa}-15$ (1984).

192. Compare the SEPPA, 42 U.S.C. $\S 239$ (c) ("Medical benefits (a) In general. Subject to the succeeding provisions of this section, the Secretary shall make payment or reimbursement for medical items and services as reasonable and necessary to treat a covered injury of an eligible individual, including the services, appliances, and supplies prescribed or recommended by a qualified physician, which the Secretary considers likely to cure, give relief, reduce the degree or the period of disability, or aid in lessening the amount of monthly compensation.") with the NCVICP $\S 15(\mathrm{a})$ (iii) ("were for diagnosis, medical or other remedial care, rehabilitation, developmental evaluation, special education, vocational training and placement, case management services, counseling, emotional or behavioral therapy, residential and custodial care and service expenses, special equipment, related travel expenses, and facilities determined to be reasonably necessary") and NCVICP $\S 15$ (c) ("Residential and custodial care and service. The amount of any compensation for residential and custodial care and service expenses under subsection (a)(1) shall be sufficient to enable the compensated person to remain living at home.").

193. 42 U.S.C. $\$ 239$ (c) (2002).

194. 42 U.S.C. $\$ 300 \mathrm{aa}(\mathrm{e})(2002)$.

195. 42 U.S.C. $\$ 3796(2002)$.

196. 42 U.S.C. $\$ 239$ (d) (2002). These benefits too are secondary to all other benefits and may be paid in a lump sum or over "multiple years." Cf. NCVIA, 42 U.S.C. $\S 300 a a-15$ (affording compensation for all "actual and anticipated loss of earnings determined in accordance with generally recognized actuarial principles and projections"). 
benefit. ${ }^{197}$

After exhaustion of the administrative remedy the smallpox claimant retains the elective remedy of the Federal Tort Claims Act against the United States which stands in the shoes of the a "covered person" which includes a manufacturer. ${ }^{198}$

SEPPA's narrow compensation scheme, rather than NCVIP, provided the model for the later, more broad-reaching measure: the hyperbolically-named the Public Readiness and Emergency Preparedness Act of 2005 . $^{199}$

\section{The Impact of SEPPA on Tort Claims}

Most of those vaccinated were soldiers and defense department personnel. The Department of Defense civilian employees were assured of workers compensation and the soldiers, who had no choice, were at least assured of medical care, and, potentially service-connected disability. The others, volunteer vaccines were mainly non-federal health workers who subjected themselves to the vaccine's risks in response to employers' requests. ${ }^{200}$

The smallpox vaccination campaign never reached the contemplated 10 million health workers and the vaccine was never offered to the general public. So we saw no injury reports beyond those of health workers, who have presumably pursued workers compensation or smallpox fund claims. But there are a myriad of tort actions that could arise in a mass "pre-event" smallpox vaccination program such as was contemplated but only partially accomplished in the 2003 campaign. $^{201}$

In a mass vaccination campaign (assuming no manufacturing defect, and no available alternative safer vaccine design defect claim) tort claims would center on informed consent. The defendants would be product manufacturers who failed to provide sufficient information, or against medical providers who failed to advise patients at particular risk of complications, ${ }^{202}$ or against the government if in a mass campaign it

197. See 42 U.S.C. $§ 3796$ (2002); see also Bureau of Justice Assistance, Public Safety Officers' Benefits (PSOB) Program, http:/www.ojp.usdoj.gov/BJA/topics/ PSOBProgram.html (last accessed October 28, 2006) (setting benefit limit at $\$ 295,194$ for 2007).

198. 42 U.S.C. $\$ 239$ (h) (2006) (Except as explicitly provided herein, nothing in this part, 42 U.S.C. $\$ \S 239$ et seq., shall be construed to override or limit any rights an individual may have to seek compensation, benefits, or redress under any other provision of Federal or State law.) I read this to say that after exhaustion the FTCA remedy survives.

199. 42 U.S.C. $\$ 247(d)-(6)(d)(2002)$.

200. Conk, supra note $181,479-98$.

201. Id. at 439-40.

202. RESTATEMENT (THIRD) OF TORTS $\S 6$ (1998). 
failed to disclose risks of vaccination. Such claims would have in common failure to provide adequate warning of adverse effects. Under SEPPA, for all such claims, the United States stands in the shoes of the tortfeasor and insures all without cost to the suppliers or recourse against them. (This is unlike the Swine Flu campaign, discussed below, in which the U.S. retained a right of recovery action against negligent manufacturers of vaccines supplied to the U.S.).

Three Johns Hopkins bioethicists have suggested the government, in event of bioweapons attack, dispense in an emergency with the burden of informed consent and offer in its place a program of compensation for adverse effects in order to obtain wide cooperation without compulsory vaccination. ${ }^{203}$ Such an exercise of police power would raise a host of complex and contentious issues, some of constitutional dimension. As suggested by the discussion below of Petty $v$. United States, ${ }^{204}$ such an approach as Faden would, under current law, result in liability against the United States for failure to respect patient autonomy. In the smallpox campaign such informed-consent based claims in a mass campaign would likely have arisen from the incidents of myocarditis and pericarditis. Despite warning by FDA scientists as early as 2001 that coronary inflammation (carditis) was a risk of smallpox vaccination, ${ }^{205}$ it was not until April 2003 when the campaign was well underway and such injuries actually appeared-particularly among young soldiers girding for war-that the FDA Advisory Committee on Immunization Practices warned of the risk. ${ }^{206}$

The SEPPA, with its limited compensation, likely would not have stopped a significant number of such claims in a mass campaign. Such claims would aptly have been addressed to the United States, which

203. Ruth R. Faden, Holly A. Taylor, and Naomi K. Seiler, Consent and Compensation: A Social Compact, for Smallpox Vaccine Policy in the Event of an Attack, 36 CLINICAL INFECTIOUS DISEASE 549 (2003) (In the event of a widespread biological attack involving smallpox, it may not only be morally permissible, but morally obligatory, to dispense with the ordinary requirements of informed consent for vaccination. The government should also commit to educating the public about the vaccine, distributing the vaccine efficiently and fairly, and ensuring access to health care to those who experience adverse events as a result of vaccination. In addition, the government should provide a program of financial compensation for any persons who experience permanent disability as a consequence of vaccination and for the families of those who die as a result of vaccination.).

204. Petty v. United States, 740 F.2d 1428 (8th Cir. 1984).

205. Steven R. Rosenthal, Michael Merchlinsky, Cynthia Kleppinger \& Karen L. Goldenthal, Developing New Smallpox Vaccines, 7 EMERGING INFECTIOUS DisEASEs 6, 920-24 (2001).

206. See Center for Disease Control, Supplemental Recommendations on Adverse Events Following Smallpox Vaccine in the Pre-Event Vaccination Program: Recommendations of the Advisory Committee on Immunization Practices, 52 MORBIDITY \& MORTALITY WEEKLY REPORT 282 (2003). 
purchased the vaccine, prescribed the forms of consent, and, through the CDC, led the campaign. ${ }^{207}$ In the Swine Flu campaign liability was imposed on the United States for its "hard sell" of the influenza vaccine which minimized risks.

During the 2002-2003 smallpox vaccination campaign the Institute of Medicine provided a running commentary throughout the smallpox campaign, issuing a series of "letter reports." In its final report The Smallpox Vaccination Program-Public Health in an Age of Terrorism, the IOM observed:

[T]here is a tension between maximizing participation of those appropriate for and consenting to vaccination-those with appropriate medical and public health responsibilities who are at risk for infection (should it appear) and without true contraindications themselves or in close personal contacts-and minimizing participation by those at high risk for adverse reactions (or in contact with those at high risk for adverse reactions), or those who for whatever reasons do not wish to be vaccinated. ${ }^{208}$

SEPPA only covers those who were vaccinated with the live variola virus pursuant to the declaration of the Secretary of Health. The Act limits coverage to those who receive the vaccine during the period of the declaration. ${ }^{209}$ But the tension to which the IOM refers is a profound and pervasive public health question, as Professor Wendy Parmet has recently thoughtfully explored. ${ }^{210}$ In a true mass campaign, such as in an actual, not a contemplated, emergency, a far more complex set of considerations would come into play than SEPPA-which involved volunteers-confronted.

Government can compel vaccination for public health reasons, relying on the state's right and duty of self-defense. As Justice John Marshall Harlan famously observed a century ago in a challenge to compulsory smallpox vaccination, Jacobson v. Massachusetts: "[U]pon the principle of self-defense, of paramount necessity, a community has the right to protect itself against an epidemic of disease which threatens the safety of its members."211

But individuals remain entitled to know what risks they are

207. Id.

208. National Academy of Sciences, Institute of Medicine, (2005) at 137 (emphasis added).

209. Secretary of Health and Human Services, Declaration Regarding Administration of Smallpox Countermeasures, The Smallpox Vaccination Program, Fed. Reg. 4212, January $28,2003$.

210. Wendy E. Parmet, Informed Consent and Public Health: Are They Compatible When It Comes to Vaccines?, 8 J. Health CARE L. \& POL'y 71 (2005).

211. Jacobson v. Massachusetts, 197 U.S. 11, 12-13 (1905). 
incurring - and to seek exclusion from the vaccination. As Justice Cardozo observed in a case involving a claim made by a woman who asserted she was operated on without her consent: "Every human being of adult years and sound mind has a right to determine what shall be done with his own body."212

This tension between individual liberty and public necessity is inescapable in mass or compulsory vaccination campaigns. But contrary to the suggestions of Faden, et al. ${ }^{213}$ informed consent need not be a casualty of public necessity and urgency - and its provision probably advances the public purpose of widespread cooperation in a mass vaccination campaign. 214 As Prosser observed long ago "some emergencies must be anticipated, and the actor must be prepared to meet them when he engages in an activity in which they are likely to arise." 215

Compulsory vaccination may compel recognition of an individual due process right to be heard, as Lawrence Gostin has suggested in the debate over the Model State Emergency Health Powers Act. ${ }^{216}$ That the process due in "battlefield conditions" may not be that apt for leisurely times does not change the duty. It will call first for preparation and secondly for maximum effort in the moment of crisis. Consent to injurious vaccination induced by deceit may rise to constitutional dimensions and may be explored in the kind of constitutional tort action recognized in Bivens v. FBI. ${ }^{217}$

As the IOM noted the tension extends beyond compulsory vaccination to government-led mass vaccination campaigns. Minimizing the number who must be vaccinated has much to commend it as policy. ${ }^{218}$ Even if the Federal Torts Claims Act did not hold government actors liable on the same ground as private actors, it might be beyond the

212. Schloendorff v. Society of New York Hospital, 105 N.E. 92 (N.Y. 1914).

213. FADEN, ET AL., supra note 203.

214. A subject for historical inquiry is to explore the public education campaign which enabled the New York City Department of Health to succeed in vaccinating without coercion 7 million people- $80 \%$ of the population of New York City-in two weeks after a 1947 smallpox outbreak. See Frieden, et. al, Cardiac Deaths after a Mass Smallpox Vaccination Campaign-New York City 1947, 52 MORBIDITY AND MORTALITY WEEKLY REPORT No. 39 (October 2, 2003).

215. PROSSER ON TORTS, supra note 95, at § 138.

216. Lawrence O. Gostin, When Terrorism Threatens Health: How Far Are Limitations on Personal and Economic Liberties Justified?, 55 FLA. L. REv. 1105 (2003).

217. Bivens v. Six Unknown Named Agents of Federal Bureau of Narcotics Agents, 403 U.S. 388 (1971) (This case recognized a constitutional tort action for unreasonable search of dwelling. Non-informed-consensual vaccination by federal agents may give rise to a constitutional tort action for invasion of privacy.).

218. See IOM Report, supra note 208, at 17-18 (This report discussed ring vaccination-in which mass inoculation is avoided, and vaccination is carried out among the ring of people surrounding the infected person. Surveillance and containment are options preferred over mass vaccination.). 
power of Congress to bar such an action in tort for deceit, if the government, by virtue of misleading information, has obtained consent to bodily invasion. If we recognize the right of recourse as a central element of civil society, then justification of the incursions on individual autonomy imposed in the name of emergency requires careful demonstration not simply of the nature and extent of the emergency but of the opportunity to plan in advance of its occurrence.

Overreactions such as the 2003 smallpox vaccination campaign nonetheless provided valuable training regarding the lack of public health readiness for unexpected microbial attacks, whether natural or criminal. David Rosner and Gerald Markowitz, two of our most important historians of public health, draw three lessons from 9/11: that the success of public health responses in New York was due less to planning than to the strength of its existing, historic infrastructure of health services, laboratories, and personnel; that we need a much more expansive understanding of mental health services; and that "failure to communicate honestly about uncertainty is a big mistake." 219

It is far beyond the scope of this paper to resolve these issues of fundamental rights in conflict when compulsion confronts personal integrity. But it is important to observe that not every person needs to be vaccinated in a mass campaign. The New York City 1947 effort successfully contained the smallpox outbreak with $80 \%$ vaccination of the population-over 6 million people in 28 days. $^{220}$ But as the IOM suggests "ring vaccination" may be an effective alternative to mass vaccination. State laws that permit individual exception to mandatory vaccination for those at identifiable risk recognize that. ${ }^{221}$ Herd immunity - a barrier against wide spread of contagious disease-is achieved with less than $100 \%$ participation because certain persons are more likely transmitters of disease, and therefore more important vaccinees than are others. As a prudential matter, the achievement of a high degree of participation in a mass campaign for eradication of disease-and especially in a true emergency-requires trust and cooperation by citizens. That includes willingness to take risk for the community good. A wise approach might be to recognize that even where great risk of disease spread can be identified prudence and reasonable caution counsel that an individual is entitled to be heard on a

219. See generally David Rosner and Gerald Markowitz, ARE We Ready? PUBlic HeALTH SinCE 9/11 (2006).

220. T. Frieden, et al.,Centers for Disease Control, Cardiac Deaths After a Mass Smallpox Vaccination Campaign - New York City, 1947, 52 MORBIDITY AND MORTALITY WEEKLY REPORT 933 (2003).

221. Lawrence O. Gostin, School Vaccination Requirements: Historical, Social, and Legal Perspectives, 90 KY. L.J. 831, 873-74 (2002). 
claim of exemption even from mandatory mass vaccination.

SEPPA covered a narrow slice. It was a unique program in which volunteers were elicited for a vaccine which certainly carried risks but no risk of disease without vaccination could be identified or estimated. In such circumstances of the most speculative need, there is no reason to forego the fullest measure of individual choice and informed consent. Any failure to inform recipients should remain actionable-particularly against the government architects of the program. In such instances, the availability of a tort option seems essential to vindicate individual freedom and to constrain government impulse driven by hysteria or misplaced ideological fervor, as may have been the case in the Presidential boost given to smallpox vaccination in the 2003 run-up to the invasion of Iraq.

In true mass inoculation settings - after the outbreak of an identifiable potentially pandemic disease ${ }^{222}$ the hard sell will be more tempting. That is beyond the scope of this project, except to the extent that the discussion of the historical experience with swine flu may be instructive. Underlying the IOM's discussion of "ring strategies" is recognition of the high value of patient choice and voluntary risk assumption. Alarmist approaches-like that in the 1976 swine flu campaign-lead to unnecessary risks of harm. I think it will aid the clarity and caution with which such issues as emergency pandemic influenza vaccination are addressed if we see the right of informed patient autonomy and recourse against wrongdoers as essential parts of ordered liberty.

\section{B. The Public Readiness and Emergency Preparedness Act of 2005}

The funding for development and acquisition of "strategic stockpiles" by the federal government authorized by BioShield 2004 left a question: how would we solve the often-bruited problem of vaccine development, a market from which the giant pharmaceutical companies have generally shied away. Legislative initiatives focused on promises of liability protection, extension of patent terms or other exclusive rights, and anti-trust protections, measures which were said to be necessary incentives to get "big pharma" to enter the fray to develop and produce products such as vaccines to counter the feared pandemic of avian

222. See, e.g., Dep't Health and Human Services, Health and Human Services Pandemic Flu Influenza Plan (November 2005). (Prior to onset the United States will develop public stockpiles for distribution to health providers anti-viral drugs sufficient to treat $25 \%$ of the U.S. population, according to predetermined priority groupings. At the onset of a pandemic influenza outbreak the federal government will work with the pharmaceutical industry to develop an effective vaccine.). 
influenza, or another bioweapon attack like the anthrax incidents. ${ }^{223}$

If the SEPPA is a saber, narrowly drawn-limited to a single product with generally well known risks, ${ }^{224}$ and for a limited time-then the Public Readiness and Emergency Preparedness Act of 2005 is a blunderbuss. PREPA was passed without hearings or mark-up as a rider to the pre-Christmas defense appropriations bill. Its coverage was described at its December 30, 2005 signing principally as for the threat of pandemic avian influenza. ${ }^{225}$

In fact the Public Readiness Act is far broader than the presidential signing statement presents. It is not limited to the products in the "strategic stockpile." The "emergencies" to which its "liability protections" 226 are provided not only for products used in emergencies in

223. There were no significant legislative studies nor were there extensive hearings to explore the problem. The Senate Committee on Health, Education, Labor, and Pensions hosted one session on liability protections, patent term extensions, and anti-trust protections for vaccines, etc. See Roundtable Discussion: Senate Subcommittee on Bioterrorism and Public Health Preparedness Title: Roundtable Discussion: When Terror Strikes-Preparing an Effective and Immediate Public Health Response: Hearing Before the S. Comm. on Health, Education, Labor, and Pensions, 109th Cong. 193 (2005) July 14, 2005. Audio recording and written statements are available at http://help.senate.gov/Hearings/2005_07_14_b/2005_07_14_b.html (last visited October $29,2006)$.

224. Because smallpox vaccination had not been universal until 1972, when civilian vaccination ended, a large database was available when vaccinations resumed. Relying extensively on the classic epidemiological reports of Professor J. Michael Lane, who had studied smallpox vaccination programs for 50 years, the Advisory Committee on Immunization Policy (ACIP) recommended in June of 2001 that smallpox vaccination need only resume when an actual terrorist release of the virus was reported. Citing the risks of vaccine-related illness, the ACIP also recommended development of a new, safer smallpox vaccine. Reviewing the reported complications associated with first-time vaccinia vaccination, the ACIP identified the following principal risks: 1) accidental inoculation (spread from one part of the vaccinee's body to another, or one person to another) for 529.2 people per million vaccinations; 2) generalized vaccinia (systemic illness due to the vaccinia virus) for 241.5 million people; 3 ) eczema vaccinatum (skin rashes among those with eczema history) for 38.5 million people; 4) progressive vaccinia (severe necrosis at the vaccination site) for 12.3 million people; and 5) postvaccinial encephalitis for 12.3 million people. The last two risks were considered potentially fatal. See Lisa D. Rotz, Debra A. Dotson, Inger K. Damon \& John A. Becher, Vaccinia (Smallpox) Vaccine, Recommendations of the Advisory Committee on Immunization Practices (ACIP), 50 MWWR 1, 1-25 (2001).

225. President's Statement on Signing of H.R. 2863, the "Department of Defense, Emergency Supplemental Appropriations to Address Hurricanes in the Gulf of Mexico, and Pandemic Influenza Act, 2006," 41 WeEkLY CoMP. Pres. DoC. 1918 (Dec. 30, 2005) ("Today, I have signed into law H.R. 2863, the 'Department of Defense, Emergency Supplemental Appropriations to Address Hurricanes in the Gulf of Mexico, and Pandemic Influenza Act, 2006.' The Act provides resources needed to fight the war on terror, help citizens of the Gulf States recover from devastating hurricanes, and protect Americans from a potential influenza pandemic.").

226. Public Readiness and Emergency Preparedness Act Public Readiness and Emergency Preparedness Act, 42 U.S.C. $\$ 247(d-)(6)(d)(a)(1)$ (2006) ("Subject to the other provisions of this section, a covered person shall be immune from suit and liability 
the common sense. It extends to any determination by the Secretary that "a disease or other health condition or other threat to health constitutes a public health emergency, or that there is a credible risk that the disease, condition, or threat may in the future constitute such an emergency.",227 The statute permits DHHS to grant tort immunity without any requirement that reasonable care have been used in the development and manufacture of the product.Even after its unreviewable administrative approval for emergency use and its designation as a "covered [i.e. tort immune] countermeasure," PREPA does not require that manufacturers, designers, or providers continue to study or work to improve the product. Manufacturing defects, design defects, inadequate warnings, and even reckless disregard of safety by manufacturers thus are all immunized by PREPA. ${ }^{228}$

PREPA's compensatory provisions adopt those in SEPPA. The act relies on a table of covered injuries, like SEPPA and NCVICP, discussed above. But compensation is available only if there is "direct causation of a covered injury." A covered injury, which is death or serious injury, is only one listed in a table of "covered injuries" by the Secretary of Health who may only make such a determination based on "compelling, reliable, valid, medical and scientific evidence.",229

PREPA's grossly misleading popular name promises "[t]argeted liability protections for pandemic and epidemic products and security countermeasures." But it extends its immunizing reach to any product which is declared a "covered countermeasure" and which is used during the period of a (non-judicially reviewable) declaration by the Secretary of Health that

a disease or other health condition or other threat to health constitutes a public health emergency, or that there is a credible risk that the disease, condition, or threat may in the future constitute such an emergency, the Secretary may make a declaration, through publication in the Federal Register, recommending, under conditions as the Secretary may specify, the manufacture, testing, development, distribution, administration, or use of one or more covered countermeasures, and stating that subsection (a) is in effect with respect to the activities so recommended. ${ }^{230}$

under Federal and State law with respect to all claims for loss caused by, arising out of, relating to, or resulting from the administration to or the use by an individual of a covered countermeasure if a declaration under subsection (b) has been issued with respect to such countermeasure.").

227. Public Readiness and Emergency Preparedness Act $\S 247 d-6(d)(b)$.

228. 42 U.S.C. $\S 247 \mathrm{~d}-6 \mathrm{~d}$ (b)(1) (2006).

229. 42 U.S.C. $\$ 247 \mathrm{~d}-6 \mathrm{e}(\mathrm{b})(4)(2006)$.

230. See id. (emphasis added). 
Subsection (a) provides that during the declaration's effective period and within the geographic area (which may be a specification that such subsection applies without geographic limitation) a covered person shall "be immune from suit and liability under Federal and State law with respect to all claims for loss caused by, arising out of, relating to, or resulting from the administration to or the use by an individual of a covered countermeasure." 231

Immunity extends to any "qualified pandemic or epidemic product" that may diagnose, cure, treat, or even "mitigate" any "serious" disease or condition-even if the product is merely the object of study for possible use. ${ }^{232}$ PREPA immunity is gained if the product is used during the period of the declaration, for a condition and for a population specified in the declaration, decisions which are unreviewable by any court. $^{233}$

There is a "bad actor" exception to PREPA, but one would have to be a very bad actor to qualify. The Public Readiness Act allows a right of action only where there is "clear and convincing evidence (of) willful misconduct by each covered person sued and that such willful misconduct caused death or serious physical injury." But willful misconduct may be further limited by regulation and in the event of a regulated product

such act or omission shall not constitute "willful misconduct" for purposes of subsection (d) if--

(I) neither the Secretary nor the Attorney General has initiated an enforcement action with respect to such act or omission; or

(ii) such an enforcement action has been initiated and the action has been terminated or finally resolved without a covered remedy.

Any action or proceeding under subsection (d) shall be stayed during the pendency of such an enforcement action. ${ }^{234}$

In the unlikely event that such conditions have been met, the Preparedness Act provides that the exclusive action shall be before a three judge court in the United States District Court for the District of Columbia, that there shall be detailed pleading, with medical records and physicians affidavits attached, and that no discovery shall be permitted until the defendant(s) have had the opportunity to bring a motion to

231. See 42 U.S.C. $247 \mathrm{~d}-6 \mathrm{~d}(\mathrm{a})(1)$ (2006).

232. Public Readiness and Emergency Preparedness Act § 247d-6d(i) (2006).

233. See id. $\S 247 \mathrm{~d}-6 \mathrm{~d}(\mathrm{~b})(7)$ ("No court of the United States, or of any State, shall have subject matter jurisdiction to review, whether by mandamus or otherwise, any action by the Secretary under this subsection.").

234. Id. § 247d-6d(c)(5)(A)(i) (2006). 
dismiss. $^{235}$ And of course there shall be full credit given to such a wrongdoer for all benefits received from collateral sources. ${ }^{236}$

Such an "emergency" measure has no precedent in the common law or in the codifications of the common law principle that reasonable care is determined based on the exigencies of the circumstances, of which emergency is one. Emergency has posed no special doctrinal problems for the law of torts. Emergency has simply been understood to be one of the facts which must be taken into account in determining what constitutes reasonable care under the circumstances. ${ }^{237}$ This measure, which substitutes a highly limited remedy for direct responsibility for negligence and recklessness by a wide swath of actors-sellers, manufacturers, professionals, and governmental actors-reveals a deep distrust of tort law.

Virtually unconditional authority is given to the Secretary of Health to cloak medical personnel and product manufacturers, sellers, or providers in immunity. The Secretary need simply declare (without fear of judicial review) that there is a "credible risk" that a disease, condition or threat "may in the future constitute such an emergency" threat to public health. ${ }^{238}$ There are no criteria, no requirements, no preconditions, no judicial review for such an administrative determination, and state tort law is pre-empted. ${ }^{239}$ The Secretary need merely specify the location, the duration, the protected population, and the targeted diseases or health conditions. He then may "recommend ... under [such] conditions as [he] may specify, the manufacture, testing, development, distribution, administration, or use of one or more covered countermeasures, and stating that subsection (a) is in effect with respect to the activities so recommended.",240

The passage of the Act is said to provide an incentive to relieve the fear of liability and spur vaccine production. But the protected products are not limited to vaccines, for which the lack of recurrent markets may make problematic underwriting and risk estimation. PREPA authorizes an unfettered Secretary of Health to immunize use in a declared emergency of any product that "may mitigate" any disease or

235. $\S 247 \mathrm{~d}-6 \mathrm{~d}(\mathrm{c})(5)(\mathrm{A})(2006)$.

236. See id. § 247d-6d(e)(1) (2006) ("Any action under subsection (d) shall be filed and maintained only in the United States District Court for the District of Columbia").

237. DOBBS, supra note 152, at 129-32 (stating, although common law has taken into account emergency to a circumstance, emergency and Good Samaritan statutes have sometimes gone far beyond by creating immunities, defenses, or lower standards of care).

238. 42 U.S.C. $\$ 247(d)-(6)(d)(2006)$.

239. Public Readiness and Emergency Preparedness Act 42 U.S.C. $\S 247(d)-$ (6)(d)(b)(8) (2006).

240. $I d . \S 247 \mathrm{~d}-6 \mathrm{~d}(\mathrm{~b})(1)$. 
condition. $^{241}$ Even in the case of vaccines such incentives as PREPA provides are the product of long, plaintive cries of wolf at the door. But Michelle Mello and Troyen Brennan of the Harvard School of Public Health have demonstrated that the rate of adverse events from influenza vaccine is low and stable. The product liability and other litigation arising from the millions of influenza injections given each year is trivial in number and effect. ${ }^{242}$

Direct government purchase of vaccine for stockpiling would afford the manufacturers the government contractor defense, as the government's selection of materials to buy would likely be seen as a discretionary decision which provided derivative protection to the seller who complies with government's discretionary design choices, as in Boyle v. United Technologies. ${ }^{243}$ Particularly worrisome is that during manufacture and stockpiling, but before use, no duty is imposed to continue to study and test the product so that it meets the usual safety and efficacy standards. Such stockpiling is under way, funded by the $\$ 6.5$ billion Bioshield Act of 2004. ${ }^{244}$ (Biosafety related government spending has now reached a total of $\$ 36$ billion since the anthrax attacks. $)^{245}$ Yet recent press accounts indicate that progress on the stockpiles on is slow. It is described by Rep. Christopher Shays as "[a] torturous labyrinth of federal fiefdoms into which billions disappear. . . Yet few antidotes have yet to emerge."246

It bears noting that the SAFETY Act of 2002 provides the same defense to suppliers of "qualified anti-terrorism technology" to the

241. Id.

242. Michelle M. Mello \& Troyen A. Brennan, Legal Concerns and the Influenza Vaccine Shortage, 294 JAMA 1729, 1817 (2005) ("Analyzing VAERS data on influenza vaccine-associated injuries, [the National Vaccine Advisory Committee] NVAC found that between 1990 and 1995 , for every 10 million doses delivered to adults, there were 5 deaths, 30 serious adverse events, and 135 non-serious adverse events. A more recent analysis determined that 501 instances of GBS were reported to the VAERS from 1990 through June 2003. Reports of GBS declined from 17 cases per 10 million vaccinations (1993-1994) to 4 cases per 10 million vaccinations (2002-2003). Rates of other adverse events were stable at about 15 cases per 10 million doses (2002-2003).”).

243. Boyle v. United Techs. Corp., 487 U.S. 500 (1988).

244. Project BioShield Act of 2004, Pub. L. No. 108-276, 118 Stat. 835 (2004) ("The Secretary, in coordination with the Secretary of Homeland Security (referred to in this section as the 'Homeland Security Secretary'), shall maintain a stockpile or stockpiles of drugs, vaccines and other biological products, medical devices, and other supplies in such numbers, types, and amounts as are determined by the Secretary to be appropriate and practicable, taking into account other available sources, to provide for the emergency health security of the United States, including the emergency health security of children and other vulnerable populations, in the event of a bioterrorist attack or other public health emergency.").

245. Enough Biodefence, NATURE, Nov. 2, 2006.

246. Eric Lipton, Bid to Stockpile Bioterror Drugs Stymied by Setbacks, N.Y. TIMES, Sept. 18,2006 . (online edition). 
Department of Homeland Security. ${ }^{247}$ That program is now well underway providing the benefit of that defense to suppliers. ${ }^{248}$

PREPA is thus the broadest attack on tort. Though it is limited to products for which the Secretary of Health has issued a time-limited (though nothing says how limited) declaration, for use in emergency, and applies only to such use, it immunizes a wide band of actors and products without any need to show they exercised reasonable care. Indeed, reckless disregard is immunized. Once declared a "qualified pandemic or epidemic product" no duty is imposed on a manufacturer to further study, test, or develop the product, for which a long period of time may have elapsed between declaration and "emergency" use. No test of reasonable care, safety, or efficacy at the time of its designation as a "qualified" product is required to be shown to the Secretary, who may, unreviewably, recommend it for designated purposes the breadth of which lies in the Secretary's sole discretion.

Though the practical impact of PREPA cannot yet be known, the measure has broad potential to immunize negligent and reckless conduct because it can be used to immunize the makers vaccines, drugs, biologics, and medical devices regardless of their degree of testing, safety and efficacy, even if reasonable efforts to assure safety were made neither before nor after the designation of the product as a "qualified pandemic or epidemic product." It is therefore not surprising that there is pending a measure which would repeal the PREPA.

\section{Counterpoint to PREPA-S. 2291-The Responsible Public Readiness and Emergency Preparedness Act}

Senators Kennedy, Dodd, Harkin and Bingaman have proposed repeal of the Public Readiness Act. Their measure, S. 2291, titled the "Responsible Public Readiness and Emergency Preparedness Act," was introduced in the $109^{\text {th }}$ Congress. ${ }^{249}$ It would create the National Biodefense Injury Program. It too would indemnify manufacturers and administrators of certain "covered countermeasures" and creates an administrative remedy, and a tort option. ${ }^{250}$ Except for the "grossly

247. SAFETY Act of 2002, 6 U.S.C. $\$ \S 441-44$ (2002) (providing DHS suppliers with federal preemption, an exclusive federal remedy, and the government contractor defense).

248. See Dep't Health Human Services Act, https:/www.safetyact.gov (last accessed June 27, 2007).

249. Despite declarations of intent by the Democratic Senate leadership, the measure has not yet been reintroduced in the 110 th Congress. See Responsible Public Readiness and Emergency Preparedness Act, S. 2291, 109th Cong. (2006) [hereinafter RPREP].

250. Id. 
negligent, reckless and willful wrongdoers," 251 the government honors the right of civil recourse, it indemnifies, assumes all liability, and stands in the place of makers, sellers, and administrators of the approved measures

regardless of whether-(I) the cause of action seeking compensation is alleged as negligence, strict liability, breach of warranty, failure to warn, 10 or other action; or (ii) the covered countermeasure is designated as a qualified anti-terrorism technology under the SAFETY Act (6 U.S.C. 441 et seq.). ${ }^{252}$

S. 2291's range of "covered countermeasures" is far narrower than PREPA's. Protection is afforded only to smallpox vaccine or a drug that

the Secretary determines to be a priority ... to treat, identify, or prevent harm from any biological, chemical, radiological, or nuclear agent identified as a material threat . . . or to treat, identify, or prevent harm from a condition that may result in adverse health consequences or death and may be caused by administering a drug, biological product, or device against such an agent; ... or is authorized for emergency use under [21 U.S.C. 360bbb-3] of the Federal food, Drug, and Cosmetic Act, ${ }^{253} .$. so long as the manufacturer of such drug, biological product, or device has-(AA) made all reasonable efforts to obtain applicable approval, clearance, or licensure; and $(B B)$ cooperated fully with the requirements of the Secretary under [the Emergency Use Amendments], or (bb) approved or licensed solely pursuant to (21 CFR 314.1, et seq.) [applications or abbreviated new drug applications]; and (III) is specified in a declaration under paragraph (2). ${ }^{254}$

251. See id. $\S 4$.

252. See id. $\S 4$ (proposing the addition of Subsection (D), which states "Liability of the United States-The United States shall be liable under this subsection with respect to a claim arising out of the manufacture, distribution, or administration of a covered countermeasure regardless of whether (i) the cause of action seeking compensation is alleged as negligence, strict liability, breach of warranty, failure to warn, or other action; or (ii) the covered countermeasure is designated as a qualified anti-terrorism technology under the SAFETY Act (6 U.S.C. 441 et seq.) (2006)."' Additionally, the Act proposes the addition of Subsection (E), which states "GOVERNING LAW-Notwithstanding the provisions of section 1346(b)(1) and chapter 171 of title 28, United States Code, as they relate to governing law, the liability of the United States as provided in this subsection shall be in accordance with the law of the place of injury.").

253. See Authorization of Emergency Use of Anthrax Vaccine Adsorbed for Prevention of Inhalation Anthrax by Individuals at Heightened Risk of Exposure Due to Attack With Anthrax; Availability, 70 Fed. Reg. 5452 (Feb. 2, 2005).

254. REREP, supra note 249 , at $\S 4$ (titled "Indemnification for Manufacturers and Health Care Professionals Who Administer Medical Products Needed for Biodefense," which would amend Section 224(p) of the Public Health Service Act (42 U.S.C. 233(p))) (emphasis added). 
S. 2291's promise of compensation is much more reliable than that of the PREPA because the draft Act specifically directs that the National Academy of Sciences' Institute of Medicine (IOM) be hired to make determinations of what injuries should be included in the table of injuries by using the "best available evidence" 255 rather than affording compensation only in the face of "compelling, reliable, valid, medical and scientific evidence," as the Public Readiness Act provides. The requirement of "compelling" evidence is sure to narrow the scope of table injuries recognized under PREPA.

S. 2291 is designed to restore the ability to challenge the conduct of actors as to its reasonableness, as the law of torts customarily provides. It is recognition, unfortunately by a legislative minority, that ordinary care is an obligation of citizenship, and that recourse against those who fail that measure, is a right of citizenship.

\section{Whom Should We Compensate?}

S. 2291's narrow scope, with its emphasis on "priority" products, is complemented by greater clarity of purpose: not only to encourage production, distribution and administration of such measures by protecting them from liability, but also to " $(t) o$ encourage individuals to consent to the administration of a covered countermeasure by providing adequate and just compensation for damages related to death and such injuries, disabilities, illnesses, or conditions." 256

The phrase "encourage individuals to consent" makes the point that the compensation offered here is a prudential benefit to advance the public health, not a payment meant to compensate for injury wrongly inflicted. Rather, it is intended to achieve benefits such as herd immunity, the principle that every person who is vaccinated aids the rest of the community because she is no longer a source of disease replication and transmission. ${ }^{257}$ In order to encourage such cooperation, compensation is offered. S. 2291 makes clear that this is not tort damages but rather prudential compensation to encourage voluntary compliance with a course of action that may benefit others while carrying some risks to the volunteer. ${ }^{258}$

255. Id. at $\S 3(\mathrm{a})(4)$, (entitled "Injury Table," and discusses evidence this way: "[T]he best available evidence, including information from adverse event reporting or other monitoring of those individuals who were administered the countermeasure, whether evidence from clinical trials or other scientific studies in humans is available.").

256. Id. at $\S(\mathrm{B}) \mathrm{iii}$.

257. Arthur Allen, For the Good of the Herd, op-ed, N.Y.TIMES, January 25, 2007, A.

258. RPEP at $\S 3(\mathrm{a})(4)(\mathrm{B})(\mathrm{iii})(\mathrm{II})$ (titled "Program Goals," and seeks to "encourage individuals to consent to the administration of a covered countermeasure by providing adequate and just compensation for damages related to death and such injuries, 
The authors of PREPA did not recognize this distinction. The Public Readiness Act is over-broad, both in its immunity provisions and in whom it compensates. Emergency circumstances affect not the standard of care; but rather, what it is reasonably possible to deliver in the circumstances. Thus the Food Drug \& Cosmetic Act provides for Emergency Use Authorizations and other regulatory relief, such as permitting Accelerated New Drug Approval, which depart from customary measures of safety and effectiveness such as clinical trials, allowing animal and laboratory studies to serve as a basis for emergency use or accelerated approval. ${ }^{259}$ Such permission to use when appropriately granted will lead to greater adverse effects than longer study would prevent. But, assuming genuinely informed consent, and ongoing responsible stewardship by developers and manufacturers to address safety and efficacy issues, these are not tortious injuries. We have no obligation to compensate those sickened by adverse effects suffered due to such reasonable emergency approvals.

The now venerable $\S 402 \mathrm{~A}$ of the Second Restatement of Torts, in Comment $\mathrm{K}$, makes a plain statement of the rule: so long as there is reasonable warning of irremediable dangers there is no liability. ${ }^{260} \mathrm{~S}$. 2291 properly frames its relief as a matter of public health-based incentives, to "encourage" people to take advantage and to assume the risks of such measures. If we are to defend tort we should defend tort principles, and that is that compensation is owed only to those who have suffered a wrong. Other compensation should be recognized as a benefit to those who assume risk to advance a public purpose.

Those injured by products properly authorized for emergency use, properly manufactured products, the limited testing of which is justified by exigent circumstances as described in the Food Drug \& Cosmetic Act, and for which the recipient's informed consent has been given, ${ }^{261}$ have not been wronged-unless, as S. 2291 recognizes, the manufacturer has failed to continue to study its products and to advance testing to obtain full regulatory approval. That affirmative duty, well-recognized in tort law, is spurned by PREPA's immunizing Secretarial wand. ${ }^{262}$ The only such product approved to date, AVA anthrax vaccine, is seen in the FDA's authorization $^{263}$ to be the subject of good faith and extensive

\footnotetext{
disabilities, illnesses, or conditions.").

259. 21 C.F.R. $\$ 314.101$, et seq (2007).

260. RESTATEMENT (SECOND) OF TORTS, $\S 402 \mathrm{~A}, \mathrm{cmt}$. K (1977).

261. 21 U.S.C. $\$ 360 \mathrm{bbb}-3(2007)$.

262. When an actor's prior conduct, even though not tortious, creates a continuing risk of physical harm of a type characteristic of the conduct, the actor has a duty to exercise reasonable care to prevent or minimize the harm. See RESTATEMENT (THIRD) OF TORTS § 39 (Proposed Final Draft No. 1, 2005).

263. See Authorization of Emergency Use of Anthrax Vaccine Absorbed for
} 
consideration of the special circumstances presented by the threat of an attack using weaponized anthrax.

PREPA fails not only to require the kind of findings provided in the Emergency Use Authorization act but it also does not make clear the basis for its offer of compensation. It confuses tort-replacement remedies and public health benefits with tort forgiveness. S. 2291 explains that its compensation mechanism is due to the need to encourage compliance with public health measures which present risks beyond the ordinary. ${ }^{264}$ Compensation without a wrong is foreign to tort. When we choose for policy reasons to afford it we should make clear, as does S. 2291, why we are departing from the tort norm.

V. Historic Experience with Pandemic Flu Prophylaxis--The Swine Flu Experience and the Federal Tort Claims Act

Even PREPA does not immunize the United States. It works no repeal of the Federal Tort Claims Act. If drugs or vaccines in the national strategic stockpile are supplied by it for use the United States will remain potentially liable for the defects in those products on the basis provided in the FTCA. In a genuine large scale emergency, the drugs and vaccines stockpiled will have been purchased by the government, allowing suppliers the government contractor defense even if PREPA is repealed. Since the basis for government liability is negligence, or another basis on which a private person would be liable, there are few doctrinal constraints on government liability (other than the discretionary action exception), especially since the widespread view is that product liability law has merged with the general body of negligence law. ${ }^{265}$ This invites a review of the last time we confronted a potential outbreak of pandemic influenza - and our response to it which was for the government to assume all liability under the Tort Claims Act.

In 1976 the federal government undertook to vaccinate the entire

Prevention of Inhalation Anthrax by Individuals at Heightened Risk of Exposure Due to Attack With Anthrax, 70 Fed. Reg. at 5452 (Feb. 2, 2005).

264. $\S($ b) iii.

265. See, e.g. Aaron D. Twerski, Chasing the Pot of Gold at the End of the Rainbow, MARQ. L. REV. (forthcoming 2007); DAN DOBBS, THE LAW OF TORTS 355 (2000) (" $[C]$ ourts have now generally adopted a risk-utility test to determine whether a harmful design is also a defective design. When the risk utility test is applied, the courts seem to be requiring negligence or at least some similar species of fault."); William Powers, Jr., $A$ Modest Proposal to Abandon Strict Products Liability, 1991 U. ILL. L. Rev. 639, 654 (1991) ("[C]ourts have had to expend considerable energy trying to explain how defectiveness under risk-utility differs from negligence. The effort has been far from successful."); Alan Schwartz, The Case Against Strict Liability, 60 FordHAM L. REv. 819,824 (1992) ("Products designs are currently regulated under a negligence test: a design is defective if, in the opinion of the jury, the design creates risks in excess of benefits."). 
population but halted the effort after 45 million had been vaccinated when the outbreak proved limited and unexpected complications arose. The United States required insurance from the vaccine manufacturers it immunized in case their manufacture was negligent or in breach of contract. The United States accepted liability for the most serious and unpredicted injuries, litigated other claims on the basis of prevailing (state) product liability law, and was found liable for inadequacies in its "hard sell," minimally informative "informed consent" forms. ${ }^{266}$ The claims were all handled under the Federal Tort Claims Act, thus embracing state tort law, and recognizing the right of civil recourse for wrongdoing. ${ }^{267}$ Despite the apparent emergency which impelled the campaign, the United States sought for itself no immunity beyond its ordinary protection under the Federal Tort Claims Act for discretionary acts.

When a cluster of especially virulent influenza cases appeared among soldiers at Ft. Dix, New Jersey in 1976, public health scientists identified the new strain as a swine flu-a strain of influenza genetically similar to that which caused the world-wide influenza pandemic of 1918 . President Gerald Ford, at the urging of the Center for Disease Control $[C D C]$, announced the government would "immunize 200 million Americans"-the entire population-against the Swine flu, the Avian flu pandemic threat of the day. In the end 45 million civilians and 2.5 million soldiers and dependents received the vaccine from October through mid-December, $1976 .^{268}$

The program was slowed by a variety of problems including late delivery of vaccine and the non-appearance of new cases of the Swine flu strain that had prompted the campaign. But the coup de grace was delivered when Guillain-Barre Syndrome, a rare paralytic disease, began to appear among vaccinees. Eventually the rate among vaccinees was shown to be $8.3 / \mathrm{million} / \mathrm{month}$ compared to $0.7 / \mathrm{million} / \mathrm{month}$ in the general population. Though the cases were few, the "relative risk" was high. When the trend first appeared-thanks to active surveillance by health officials who had not expected to see the complication--the CDC quickly concluded that the vaccination campaign should halt. ${ }^{269}$

150 million doses of vaccine had been ordered. The four manufacturers-Merck, Sharp, Wyeth and Parke Davis-were paid $\$ 54,000,000$ for the vaccine itself. The government absorbed as part of the purchase price the manufacturers' insurance premiums for

266. See infra discussion of Petty v. United States, 740 F.2d 1428 (8th Cir. 1984).

267. 42 U.S.C. § 2674-2680 (2002).

268. ARTHUR M. Silverstein, PuRe Politics and Impure SCIENCE-The Swine Flu AFFAIR, 113, et passim (1981).

269. Id at 120-124. 
$\$ 55,000,000$ in product liability insurance, and advanced an escrow of $\$ 10$ million for the $\$ 2.5$ million self insured retention of each insured. The total budget for the campaign was $\$ 135,000,000 .{ }^{270}$

\section{A. Swine Flu Vaccine Product Liability Claims}

In the National Swine Flu Immunization Program of 1976, Congress immunized the vaccine manufacturers for all claims but the government's own. ${ }^{271}$ The United States stood in the manufacturers place and assumed defense and indemnification of all liability claims, defending under the Federal Tort Claims Act. ${ }^{272}$ Standing in the shoes of the vaccine makers and all program participants ${ }^{273}$ the government agreed that

(2)(A) The United States shall be liable with respect to claims submitted after September 30, 1976 for personal injury or death arising out of the administration of swine flu vaccine under the swine

270. Government Accountability Office, Report B-164031(5), 58 Comp. Gen. 321 (1979) (reporting on the Swine Flu immunization effort) [hereinafter GAO].

271. Public Law 94-380 amended Section 317 of the Public Health Service Act (42 U.S.C. $247 \mathrm{~b}$ ). The statute was repealed by Public Law 95-626, $\S 202,92$ Stat. 3574 (1978), 42 U.S.C. $\$ 247 \mathrm{~b}$ (1978). See National Swine Flu Immunization Program of 1976, Pub. L. No. 94-380, 90 Stat. 1113 (1976).

272. The FTCA grants original jurisdiction to the District Courts, and 28 U.S.C. $\$ 2674$ provided that the United States shall be liable, respecting the provisions of this title relating to tort claims, in the same manner and to the same extent as a private individual under like circumstances, but shall not be liable for interest prior to judgment or for punitive damages. If, however, in any case wherein death was caused, the law of the place where the act or omission complained of occurred provides, or has been construed to provide, for damages only punitive in nature, the United States shall be liable for actual or compensatory damages, measured by the pecuniary injuries resulting from such death to the persons respectively, for whose benefit the action was brought, in lieu thereof. With respect to any claim under this chapter [28 U.S.C. $\S \S 2671$ et seq.], the United States shall be entitled to assert any defense based upon judicial or legislative immunity which otherwise would have been available to the employee of the United States whose act or omission gave rise to the claim, as well as any other defenses to which the United States is entitled. See Federal Torts Claims Act, 28 U.S.C. § 1346(b) (2007)

273. The National Swine Flu Immunization Program of 1976 states "(B) For purposes of this subsection, the term 'program participant' as to any particular claim means the manufacturer or distributor of the swine flu vaccine used in an inoculation under the swine flu program, the public or private agency or organization that provided an inoculation under the swine flu program without charge for such vaccine or its administration and in compliance with the informed consent form and procedures requirements prescribed pursuant to subparagraph (F) of paragraph (1) of this subsection, and the medical and other health personnel who provided or assisted in providing an inoculation under the swine flu program without charge for such vaccine or its administration and in compliance with such informed consent form and procedures requirements." See National Swine Flu Immunization Program of 1976, Pub. L. No. 94380,90 Stat. 1113 (1976). 
flu program and based upon the act or omission of a program participant in the same manner and to the same extent as the United States would be liable in any other action brought against it under such section 1346 ( b) and chapter 171, except that

(I) the liability of the United States arising out of the act or omission of a program participant may be based on any theory of liability that would govern an action against such program participant under the law of the place where the act or omission occurred, including negligence, strict liability in tort, and breach of warranty. ${ }^{274}$

Little risk was expected when the program began. But the Swine flu vaccine was designed to address a major antigenic switch in the structure of the influenza virus, and with such change came the possibility of new complications of inoculation caused by the new vaccine. In the five years before 1976, some 70 million flu shots had been administered. Only twenty lawsuits alleging adverse effects had been filed, and the largest settlement had been for $\$ 26,000 .{ }^{275}$ Liability became a major issue when the paralytic Guillain-Barre disease unexpectedly appeared to be associated with the new vaccine. Ultimately, in 13 years of litigation, the government paid $\$ 90$ million in settlement of 5,800 claims for complications of the vaccine. ${ }^{276}$ Defense costs were doubtless substantial, although the GAO found insufficient data to calculate the costs. ${ }^{277}$

On June 19, 1978, though there was little evidence that Guillain Barre syndrome should have been anticipated, the Secretary of the Department of Health, Education, and Welfare, Joseph Califano, announced that claimants would not need to establish negligence in order to recover. This allowed recovery for those who could prove that they suffered from Guillain-Barre soon after vaccination. A principal reason for this decision was that the consent form, prepared by the government for this program, did not warn consumers about a possible risk of developing Guillain-Barre syndrome. ${ }^{278}$

274. The National Swine Flu Immunization Program Act amends Section 317 of the Public Health Service Act (42 U.S.C. 247(b). See id.

275. SILVERSTEIN, supra note 268 , at 62 .

276. $\$ 55$ million worth of coverage above a self-insured amount of $\$ 2.5$ million against such claims to each manufacturer. (The government paid the insurance premiums and advanced the $\$ 2.5$ million for self insurance to each of the manufacturers. These advances were returned to the government in 1985.) Charles F. Hagan, Vaccine Compensation Schemes, 45 FoOd DRUG CosM. L.J. 477, 478 (1990).

277. GAO, supra note 270 , at 321 .

278. The following matters were discussed by the Court of Appeals in Unthank v. United States, 732 F.2d 1517, 1520 (10th Cir. 1984). First, the appellate court, along 
Although the government elected to pay GBS claims, it is doubtful that the claims would have been paid if contemporary product liability law applied. The products apparently met all specifications and no case suggests there was any defect that caused the unexpected occurrences. Epidemiological evidence before the vaccination program did not predict the hazard, though it is now recognized as a rare complication. ${ }^{279}$ But given the history of flu vaccine safety and the intensity and character of the government's public relations campaign for its intended vaccination of every man, woman, and child, ${ }^{280}$ liability in the form of the reasonable expectations of the consumer test may well have entitled vaccinees to recovery. Such liability would best be understood as warranty-based, grounded on the broad assurances of product safety. ${ }^{281}$

with the trial court, was impressed with the statement of Congressman Paul G. Rogers of Florida, stating "We have asked the drug companies to produce this vaccine. We have told them how to do it. We have told them the dosage we want, what strength. We gave them the specifications because we are the only buyers, the Government of the United States. This is not the usual process of going out and selling. But if someone is hurt, we think people ought to have a remedy." Unthank v. United States II, 732 F.2d at 1520 (quoting Unthank v. United States I, 533 F. Supp. 703, 719 (1982)) (emphasis added). Second, the appellate court stated that

[t]he trial court also accurately noted that in response to the outbreak of GBS, then Secretary of Health, Education and Welfare, Joseph A. Califano, Jr., responded to the difficulties experienced after the administration of the program and the eruption of litigation. He declared that with respect to those alleging GBS, the policy of the government was to provide compensation to all who contracted GBS from the swine flu vaccine. Secretary Califano stated that those who contract GBS: [w]ill not need to prove negligence by Federal workers or others in the Swine Flu Program as required by Federal law and the law in many states. Instead claimants in most cases need to show only that they in fact developed Guillain-Barre as a result of a Swine Flu vaccination and suffered the alleged damage as a result of that condition.

See id. Finally, the appellate court noted that the Secretary gave two reasons for this policy:

(1) First, the informed consent form ... did not warn individuals that there was a one in one hundred thousand risk that a person receiving a flu shot would contract Guillain-Barre and that one in every two million would die from the condition. ... (2) Second, in the Swine Flu program, the Federal Government, in an unprecedented effort, actively urged millions of Americans to get flu vaccination shots and funded the nationwide campaign. Thus we have decided to provide just compensation for those who contracted Guillain-Barre as a result of the Swine Flu program rather than force many individuals to prove government negligence in protracted proceedings.

See id. (emphasis added).

279. See MEllo AND BRENNAN, supra note 242, at 17-18.

280. SilversteIN, supra note 268, at 84-86.

281. See RESTATEMENT (THIRD) OF TORTS $\S 1$ (1998) (discussing the origins of modern strict product liability law as the merger of tort and contract concepts of warranty); see id. $\S 3$ (discussing the malfunction doctrine--that one can infer the existence of a defect from the malfunctioning of a familiar object-such as the new car the steering mechanism of which fails shortly after purchase). 
As Silverstein reports, the CDC, the Advisory Committee on Immigration Practices (ACIP), the National Institute of Allergies and Infectious Disease, and the FDA Bureau of Biologics found in the clinical trials a rate of adverse reactions essentially the same as that of the control group that received placebo. But the trial was not without flaws and the program not without critics.

Clinical trials had gone generally well, but the planned dose of the vaccine was effective in only half of young adults who had not been primed by natural exposure to influenza. None of the viruses tested was effective at safe doses in children aged 3 to 10 , a prime source of spread of disease. Program planners could elect a higher more dangerous dose or a second "booster" shot. Dissenting voices-like Dr. Sidney Wolfe, now of Public Citizen (then the Health Research Group), and J. Anthony Morris, a dissenting research virologist at the Bureau of Biologicsopposed the program. Some, like Dr. Martin Goldfield of the New Jersey Department of Health, called for stockpiling rather than immunization. But polio pioneers Jonas Salk and Albert Sabin, who agreed on little else, enthusiastically endorsed the mass immunization campaign. They stood by the President's side when he announced the program. $^{282}$

The program had other problems-including doubts about the effectiveness of the surveillance program for adverse effects-an issue that is with us today, despite calls after the Swine flu Campaign to study improvements of the system of adverse event reporting and measures of program effectiveness. ${ }^{283}$ The unity would be short lived, as Sabin came to endorse stockpiling rather than immunization-a contrast with his stance on polio vaccine where he justified the risks of his oral live attenuated-virus vaccine against the risk-free but possibly less effective Salk injected killed virus vaccine. ${ }^{284}$

Looking back at the program-its costs, failures and successes-it is fair to ask if the swine flu campaigns were best understood as product liability claims in which the government absorbed liability simply as an insurer of manufacturers of defective products, or if the liability was properly the government's own. Against manufacturer liability and for public liability are that;

- there appear to have been no manufacturing defects,

- the vaccine type (a killed virus) was specified by the government,

282. SilverSTEIN, supra note 268 , at $84-86$.

283. Id. at 47-49.

284. Government Accountability Office, Report B-198648, 58 Comp. Gen. 321 (1980). 
which exercised broad control of the program,

- the campaign to vaccinate the entire population on an uncertain predictive foundation-was the government's own precautionary public health plan, not the product of a marketing scheme for a product of unproven merit

- the failure to warn of GBS appears not to have been negligentbased on previous experience with influenza vaccination, and given that the conventional small-size of the clinical trial sample is unlikely to turn up an effect as infrequent as GBS's $8.3 /$ million vaccinees/ month.

In the end, the government recovered its deposit for the deductibles and made no claims against the manufacturers' insurers. This does not appear to be due to soft-headedness or to pro-big-business bias, or to government ambivalence about the tort system. Rather it was grounded in Secretary Califano's 1978 executive decision that achievement of the government's goal of effective prevention of an influenza pandemic required recognition of the claims of those who suffered the unexpected injury of Guillain Barre Syndrome. He decided that burden properly belonged with government - as a matter of retention of public trust, at least, if not of product liability law. ${ }^{285}$

In the swine flu cases, the United States accepted responsibility for Guillain Barre Syndrome cases, for the risks of paralytic injury posed by the decision to inoculate virtually the entire population. ${ }^{286}$ But only in the GBS cases did the government concede liability. In every other case, liability was contested. And as time went on, courts in the 1980's came to decisively reject strict liability where the harm suffered could not have been foreseen. ${ }^{287}$ They rejected decisions that rejected the "state of the art" defense such as the New Jersey asbestos case Beshada v. Johns Manville, ${ }^{288}$ and embraced the essentially negligence-based characterization of product liability that dominates courts' practice today. ${ }^{289}$ Swine Flu Act claims were denied for illnesses that were not recognized as complications at the time the Swine Flu vaccine was administered and which were therefore not a complication with which a

285. See id.; see generally SILVERSTEIN, supra note 268.

286. See Charles F. Hagan, Vaccine Compensation Schemes, 45 Food Drug Cosm. L.J. 477, 478 (1990).

287. See Brazzel v. United States, 880 F.2d 84 (8th. Cir. 1998).

288. Beshada v. Johns-Manville Prods. Corp., 90 N.J. 191, 196 (1982). Beshada itself was promptly limited to its asbestos-based facts in Feldman v. Lederle Laboratories, 97 N.J. 429 (1984).

289. REsTATEMENT (THIRD) OF TORTS $§ 2$, cmt. d, f. (1998). 
duty to warn could be imposed under the "state of the art" defenses which required proof that the complication was foreseeable. ${ }^{290}$

In the 1970's and early 1980's many embraced the so-called WadeKeeton rule, which imposed on defendants knowledge of the harmful propensities which a product was shown to have at time of trial, not at the time of production. ${ }^{291}$ This was in tension with the foundational document of the product liability movement-the Restatement 2d's $\S 402 \mathrm{~A}$, which in "comment $\mathrm{k}$ " declared that a useful but unavoidably unsafe product such as the rabies vaccine was not defective so long as it contained adequate warnings to the user. The obligation to warn implied that available knowledge was sufficient to identify the risk. Despite the absence of evidence of lack of foreseeability of paralytic Guillaine Barre Syndrome, the government conceded liability. ${ }^{292}$ The litigation centered on matters of fact-whether the claimant suffered from GBS and whether her infirmities were caused by the vaccine. ${ }^{293}$

But where other maladies were alleged, plaintiffs had to prove to increasingly skeptical courts that the product was defective-that the dangers had been knowable but had not been made known. Thus plaintiff failed in Freeman v. United States, ${ }^{294}$ where Texas law was found to require foreseeability of injury, which plaintiff had not shown, for adhesive capsulitis alleged to have been caused by swine flu vaccination. Similarly in Brasil v. U.S., the Court of Appeals held that Iowa law barred recovery for myalgia by a swine flu recipient because the duty to warn did not extend to unforeseeable risks posed by a product. $^{295}$

B. Hard Sell: The Federal Tort Claims Act-An Independent Basis for Tort Liability of the United States Based on its Failure to Assure Informed Consent

The stance of Congressman Rogers and Secretary Califano regarding $\mathrm{GBS}^{296}$ should not be understood as anomalous as it might appear at first blush. Rather, it demonstrates recognition that there was

290. See Brazzell, infra note 295.

291. Wade Keeton, Products Liability-Inadequacy of Information, 48 TEX. L. REV. $398,407-08$ (1970) ("The imputation of knowledge is a legal fiction. It is another way of saying that for purposes of strict liability the defendant's knowledge of the danger is irrelevant.").

292. Charles F. Hagan, Vaccine Compensation Systems, 45 Food Drug. CoSM. L.J. 477,478 (1990).

293. See Manko v. United States, 830 F.2d 831, 834 (8th Cir. 1987) (stating that, in swine flu vaccine/GBS cases, only causation and damages are an issue).

294. See Freeman v. United States, 704 F.2d 154, 159 (5th Cir. 1983).

295. See Brazzell v. United States, 880 F.2d 84, 87 (8th Cir. 1989).

296. See Unthank II, 732 F.2d at 1520. 
an independent basis for liability against the United States based on the hard sell that was adopted in order to accomplish the presidentiallyembraced goal of inoculating every American.

The Swine Flu case, Petty v. United States, reminds us that the conduct of the United States itself is subject to scrutiny under the Federal Tort Claims Act-which looks to state tort law for principles of liability. Petty is not a GBS case, but rather a "serum sickness" case. The case demonstrates that an FTCA mass inoculation claim against government itself can be competently handled by ordinary tort principles derived from state law. Petty shows the vigor of the tort principle of civil recourse in such circumstances against a wrongdoer-even when that wrongdoer is a governmental agency. ${ }^{297}$

The swine flu cases, like the U.K. hepatitis C-contaminated blood cases discussed below, demonstrate that pandemic and epidemic countermeasure cases can be competently handled by ordinary principles of tort liability as expressed in the Federal Tort Claims Act, which makes the United States liable to the same extent as a private person for nondiscretionary acts.

The Swine Flu Act placed the United States in the shoes of the vaccine manufacturers and administrators, exposing it to claims on the same bases as the manufacturers would have been-negligence, strict liability, or breach of warranty. ${ }^{298}$ But there was another basis for liability-and that was not derivative or vicarious. Rather, the negligence was that of the United States itself. In Petty the Eighth Circuit affirmed the finding of the District Court for the Northern District of Iowa that the United States itself had been negligent--because it had engaged in a "hard sell" of the Swine Flu vaccine. In order to achieve the government's presidentially declared goal of inoculating every man, woman, and child in the country, the public health authorities had deliberately downplayed risks. ${ }^{299}$

The Swine Flu Act directed that an informed consent form be developed. But the form was singularly uninformative. ${ }^{300}$ It was no

\footnotetext{
297. See Petty v. United States, 740 F.2d 1428 (8th Cir. 1984).

298. See Manko, 830 F.2d at 834.

299. See Petty, 740 F.2d at 1436.

300. The waming provided to Petty reads as follows:

IMPORTANT INFORMATION

ABOUT SWINE INFLUENZA

(FLU) VACCINE

(MONOVALENT)

July 15,1976

People with fever should delay getting vaccinated until the fever is gone.

People who have received another type of vaccine in the past 14 days should consult a physician before taking the flu vaccine.

If you have any questions about flu or flu vaccine, please ask.
} 
accident. The District Court had found that the government's "hardsell" approach to immunization had the natural effect of firmly planting within the recipient's mind the imperative need for receiving the shot. The approach taken by those charged with the administration of this program had the "distinct effect of de-emphasizing the importance of making individual determinations as to the advisability of undergoing the risks of immunization." This, it found was incompatible with the Iowa law regarding informed consent- to which the Federal Tort Claims Act bound federal agents. ${ }^{301}$

The Court of Appeals concurred. It observed:

Dr. Hattwick, Director of the National Influenza Immunization Program, Surveillance and Assessment Center, and on the Center for Disease Control staff of the Bureau of Epidemiology, testified that phraseology decisions were made "to encourage participation." Because those in charge were clearly aware of the specific neurological risks, it was Dr. Hattwick's assessment that they must have determined that it was more prudent not to mention or stress these risks. He testified that more specificity could have been confusing, by which he meant that participation would have been hampered. Dr. Katz, a Professor of Law and Psychiatry at Yale University, also testified that the warning was an attempt to induce participation and was inadequate to enable recipients to render an informed consent. On the basis of this testimony, the court could find that under Iowa law, the government's information form inadequately warned the specific, known risk of serum sickness. ${ }^{302}$

The District Court had explained that

Under Iowa law, the Secretary of Health, Education and Welfare, in conjunction with the Center for Disease Control and the Bureau of Biologics, had a duty to warn prospective recipients of the swine flu vaccination of all reasonably foreseeable dangers.

A duty to warn depends on superior knowledge and is said to exist when one may reasonably foresee danger of injury or damage to one less knowledgeable unless adequate warning of danger is given. It is this reasonable foreseeability which triggers the obligation to warn, which must be determined by the circumstances of each case. ${ }^{303}$

We see in Petty the strength of common law principles of liability and recourse encompassed by the Federal Tort Claims Act. The battle

Id. at 1436 .

301. Petty v. U.S., 592 F. Supp. 687 (N.D. Iowa 1983).

302. Petty, 740 F.2d at 1436 (emphasis added).

303. Lakatosh v. Diamond Alkali Co., 208 N.W. 2d 910, 913 (Iowa 1973). 
ground will often be over where to draw the line on the discretionary/ministerial function discretion. But in Petty, the Court of Appeals for the $8^{\text {th }}$ Circuit suggests that it will not be drawn so as to preempt the basic principles of self-determination embraced by state tort law in Iowa-and throughout the country. ${ }^{304}$

How informative the government must be will be founded on ordinary principles of tort law-drawn from medical malpractice and product liability law which has been highly elaborated by courts around the country. Of course that will mean that there is not uniformity-thus we have the contrast between states like New Jersey which adopt a rebuttable presumption that compliance with FDA labeling is sufficient, and Michigan which establishes a conclusive presumption-compliance with FDA approved labeling is a complete defense in a failure to warn case. ${ }^{305}$

The liability of the United States was properly limited, and the integrity of the system of civil recourse preserved in the Swine Flu Act. The suppliers insurance premiums were not to indemnify and defend against injured swine flu vaccinees. For that it was the treasury of the United States which was exposed. ${ }^{306}$ The manufacturers were insured against the government's statutory right of subrogation for negligence or breach of contract by the vaccine manufacturers, who were to produce the stockpile. ${ }^{307}$ The underwriting difficulties for the swine flu influenza vaccine were apparent: the product was new, having been adapted to the new virus, and the intended to be universal. Pricing the product, including its projected liability costs, was obviously difficult. The government was the sole purchaser. It would determine the cost. And part of that cost was properly determined to be the costs of selfinsurance. ${ }^{308}$

By accepting all liability (except for contract breach and mismanufacture) the government placed itself in a posture which invited the trust of the citizenry which it asked to take a risk, individually usually quite low, but which benefited others and the public as a whole. By being vaccinated each person, knowingly or not, contributed to the welfare of others when he or she took the risk of being vaccinated.

In the circumstances of the Swine flu campaign the legitimate

304. Id.

305. Rowe v. Hoffman LaRoche, 2007 N.J. LEXIS 334; Alli v. Eli Lilly \& Co., 854 N.E.2d 372 (Ind. Ct. App. 2006) (discussing differences between New Jersey, Indiana, and Michigan law regarding effect of evidence of compliance with FDA labeling provisions).

306. Lakatosh v. Diamond Alkali Co., 208 N.W. 2d 910, 913 (Iowa 1973).

307. Id.

308. SilversteIN, passim supra note 268 
expectation of the consumer was that the product was safe, certainly that it did not present the risk, and the consumer was not being asked to assume the risk, of a paralytic condition. In this instance, the Department of Health, Education, and Welfare (as it was then known) decided that the consequence of lack of knowledge of the scientific community was for the government to bear, as its undertaking imposed that risk upon the public.

We thus see in the Swine Flu campaign that the Federal Tort Claims Act retains vitality and that it incorporates the flexibility of underlying state common law and thus captures even the force of the consumer expectation test-which is, as Mark Geistfeld has argued, compatible with the general risk utility approach of product liability law because the risk utility test expresses what the consumer is reasonably entitled to expect. $^{309}$

Looking back at the Swine flu experience we can also ask whether the liability imposed is properly described as tort liability or social insurance. It was in fact both. Acceptance of the claims of those who suffered from Guillain Barre Syndrome may be understood as a public health driven incentive, a form of social insurance or as tort liability payments due to unreasonable minimization of risk in the hard-sell government campaign. But those who suffered from injuries, the risk of which there was not adequate warning, though current capability permitted it, were victims of tortious conduct who recovered in tort. The United States, however, did not offer an incentive to join in a public health measure. That innovation came with the National Childhood Vaccine Compensation Act. ${ }^{310}$

Under the Bioshield Act, the development of the strategic national stockpiles will make the United States not only purchaser and distributor but also designer of vaccines and medications stockpiled for use in large scale emergencies. ${ }^{311}$ The Swine Flu Act cases show us that the government's direct liability as distributor and as the provider for information to users will make it rather than manufacturers the prime defendant. Manufacturing defects will be the subject of breach of contract actions by government against manufacturers, if PREPA is not repealed.

The government itself will be liable if the product distributed does not comply with its own specifications. Design defect claims may be barred if such choices are seen as discretionary. But since the adequacy of warnings is the main thrust of drug product liability litigation, the

309. Mark A. Geistfeld, Principles of Products liability (2006).

310. Diamond Alkali Co., 208 N.W. 2d at 913 (Iowa 1973).

311. Id. 
possible loss of design defect claims for stockpiled products will have little effect, since for drugs and vaccines the candle is generally with the warnings game. ${ }^{312}$ The Federal Tort Claims Act stands as a bulwark of tort and makes the common law of tort the governing standard for any epidemic of adverse effects which arises within the epidemic for which drugs, vaccines, and devices in the national stockpile are deployed.

\section{Bad Blood in Britain: What Is a Citizen Entitled to Expect About Drug, Vaccine and Biological Product Safety?}

The Swine Flu cases [the GBS special case aside], like product liability law generally, embraced a requirement that the adverse effects must be knowable to impose a duty to warn. There is no doubt that is a bedrock principle. But Petty makes clear that manner of presentation matters, and that through the FTCA ordinary negligence liability against government itself remains the law, despite the chipping away of the bases for liability against private manufacturers presented by the Public Readiness Act and other measures. In the British contaminated blood cases, the National Blood Authority was found to have been tardy in adopting a test for hepatitis $\mathrm{C}$ contamination. We see in that case an instructive model for direct government liability under the tort claims act if an available safer vaccine design is not adopted (e.g. a failure-as with polio vaccine-to switch from oral live-virus to safer injected killed virus for two decades after bio-equivalency of enhanced killed virus vaccine had been established). Along with Petty, the blood cases show us of the vitality and importance of tort actions against government when fault is not derivative, but rather that of government itself.

When Chiron Corporation developed a new test that could determine the presence of hepatitis $\mathrm{C}$ anti-bodies in donated blood, the U.S. and Japan adopted the new test as a norm almost immediately. Chiron obtained its export license in November 1989. But, unlike the U.S. and Japan, which adopted the test quickly, the British National Blood Authority dallied over a year before requiring the test in January 1991. Patients infected in the interim sued-and prevailed. ${ }^{313}$

How safe does the consumer have a right to expect a drug, vaccine, or medical device to be? It was put by Judge Michael Burton in the English hepatitis $\mathrm{C}$ contaminated blood cases:

"the question is what the legitimate expectation is of persons generally, i.e., what is legitimately to be expected, arrived at

312. David G. OWEN, HANDBOOK OF PRODUCTS Liability, § 9.6 (2004).

313. A and Others v. National Blood Authority, QB [2001] 3 All ER 289. 
objectively." 314 That is, we determine not what the consumer actually expects but what is the reasonable entitlement of the consumer. For that the circumstances are to be examined, in classic negligence manner.

Burton's handling of the contaminated blood cases is more conductcentered and less wooden than our product liability case analyses often are. His approach is an apt one for the swine flu campaign and for other emergency-driven governmental measures. Like the GBS cases, the U.K. contaminated blood cases suggest that government-driven emergent health campaigns, which entwine products and prudential public health judgments, are best seen not simply as product liability actions; but rather as policy-driven governmental operations for which tort liability principles are appropriately applied.

The British cases centered on the conduct of the public health authorities. The action was brought not in common law negligence, but under the Consumer Protection Act 1987, which implemented European Union Council Directive (EEC) $85 / 374$ (on the approximation of the laws, regulations and administrative provisions of the member states concerning liability for defective products). ${ }^{315}$ Examining whether the National Blood Authority ${ }^{316}$ was to be held liable for tardiness in implementing the recently available test for hepatitis $\mathrm{C}$ infection contamination of donated blood, Burton tested the NBA's conduct in light of the circumstances:

(I) Presentation, i.e. the way in which the product is presented, e.g. warnings and price; (ii) The use to which the product could reasonably be expected to be put, e.g.: (a) if the product is not a familiar or usual one, such as a scrid, it will be necessary to find out what its expected or foreseeable use is; (b) if it is expected and required to be dangerous in respect of its expected use, e.g. a gun, then complaint cannot be made of that dangerousness; but complaint could still be made of a different dangerousness, such as if it exploded on the trigger being pulled; and [c] if it is not expected to be dangerous in respect of its expected use, but the use to which it is put is unexpected, then it may not be defective; (iii) The time when the product is circulated, for example when the product is out of date or stale. $^{317}$

314. A and Others, at $\S 31$ (emphasis added).

315. See $A$ and others, $\uparrow 2$.

316. The National Blood Authority is a public authority which oversees the collection and deployment of blood resources through out the United Kingdom. Unlike 47 U.S. states the U.K. has no blood-shield statute in the U.K. Ordinary principles of product liability and consumer protection law apply to its activities.

317. A and Others, at $\S 31$ (emphasis added). 
Burton's approach fits the evaluation of liability in a policy-driven national campaign such as the Swine Flu, smallpox, or future government-led mass vaccination efforts campaign. In the Swine Flu campaign, the urgency was to inoculate the entire population in time for the winter flu season. Such an effort places a premium on preparation and on wide public cooperation-like that achieved in 1947 when the City Department of Health vaccinated six million New Yorkers in two weeks. Presentation of the Swine Flu campaign was driven by the need to achieve so-called "herd immunity." That concept sees each successful vaccinee as an obstacle to spread of the disease. ${ }^{318}$ Maximization of participation is a means of serving not only the individual but also of protecting others. ${ }^{319}$ A public good is served by each person who accepts the risks of vaccination. The time factor limits the choices of products for government to adopt and places a premium on individual assumption of risk. It is inevitably the case in such circumstance that authorities will be tempted to emphasize the individual benefits and de-emphasize the burdens of vaccination, as we saw in Petty $v$. United States.

Judge Burton approached the problem in this way. Under the Consumer Protection Act:

(t)he onus of proof is upon the claimants to prove the product to be defective. (iv) The question to be resolved is the safety or the degree or level of safety or safeness which persons generally are entitled to expect. The test is not that of an absolute level of safety, nor an absolute liability for any injury caused by the harmful characteristic. (v) In the assessment of that question the expectation is that of persons generally, or the public at large. (vi) The safety is not what is actually expected by the public at large, but what they are entitled to expect. The common ground is that the question is what the legitimate expectation is of persons generally, i.e. what is legitimately to be expected, arrived at objectively.... (vii) The court decides what the public is entitled to expect.... . Such objectively assessed legitimate expectation may accord with actual expectation; but it may be more than the public actually expects, thus imposing a higher standard of safety, or it may be less than the public actually expects. Alternatively the public may have no actual expectation-e.g. in relation to a new product-the word coined in argument for such an imaginary product was a 'scrid.' (viii) There are some products, which have harmful characteristics in whole or in part, about which no complaint can be made." 320

Judge Burton's approach to the government agency's tardy adoption

318. Arthur Allen, For the Good of the Herd, N.Y. Times, Op-Ed, January 25, 2007.

319. See generally PlotKIn SA, MORTIMER EA, VACCINES (2d ed.1994).

320. $A$ and Others at $\S 31$ (emphasis added). 
of a blood safety measure is compatible with our law. In such instances the negligence standard of comment $k$ retains vitality in our state product liability law-and therefore remains the basis for liability against the United States. Where risk is unavoidable the patient is entitled to make an informed choice.

It is doubtless the case that individual freedom can be greatly restricted for public health purposes. Many have urged strong restatement of that authority, such as in the Model State Emergency Health Preparedness Act, which emphasizes that even compulsory vaccination may be necessary in certain circumstances. ${ }^{321}$ But in the Swine Flu program, compulsion was not an element. The presentation of the vaccination program - driven by the desire to vaccinate allunderstandably underscored the safety of the vaccine. But the limitations of clinical trials left safety questions unanswered-a fact omitted from the government's presentation to the public. Much more emphasized was the need for vaccination and the low rate and minor nature of complications - that only $2 \%$ of adults in trials developed a low grade fever $\left(<102^{\circ} \mathrm{F}\right)$ or other mild reaction-the same as those who received a placebo. Newspapers embraced the message with an $88 \%$ editorial approval rate for the campaign. ${ }^{322}$ Thus we see in both Petty and $A$ and others v. National Blood Authority the aptness of common law tort principles expressed in statutory remedies when government is the actor in public health measures such as stockpiling and distributing blood products and vaccines.

\section{Recap-A Regressive Trend}

Since the establishment of the September 11 Victims Compensation Fund in the honeymoon period of national unity following the catastrophe, the disaster has impelled no similar social insurance measures. Immunity measures have sprouted but benefits extended have been meager-such as for those who volunteered to receive the smallpox vaccine and were taken ill. The countervailing impulse-to limit liability, to immunize product manufacturers and others whose negligence may cause injury - has made limited advances under the flag of the need to induce the production of protective products and the supply of services.

But the system retains enough stability that the basic structural principles remain in place: the costs of injuries due to war and natural disaster lie where they fall but wrongdoers-whether private or governmental actors - are responsible for the harm done by their faulty

321. LAWRENCE A. GoSTIN, ET AL., JAMA (2002).

322. SILVERSTEIN, supra note 268 , at $82-84$. 
conduct in the circumstances. Emergency-actual or contemplated-has been declared to require a shield from the principle of liability for wrongful acts and omissions that have brought harm to others. Thus the non-fault compensation of the September 11 Victims Compensation Fund provided not immunity but an effective pressure release mechanism for parties who foresaw the possibility of huge liability claims against them - such as the airlines.

The impulse to grant immunity has been seen in the smallpox vaccination campaign, specifically in the new rule announced by the FDA declaring its support for preemption of state tort liability for drugs marketed with approved labeling, and in the "declarations" authorized by the Preparedness Act for marketing and use of vaccines, drugs, and medical devices for prevention, mitigation, and cure of emergency or epidemic injuries and illnesses. ${ }^{323}$ [Of course an epidemic is just an increase of disease beyond the normal-and it may present no circumstance that justifies departure from the usual standards of care.] We have also seen the effort of the defense in the Ground Zero respiratory illness cases to win adoption of a broad measure of emergency civil defense immunity from the claims of workers who suffered respiratory injuries incurred during their work on the smoldering ruins of the World Trade Center in New York City.

But we see too that the tort claims of those who opted out of the September 11 fund, the federalized causes of action of the ground zero cleanup workers - based on state substantive law, and the Federal Tort Claims Act itself-are substantial bulwarks of tort law as it has been commonly understood. We see in the Swine Flu experience the importance of the FTCA as remedy for tortious governmental conductparticularly since the most contentious issues are likely to arise from the mass distribution of relatively untested drugs and vaccines from the national stockpiles established by the Bioshield Act of 2004.

The approach taken by the Congress in the Swine Flu Act of 1976 affirms the system of civil recourse..$^{324}$ That measure allowed actions under the FTCA against the United States government itself, and derivatively, standing in the place of manufacturers facing product liability actions. The act provided that

323. See supra Section III B.

324. See Manko v. United States, 830 F.2d 831, 834 (8th Cir. 1987) ("[T]he Swine Flu Act of 1976, Pub. L. 94-380, 90 Stat. 1113, originally codified as 42 U.S.C. $§ 247 \mathrm{~b}(\mathrm{j})$ et seq. ... established a national program of immunization for a disease popularly known as swine flu. In order to induce private companies to manufacture the needed vaccine, the United States stepped into the shoes of the manufacturer . . . and assumed all liability for damages, incorporating as a remedy the provisions of the Federal Tort Claims Act, 28 U.S.C. $\S 1346(b)$.). The United States retained a right of subrogation in the event of negligence by the manufacturers. The right was never exercised. 
the liability of the United States arising out of the act or omission of a [Swine Flu Vaccine] program participant may be based on any theory of liability that would govern an action against such program participant under the law of the place where the act or omission occurred, including negligence, strict liability in tort, and breach of warranty." 325

So, since $9 / 11$, we can identify a broad regressive trend:

1) The no fault victim compensation fund ${ }^{326}$ succeeded in resolving the claims of almost all those who died or were injured in the $9 / 11$ attacks and their immediate aftermath, ${ }^{327}$ with only a handful pursuing the optional tort remedy. But the Fund-a unique, uncapped administrative measure governed by a benevolent overseer $^{328}$ with a tort option was the first response. Other measures with broad liability restrictions and even lower compensatory components have followed.

2) The Smallpox Emergency Personnel Protection Act provided limited, secondary medical, disability, and death benefits to volunteers who acted for public benefit. ${ }^{329}$ The death benefits are patterned on (and are secondary to) the Public Service Officers Benefits Program which pays benefits to families of policemen and firefighters who die in the line of duty. ${ }^{330}$ Congress rejected the option of folding smallpox vaccine-related injuries in the National Childhood Vaccine Injury Compensation Program, ${ }^{331}$ a public health measure which provides an apt model for the smallpox program which was directed to gaining the cooperation of public health volunteers.

3) "Tort reform" limits have been repeatedly embraced, rejecting the objective of requiring wrongdoers to absorb the full cost of their conduct, limiting damages to the available insurance coverage, limiting joint and several liability, failing to provide attorneys fees for prevailing claimants, and barring punitive damages.

4) Causes of action have been federalized and state remedies preempted, as in the ATSSSA, the Safety Act, and the SEPPA which

325. Swine Flu Program Act, P.L. 94-380, 10 Stat 113, § 2 (1976).

326. ATSSA, supra note 23, at $\$ 408$.

327. 21 C.F.R. 104.2 (2007) (Eligibility Determination and Requirements).

328. DILLER, supra note 30 , at 766-767.

329. P.L. 108-20 (2003) (42 U.S.C. § 239, et seq.); 42 C.F.R. 102.1, et seq.; Conk, supra note 181 .

330. 42 U.S.C. 3796, et seq. (2006).

331. National Childhood Vaccine Injury Act of 1986, 42 U.S.C. $\S 300 a a-10$, et seq. (2006). 
preempt state tort law.

5) Emergency acts have been deployed by litigants such as New York City to gain immunity for certain actions. (E.g. SDEA, Stafford Act)

6) Duties of ordinary care have been codified, providing defenses to common law tort actions against medicine and medical device manufacturers (e.g. Emergency Use Act 21 U.S.C. 354; 10 U.S.C. 1107; Project BioShield Act of 2004 - 21 U.S.C.A. \$ 360bbb-3)

7) Virtual immunity has been promised to the producers of products to be deployed in case of disasters, epidemics and pandemics without demonstration of any exigent circumstances justifying the departure from ordinary care.

8) Industrial workers - the much lauded thousands of ground zero clean-up workers with respiratory injury claims-have retained the familiar remedies of the workers compensation, disability pension, and tort systems. Although Congress created a $\$ 350$ million captive insurance company to defend and indemnify the City of New York, workers have confronted contested workers compensation claims and full scale all-out traditional tort defenses, including the not yet resolved issues of state and federal emergency act immunities. But those workers also have the benefit of the provision of the ATSSSA which, though it preempted state remedies chose as the substantive law that of New York State.

The lessons learned regarding worker health and safety are familiar ones: there was inadequate preparation for the disaster-as public health authorities had not established partnerships with agencies outside their field such as police, fire, Coast Guard, and FBI. Such omissions remarkable because the World Trade Center had already been the target of attack-lead to unclear lines of authority, poor risk communication, inadequate protection of workers, lack of chemical exposure standards for residents and workers, failures of building safety and evacuation, and an absence of baseline data for health tracking of the impact of the environmental disaster. ${ }^{332}$ For such wrongs state tort law and the Federal Tort Claims Act remain viable remedies and pillars of the system of civil recourse for tortious injury.

332. See generally David Rosner and Gerald Markowitz, SEPTEMber 11 AND tHe

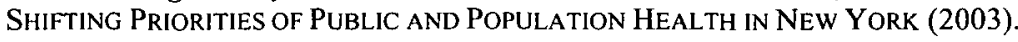




\section{Where Do We Go from Here? Civil Recourse and a Common Vision of Tort Law}

The idea that the civil law provides a remedy for wrongful injury by one person to another is deeply embedded in our law and culture. The principle has constitutional stature, as Prof. John Goldberg has recently elucidated. $^{333}$ The expectation is embedded both in the law of states, and in federal law.

The right-to-remedy clause of the Ohio Constitution, for example, mandates that "every person, for an injury done him in his ... person, *** shall have remedy by due course of law."334 In Louisiana, an intermediate appellate court ${ }^{335}$ has declared that because of inflation Louisiana's $\$ 500,000$ medical malpractice damages cap has so "depreciated" the value of that sum that it violates the state constitution's guarantee of an "adequate remedy" at law. ${ }^{336}$ In Amendment VII, the United States Constitution preserves the right to jury trial shall be preserved in all "suits at common law" in matters in controversy in excess of $\$ 20 .{ }^{337}$ The concept of due process is broad enough, Goldberg suggests, to encompass the right of civil recourse-to take from a wrongdoer that which fairly recompenses the harm done. ${ }^{338}$

William Blackstone's elaboration of the uncodified constitution of English law acknowledges as foundational the customary expectations of Englishmen, a sense of rights, wrongs, and remedies. ${ }^{339}$ If we acknowledge that our common law heritage similarly informs our foundational law, we can say with Blackstone:

In vain would rights be declared, in vain directed to be observed, if there were no method of recovering and asserting those rights, when wrongfully withheld or invaded. This is what we mean properly

333. See infra note 354 .

334. OHIo CONST. art. $1 \S 16$ (1803).

335. State of Lo./Arrington v. ER Physicians Group, 2006 La. App. LEXIS 2164 (2006).

336. LA. CoNST. art 1, $§ 22$ (1974) (providing: "All courts shall be open, and every person shall have an adequate remedy by due process of law and justice, administered without denial, partiality, or unreasonable delay, for injury to him in his person, property, reputation, or other rights.").

337. U.S. CONST. amend. VII ("In suits at common law, where the value in controversy shall exceed twenty dollars, the right of trial by jury shall be preserved, and no fact tried by a jury, shall be otherwise reexamined in any court of the United States, than according to the rules of the common law.").

338. John C.P. Goldberg, The Constitutional Status of Tort Law: Due Process and the Right to a Law for the Redress of Wrongs, 115 YALE L. J. 524 (2006).

339. 1 William Blackstone, Commentaries on the LaWs of England (1976) passim. 
when we speak of the protection of the law. ${ }^{340}$

September 11, 2001 saw the first attack on our capital since the British burned Washington. The emotional impact of the towers' fall and the Pentagon burning may have exceeded Pearl Harbor's. The acceptance of the hyperbolic labeling of the site as Ground Zero conveys the message that $9 / 11$ was a shock that like Pearl Harbor could trigger both solidarity and vengeance. We realized in shock that stepping from the subway to the elevator could be the occasion for the deaths of ourselves and thousands out of the clear blue. Many have asked if traditional constitutional protections need to be modified permitting, for example, warrantless surveillance outside the bounds of current law, or even an emergency constitution recognized. And, unfortunately, many have seen in the catastrophe reason to erode the fundamental principles of responsibility for which the law of torts stands. To stay that course would, I think, be gravely mistaken.

It is almost breath-taking to read, as in the Swine Flu Act and S. 2291, that the United States government accepts responsibility for tort claims based on "under the law of the place where the act or omission occurred, including negligence, strict liability in tort, and breach of warranty."341 We have come to expect instead broad measures to federalize and shrivel tort law like H. R. 5 which passed the House of Representatives in $2005 .^{342}$ The bill is a catalog of the "tort reform agenda"- caps on noneconomic and punitive damages, limits on counsel fees, elimination of joint and several liability, periodic rather than lump sum payment of damages, and the like in medical malpractice and medical product liability cases.

Such anti-tort thrusts and historic anti-tort measures proceed on the assumption that provision of needed products and services is obstructed by tort liability for products like vaccine, blood, and biologics that respond to emergencies or are "unavoidably dangerous." Some argue that drugs as a class are different and cannot be competently handled by

340. Id. at 55-56.

341. Swine Flu Act supra note 325, at $\S(2)(A)(i)$.

342. Congressional Research Service, Report to Congress, H.R. 5, 109th Congress, RS22054- January 18, 2006. The measure, which the House passed without amendment on July 28,2005, "would preempt state law regarding some aspects of medical malpractice liability, and liability for defective medical products, including drugs. It would not, however, preempt any state law that imposes greater procedural or substantive protections for health care providers and health care organizations from liability. In medical malpractice and defective medical products suits, H.R. 5 would, among other things, place caps on noneconomic and punitive damages (but only in states that have not enacted and do not enact caps), eliminate joint and several liability, modify the collateral source rule, limit lawyers' contingent fees, enact a federal statute of limitations, and provide for periodic payment of future damages." 
ordinary principles of tort law. ${ }^{343}$ Others proceed on the basis of urban myths of out of control juries and courts that have been shown to have no basis in fact, as both Professor Thomas Baker and the Rand Institute for Civil Justice have shown decisively regarding one of the favorite targets-medical malpractice claims. ${ }^{344}$

It is my argument that tort law needs re-vitalization and that the revival should be on the basis of traditional doctrinal principles, not on the basis that tort law is a form of "social engineering," as William Prosser once put it; ${ }^{345}$ a means to address the social problem of the costs of accidents, as Guido Calabresi famously put it; ${ }^{346}$ or to achieve efficient wealth-maximizing results through cost-benefit analysis, as Richard Posner and his Benthamite apostles have urged. ${ }^{347}$ Nor is the law of torts a way to fill in the gaps in our social welfare system, or to discipline corporate barons who slight safety-though it may serve those goals. ${ }^{348}$

Rather, tort law should be recognized as a guarantee of the principle of responsibility for one's actions. Determination of liability in tort is a valuable measure and means of achieving civility in civil society. As Professor Stephen Sugarman has recently observed-American liberals

343. See Aaron D. Twerski and James A. Henderson, Jr., Drugs Are Different, 111 YALE L.J. 151 (2001); George W. Conk, The True Test: Alternative Safer Designs for Drugs and Medical Devices, 49 UCLA L. REV. 737 (2002).

344. See generally Thomas Baker, The Medical Malpractice Myth (2005) (Few victims of medical malpractice bring lawsuits. The system is not in crisis due to jury verdicts but would benefit from structural reform of the malpractice insurance industry); Nicholas Pace, et al., Capping Non-economic Awards in Medical Malpractice TRIALS, CALIFORNIA VeRDICTS UNDER MICRA (2004) (caps on non-economic damages have reduced awards to plaintiffs by $30 \%$ with the heaviest burden falling on the most seriously injured).

345. William L. Prosser, Prosser on Torts (2d. ed.) (1955) ( 33 Social Engineering "The law of torts is concerned primarily with the adjustment of the conflicting interests of individuals to achieve a desirable social result ... both for the present and for the future." $\S 4$ Factors affecting tort liability include not only "the weight attached to the particular interest" but also by "other considerations" including "the moral aspects of the defendant's conduct," the "historical development of the law," the "difficulty" of administering the proposed rule, and "possible prevention of future torts").

346. See genereally Guido CALABRESI, THE COSTS OF ACCIDENTS (1970) (strict enterprise liability can reduce the social cost of accidental injury).

347. Richard A. Posner, $A$ Theory of Negligence, 1 J. LEGAL STUD. 29, 32-33 (1972) ("The ordinary negligence rule is designed to encourage actors to act only when the benefits outweigh the costs. Ordinarily, the threat of liability will deter a person from acting if the costs outweigh the benefits because the actor will be forced to pay those costs in a lawsuit; if the benefits outweigh the costs, the actor will proceed knowing that it will not be held liable and will enjoy the benefits. As a result, the optimal outcome is achieved.") (citing Snyder v. American Association of Blood Banks, 144 N.J. 269, 310 (1995) (Garibaldi, J., dissenting)).

348. Carl T. Bogus, Why Law Suits Are Good for America passim (2004) (product liability lawsuits provide a form of corporate discipline). 
have done a flip-flop. Longtime critics of tort and proponents of sociological explanations and structural solutions rather than advocates of punitive measures to control conduct, liberals have become tort's leading defenders. In it they find comfort in the doctrinal principle of personal responsibility for wrongdoing, while conservative critics lodge grievances against the system for inefficiency and randomness and unpredictability. ${ }^{349}$ There lies the seed of resolution of the tort wars of recent years. Focus on doctrinal principles reunites liability rules and remedies.

The thrust of tort reform has not been an attack on principles of personal responsibility, but instead has focused on reducing the costs to repeat players in the system-manufacturers, medical practitioners, liability insurers, government, and the like. ${ }^{350}$ But as the Louisiana appellate court declares in Arrington v. ER Physicians, erosion of remedies can undermine their constitutionally required substance: the provision by government of an adequate remedy for those injured by the wrongful acts of others. ${ }^{351}$

Switching the focus of the tort debate from cost reduction and corporate governance to principles of personal responsibility clarifies the principles and remedies for which we stand. Tort law, along with the right of action by an injured person against a wrongdoer, strengthens the bonds of civility among citizens and between government and citizens. Tort's broad reach expresses not a culture of irresponsibility but rather of accountability, in which all actors are governed by a equivalent standards of conduct, care dictated by capability and circumstance. When responsibility principles are identified as central, we may find greater receptiveness among legislators, and greater judicial willingness to reject arbitrary legislated limits on actions and on remedies. We see support for this in the many state court decisions which have invalidated state damages caps. ${ }^{352}$

349. Stephen D. Sugarman, Ideological Flip-Flop: American Liberals Are Now the Primary Supporters of Tort Law (2007), available at SSRN: http://ssrn.com/ abstract $=925244$.

350. See BURKe, LaWYERS, LAWSUITS, AND LEgal Rights, supra note 28.

351. Arrington v. ER Physicians, $2006 \mathrm{La}$. App. LEXIS 2164 (Inflation has eroded value of $\$ 500,000$ cap on medical malpractice damages from $\$ 500,000$ to $\$ 160,000$. Court voids legislative damages cap because the Supreme Court has said that the Louisiana Medical Malpractice Act must be strictly construed because it grants advantages to special classes in derogation of some rights available to tort victims, and the Louisiana Constitution provides: Article 1, § 22. All courts shall be open, and every person shall have an adequate remedy by due process of law and justice, administered without denial, partiality, or unreasonable delay, for injury to him in his person, property, reputation, or other rights.).

352. Arrington, supra note, at 335 (citing cases in other jurisdictions striking damages caps). 
In recent years, two scholars, John C.P. Goldberg and Benjamin Zipursky, have elaborated the principle that tort law should be understood not as social engineering, ${ }^{353}$ and not as corrective justice (though they are close to that view), but as a system of civil recourse. ${ }^{354}$ By that they mean that torts is about what it appears to be, the exercise of a personal right of action by one who has suffered harm against the wrongdoer who inflicted the harm. Tort law is based on fundamental principles of responsibility familiar across continents and time.

Thus, William Blackstone wrote that "wherever the common law gives a right or prohibits an injury, it also gives a remedy by action, and therefore, wherever a new injury is done, a new method or remedy must be pursued." 355 And the current draft of the revised civil code of the Peoples Republic of China begins, "One who through his fault causes bodily injury or damage to the property of another shall bear tort liability." 356 Measures that grant immunity for faulty conduct run not only against the grain of our tradition, but against the basic principles of civil society which we rightly urge upon others.

Statutory codification can serve the principle well where a statute specifies a guidance rule. A recent example is the enactment of procedures for FDA authorization of emergency use of medicines still under development. That measure comports with the fundamental principle that each of us owes others whom our activities may harm the duty of reasonable care under the circumstances. ${ }^{357}$ But broad pseudoemergency provisions like those of the Public Readiness and Emergency Preparedness Act of 2005 do not.

353. John C.P. Goldberg, Twentieth Century Tort Theory, 91 GEORGETOWN L.J. 513 (2003).

354. Benjamin C. Zipursky, Rights, Wrongs, and Recourse in the Law of Torts, 51 VAND. L. REV. 1 (1998) ("In a civilized society, we are not permitted to "get even"-we are entitled to a private right of action in place of getting even... A private right of action against another person is essentially a response to having been legally wronged by that person, and therefore exists only where the defendant has committed a legal wrong against the plaintiff and thus violated her legal right.").

355. 3 William Blackstone, COMmentaries ON tHE LAWS OF ENGLAND, OF PRIVATE WRONGS, 123 (1768).

356. Civil Code of the Peoples Republic of China, Ch. 8, art. 1 (draft of December 17, 2002), 10 Si Fa (Private Law Review) 277 (2005), trans. George W. Conk.

357. 21 U.S.C. $\S 360 \mathrm{bbb}-3$ (2006) (The Secretary of Health may authorize emergency use of a drug if she finds...."). 
*** 